\title{
CONSERVAÇÃO E REÚSO DE ÁGUA EM INDÚSTRIA DE COSMÉTICOS - ESTUDO DE CASO DA NATURA COSMÉTICOS
}

Dissertação apresentada à Escola

Politécnica da Universidade de São Paulo para obtenção do título de Mestre em

Engenharia

\section{São Paulo}




\section{CONSERVAÇÃO E REÚSO DE ÁGUA EM INDÚSTRIA DE COSMÉTICOS - ESTUDO DE CASO DA NATURA COSMÉTICOS}

Dissertação apresentada à Escola Politécnica da Universidade de São Paulo para obtenção do título de Mestre em Engenharia

Área de Concentração:

Engenharia Hidráulica e Sanitária

Orientador:

Prof. Doutor José Carlos Mierzwa

\section{São Paulo}


Este exemplar foi revisado e alterado em relação à versão original, sob responsabilidade única do autor e com a anuência de seu orientador.

São Paulo, de junho de 2009.

Assinatura do autor

Assinatura do orientador

FICHA CATALOGRÁFICA

Alves, Sebastião Sampaio

Conservação e reúso de água em indústria de cosméticos: estudo de caso da Natura Cosméticos / S.S. Alves. -- ed.rev. -São Paulo, 2009.

$130 \mathrm{p}$.

Dissertação (Mestrado) - Escola Politécnica da Universidade de São Paulo. Departamento de Engenharia Hidráulica e Sanitária.

1.Água (Conservação) 2.Reúso de água 3.Cosméticos I.Universidade de São Paulo. Escola Politécnica. Departamento de Engenharia Hidráulica e Sanitária II.t. 
Aos meus pais, Alzira e José, pelo exemplo de virtude, dedicação e valorização da minha formação, a minha esposa Cristina e aos meus filhos Cíntia e Fernando, pelo amor, companheirismo e compreensão em todos os momentos. 


\section{AGRADECIMENTOS}

Ao Prof. José Carlos Mierzwa pelo apoio, orientação equilibrada, confiança depositada e amizade.

Aos demais professores e funcionários do Departamento de Hidráulica da Escola Politécnica da Universidade de São Paulo e do Centro Internacional de Referência em Reúso de Água, em especial aos Profs. Ivanildo Hespanhol, Roque Piveli e Sidney Seckler.

A Indústria e Comércio de Cosméticos Natura Ltda. - Natura Cosméticos, em nome da Sra. Ângela Pinhati, pela oportunidade e apoio para o desenvolvimento deste trabalho.

Aos demais colegas da Natura que contribuíram das mais diferentes formas, em especial às Sras. Rita Costoya, Gabriela Penkaitis e Simone Egídio, e aos Srs. Rodolfo Santos, Givaldo Santos, Marcos Josmar, Douglas Santos, Marcos Rissato, Célio de Magalhães e Valdeir Cortes. 


\section{RESUMO}

Para a indústria de produtos de higiene e cosméticos o recurso água é de primordial relevância, considerando as quantidades e a qualidade necessárias para a condução dos processos de produção. O agravamento da escassez de água, devido ao crescimento populacional e às atividades industriais, pressionam para a elaboração de leis e normas que restringem o uso da água, elevam os custos para a sua obtenção e impõem maiores controles sobre o tratamento e lançamento de efluentes. Assim, as técnicas de conservação e reúso de água passam a ser elementos diferenciais nos resultados das empresas que as utilizam, além, é claro, do evidente benefício para a sociedade e meio ambiente. Este trabalho tem o objetivo de apresentar um estudo de caso mostrando técnicas utilizadas na conservação e reúso de água no segmento industrial de fabricação de cosméticos. São descritas as dificuldades e limitações existentes, em função das características do processo produtivo e das exigências de qualidade e normas sanitárias. Entretanto, apesar dessas limitações, mostra-se ainda que existem oportunidades para redução dos índices de consumo do recurso água, através de modificações em processos de lavagem de tanques e reatores, controle de perdas, eliminação de desperdícios, conscientização e treinamentos de operadores. Essas ações podem levar a economias substanciais, que podem chegar a até $80 \%$ em alguns dos processos investigados. São ações que podem ser aplicadas em complementação ao programa de conservação existente.

Palavras-chave: Água (Conservação). Reúso de água. Cosméticos. Indústria. 


\section{ABSTRACT}

Water is an essential resource for the manufacturing of personal care products and cosmetics, when account is taken of the amount and quality required for carrying out these production processes. The water scarcity, due to the population growth and expansion of industrial activities, are leading the authorities to draw up laws and regulations to restrict the use of water, raise the costs of its supply and impose greater control over its treatment and the discharge of effluents. Thus, conservation techniques and water reuse are becoming distinct factors in the results of the companies which employ this technology, besides the fact that there are evident benefits to the society and the environment. The purpose of this paper is to discuss a case study which examines the techniques for conserving and reusing water in the manufacturing sector of the cosmetics industry. The difficulties and restrictions on water conservation and reuse are described with regard to the way it is supplied and current quality and sanitation requirements. However, despite the fact that these restrictions are in force, it is also shown that there is still opportunity for reducing the level of consumption of this resource. This includes changes in the way tanks and reactors are cleaned, better control of water loss, cutting waste in water operations, and ensuring that a proper training is given to the operators so that they are made aware of the problems. These measures can also lead to substantial savings, which, it was estimated, reached a level of $80 \%$ in some processes investigated. The findings of this study suggest that there is a need to supplement the conservation program already in practice.

Keywords: Water (Conservation). Water reuse. Cosmetics. Industry. 


\section{SUMÁRIO}

\section{LISTA DE FIGURAS}

\section{LISTA DE TABELAS}

\section{LISTA DE SÍMBOLOS E ABREVIAÇÕES}

\section{RESUMO}

\section{ABSTRACT}

1 INTRODUÇÃO. .1

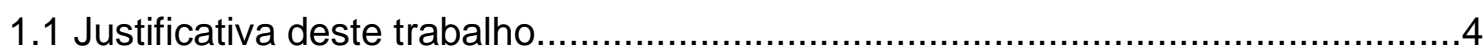

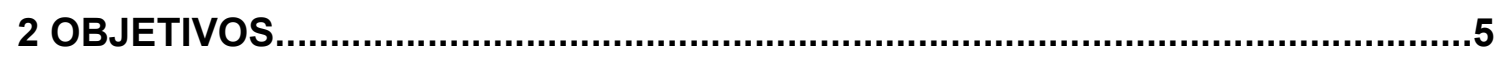

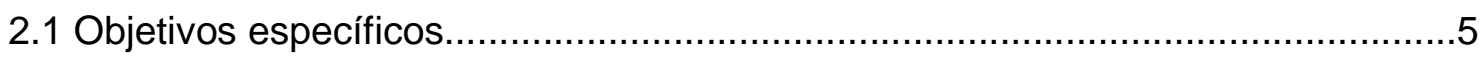

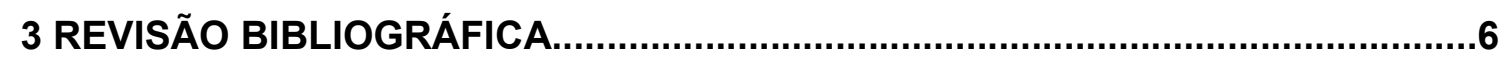

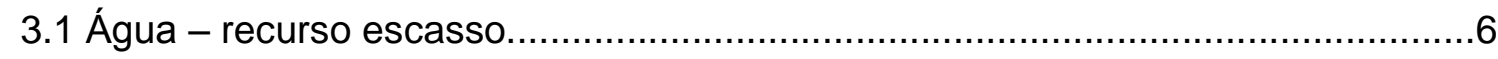

3.2 O gerenciamento dos recursos hídricos.................................................

3.3 A indústria de cosméticos e o uso da água.............................................10

3.4 Meios de obtenção e tratamento da água para fins industriais........................16

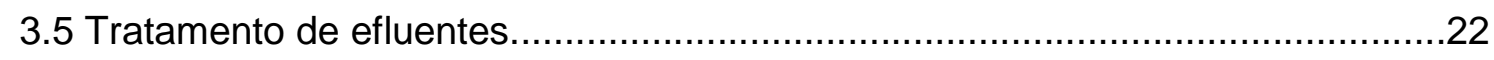

3.6 Conservação e uso racional da água nas indústrias.....................................24

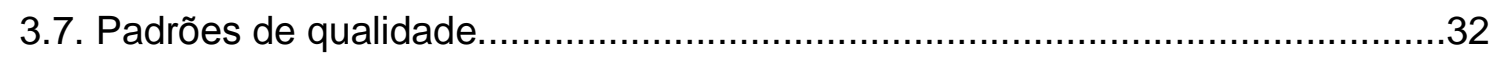

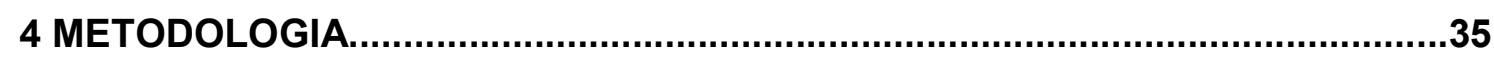


5 INFORMAÇÕES SOBRE A EMPRESA...................................................

5.1. Identificação e informações sobre a empresa.......................................38

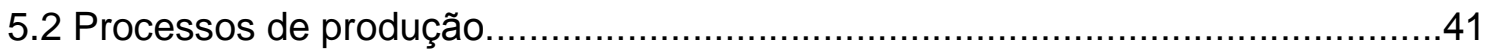

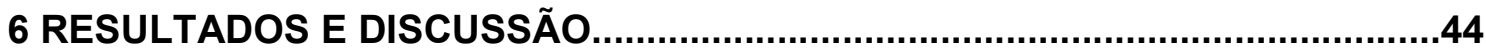

6.1 Avaliação do histórico do consumo de água no setor industrial......................44

6.2 Identificação de fontes de água e tratamento empregado............................46

6.3 Caracterização e padrões de qualidade da água.......................................49

6.4 Sistema de tratamento de efluentes..................................................56

6.5 Levantamento do balanço hídrico................................................... 70

6.6 Identificação dos processos industriais de maior consumo de água...................78

6.7 Considerações sobre as outras possibilidades de conservação de água...........87

6.8 Considerações sobre a possibilidade de reúso da água tratada disponível........98

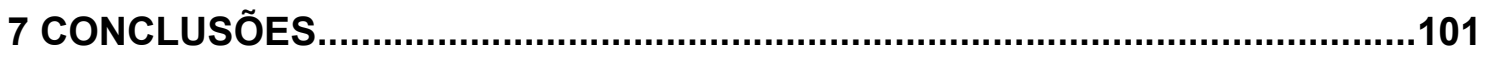

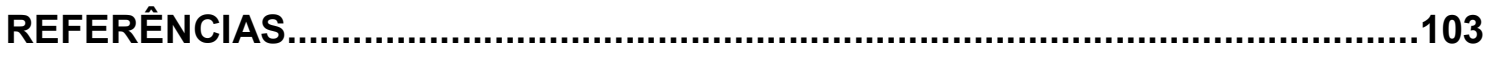




\section{LISTA DE FIGURAS}

Figura 1.1 - Disponibilidade hídrica no estado de São Paulo

Figura 3.1 - Processo de desmineralização por resina de troca iônica

Figura 3.2 - Processo de purificação por osmose reversa

Figura 3.3 - Tipos de reúso

Figura 6.1 - Evolução do consumo de água relativo em L/unidade produzida recalculado

Figura 6.2 - Evolução do consumo de água total em $10^{3} \mathrm{x} \mathrm{m}^{3}$

Figura 6.3 - Crescimento da produção de cosméticos

Figura 6.4 - Crescimento do número de empregados

Figura 6.5 - Diagrama simplificado do sistema de captação, tratamento e reservação de água

Figura 6.6 - Filtro de areia

Figura 6.7 - Usina de $\mathrm{ClO}_{2}$

Figura 6.8 - Diagrama simplificado do sistema de desmineralização de água

Figura 6.9 - Diagrama simplificado do sistema de osmose reversa

Figura 6.10 - Filtros e abrandadores

Figura 6.11 - Módulos de membranas de OR

Figura 6.12 - Painel de controle do sistema de OR

Figura 6.13 - Desinfecção por radiação UV

Figura 6.14 - Fluxograma básico do sistema de tratamento de efluentes 
Figura 6.15 - Sistema de ultrafiltração

Figura 6.16 - Cassete de membranas de ultrafiltração

Figura 6.17 - Sistema de captação de esgotos sanitários a vácuo

Figura 6.18 - Tanques de tratamento físico-químico

Figura 6.19 - Filtros-prensas

Figura 6.20 - Diagrama da recirculação de substrato entre o biorreator e o sistema de ultrafiltração

Figura 6.21 - Diagrama da Estação de Tratamento de Efluentes

Figura 6.22 - Diagrama simplificado da distribuição de águas na empresa

Figura 6.23 - Diagrama do balanço hídrico em toda a unidade Cajamar

Figura 6.24 - Diagrama do balanço hídrico para os setores não industriais

Figura 6.25 - Diagrama do balanço hídrico para os setores industriais

Figura 6.26 - Consumo anual dos diferentes setores da empresa

Figura 6.27 - Reatores de fabricação

Figura 6.28 - Tanques de armazenamento

Figura 6.29 - Agitador impregnado com produto

Figura 6.30 - Tampa impregnada com produto

Figura 6.31 - Sistema de pulverização de detergente especial e do conjunto de agitação de um reator

Figura 6.32 - Foto de hidrômetro 1

Figura 6.33 - Foto de hidrômetro 2 
Figura 6.34 - Diagrama do sistema de limpeza CIP

Figura 6.35 - Vista dos reatores Kromix com sistema CIP 1

Figura 6.36 - Vista dos reatores Kromix com sistema CIP 2

Figura 6.37 - Tanques de reagentes para sistema CIP

Figura 6.38 - Tanques de recirculação do sistema CIP

Figura 6.39 - Torre de refrigeração 1

Figura 6.40 - Torre de refrigeração 2

Figura 6.41 - Chillers do ar condicionado 1

Figura 6.42 - Chillers do ar condicionado 2 


\section{LISTA DE TABELAS}

Tabela 1.1 - Vazões captadas em m³/s no estado de São Paulo e em algumas Unidades de Gerenciamento de Recursos Hídricos entre 2004 e 2007 e projeção para 2015 e 2020

Tabela 3.1 - Principais normas regulatórias para os produtos cosméticos

Tabela 3.2 - Etapas de um tratamento convencional para água potável

Tabela 3.3 - Parâmetros de qualidade para utilização de água purificada

Tabela 4.1 - Lista dos hidrômetros instalados

Tabela 6.1 - Resultado das análises da água potável produzida na ETA no período de julho a outubro de 2008

Tabela 6.2 - Condutividade no processo de mistura de água de rejeito da OR e água extraída do poço artesiano

Tabela 6.3 - Resultado de análise de efluente sanitário

Tabela 6.4 - Resultado de análise de efluente industrial

Tabela 6.5 - Resultado de análise rotineira de efluente tratado

Tabela 6.6 - Lista dos setores da empresa e seus consumos de água

Tabela 6.7 - Lista dos setores industriais e seus consumos de água

Tabela 6.8 - Consumos de água para limpeza e sanitização de reatores

Tabela 6.9 - Volumes totais consumidos na limpeza e sanitização dos reatores

Tabela 6.10 - Consumos de água para limpeza e sanitização de tanques de armazenamento 
Tabela 6.11 - Volumes totais consumidos na limpeza e sanitização de tanques de armazenamento

Tabela 6.12 - Consumo total de água para as operações de limpeza e sanitização na Fábrica 2

Tabela 6.13 - Consumos de água e detergente para limpezas seqüenciais nos reatores $A, B$ e $C$, na Fábrica 2

Tabela 6.14 - Consumo total de água para limpeza e sanitização dos reatores e tanques de armazenamento

Tabela 6.15 - Consumos com limpeza e sanitização com processo manual

Tabela 6.16 - Consumos com limpeza e sanitização com processo CIP

Tabela 6.17 - Economias previstas com limpeza CIP 


\section{LISTA DE SÍMBOLOS E ABREVIAÇÕES}

ANA - Agência Nacional de Águas

ANVISA - Agência Nacional de Vigilância Sanitária

ANVS - Agência Nacional de Vigilância Sanitária

CDPS - Comissão de Política e Desenvolvimento Sustentável

cGMP - current Good Manufactoring Practices

CIP - Cleaning in place

CONAMA - Conselho Nacional do Meio Ambiente

COT - Carbono orgânico total

DBO - Demanda bioquímica de oxigênio

DQO - Demanda química de oxigênio

DAEE - Departamento de Águas e Energia Elétrica

EPA - Environmental Protection Agency

ETA - Estação de tratamento de águas

ETE - Estação de tratamento de esgotos

ISA - Instituto Sócio Ambiental

LAO - Liceu de Artes e Ofícios

O\&G - Óleos e graxas

OMS - Organização mundial de Saúde

ONU - Organização das Nações Unidas 
OR - Osmose reversa

P\&D - Pesquisa e Desenvolvimento (prédio)

NAN - Núcleo de Aprendizagem Natura (prédio)

SNVS - Sistema Nacional de Vigilância Sanitária

STD - Sólidos totais dissolvidos

UGRHI - Unidade de gerenciamento de recursos hídricos

UV - Ultravioleta (radiação)

WCED - World Commission on Environment and Development

WHO - World Health Organization 


\section{INTRODUÇÃO}

O conceito de desenvolvimento sustentável, conforme definido no relatório "Nosso Futuro Comum" da Comissão Mundial sobre Meio Ambiente e Desenvolvimento (WCED, 1987), é quando se provê as necessidades da geração atual sem comprometer a habilidade das futuras gerações proverem as suas. Com isso, podese dizer que todas as relações entre o Homem e a natureza tornam-se fatores importantes, pois a utilização dos recursos naturais pelo Homem não deve alterar as condições de equilíbrio ambiental no planeta.

A importância de um recurso para os seres humanos leva em conta que a sua utilização está relacionada aos fatores tecnologia, economia e meio ambiente. Um recurso natural somente pode assim ser considerado, se houver tecnologias para sua obtenção, transformação e utilização e se isto for economicamente viável.

O fator ambiental somente passou a ser levado em conta nas últimas décadas, quando começou a se ter consciência de que a exploração de um recurso, o seu processamento e a sua utilização não deveriam causar danos ao meio ambiente, em seu mais amplo sentido.

Mesmo um recurso renovável pode passar a ser não renovável caso a taxa de sua utilização supere a máxima capacidade de sustentação do sistema através de seus ciclos (HARDIN, 1968). O ciclo hidrológico da água garante a sua renovação porém, infelizmente, não garante sua abundância em muitas regiões do planeta.

A água é um fator limitante para o desenvolvimento sustentável, uma vez que a vida não se desenvolve sem ela e, da mesma forma, é importante para as atividades industriais e para a geração de energia (REBOUÇAS et al., 2006).

Muitas vezes a água é o fator preponderante para determinar a viabilidade ou não de um empreendimento, sem contar sua necessária aplicação na manutenção das condições de conforto e higiene dos empregados do empreendimento.

Essa viabilidade está diretamente associada à disponibilidade desse recurso na quantidade e qualidade exigidas pelo processo industrial. Isso exige, na maioria das 
vezes, a busca por fontes de abastecimento adequadas ou que as águas disponíveis passem por tratamentos adequados que garantam os níveis de qualidade necessários aos processos de produção.

Portanto um dos maiores desafios que deve ser enfrentado para alcançar o desenvolvimento sustentável é a minimização dos efeitos da escassez da água (sazonal e regional) e da poluição, que altera sua qualidade, e a busca de processos que levem à conservação do recurso e ao consumo mais racional ou mesmo reúso.

O Brasil possui aproximadamente $12 \%$ da água doce do planeta, mas sua distribuição é bastante heterogênea. Na Região Norte, a região hidrográfica Amazônica detém cerca de 74 \% dos recursos hídricos superficiais nacionais, para uma população de cerca de 7,0 \%, enquanto que as Região Sudeste detém apenas $6,0 \%$ desse recurso, porém com uma população de 42,6 \% (ANA, 2009).

A Tabela 1.1 mostra o crescimento do consumo de água no Estado de São Paulo.

Tabela 1.1 - Vazões captadas em $\mathrm{m}^{3} / \mathrm{s}$ no estado de São Paulo e em algumas Unidades de Gerenciamento de Recursos Hídricos entre 2004 e 2007 e projeção para 2015 e 2020

\begin{tabular}{lcccccc}
\hline \multicolumn{1}{c}{ UGRHI } & $\mathbf{2 0 0 4}$ & $\mathbf{2 0 0 5}$ & $\mathbf{2 0 0 6}$ & $\mathbf{2 0 0 7}$ & $\mathbf{2 0 1 5}$ & $\mathbf{2 0 2 0}$ \\
\hline Alto Tietê & 68,50 & 69,50 & 70,30 & 71,20 & 76,60 & 79,00 \\
\hline Tietê/Sorocaba & 5,27 & 5,35 & 5,41 & 5,46 & 6,48 & 7,06 \\
\hline Mogi-Guaçu & 3,79 & 3,81 & 3,83 & 3,86 & 4,48 & 4,80 \\
\hline Est. São Paulo & 135,02 & 135,81 & 136,45 & 137,33 & 152,86 & 160,73 \\
\hline
\end{tabular}

Fonte: DAEE, 2006.

Especialmente na região metropolitana da cidade de São Paulo a disponibilidade hídrica pode ser considerada crítica. Na região da bacia do Alto Tietê essa disponibilidade é menor que $1.500 \mathrm{~m}^{3} / \mathrm{hab} / \mathrm{ano}$ (DAEE, 2006). Isto está demonstrado na figura 1.1. 


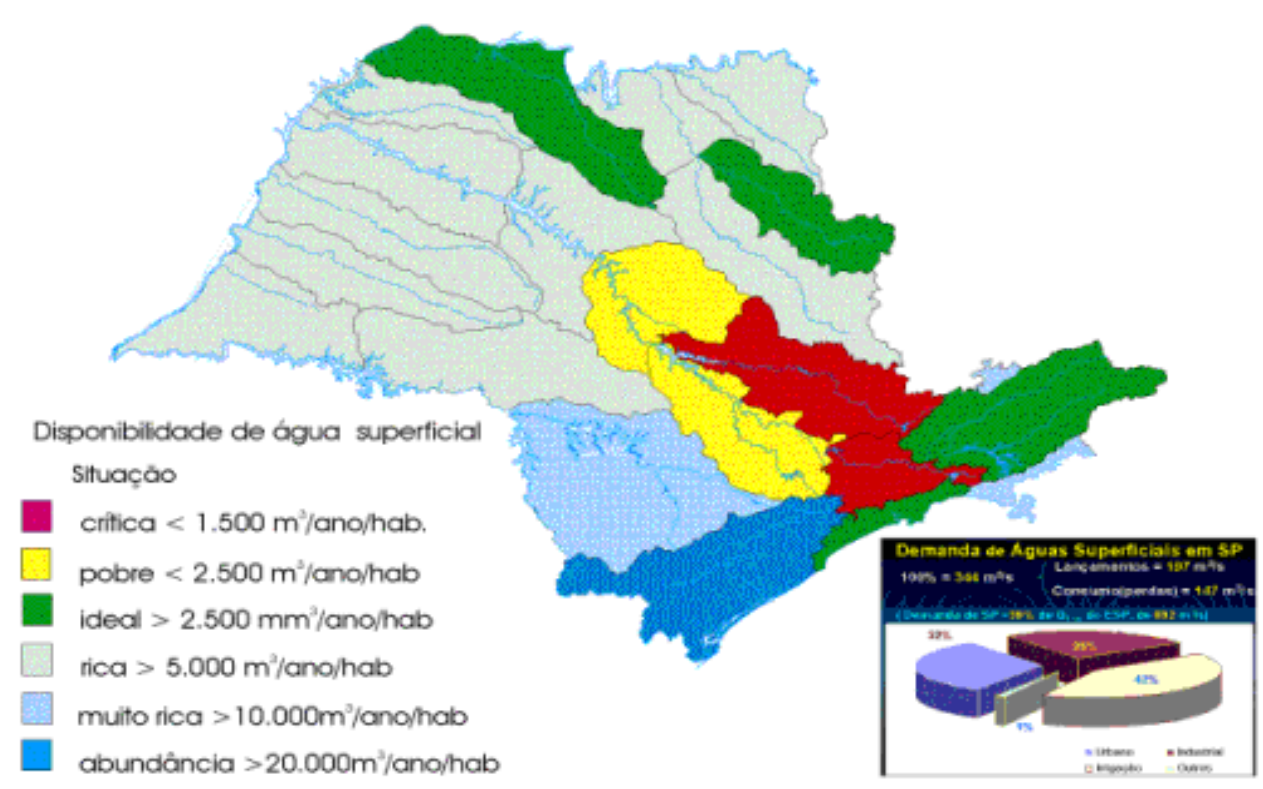

Figura 1.1 - Disponibilidade hídrica no estado de São Paulo (DAEE, 2006)

A bacia hidrográfica do Alto Tietê, possui uma relação entre a demanda e disponibilidade hídrica maior que $40 \%$, sendo assim considerada muito crítica (ANA, 2005). Assim sendo, considerando que a empresa em estudo encontra-se instalada na cidade de Cajamar, justamente na bacia do Alto Tietê, ela sofre também os efeitos dessa situação de disponibilidade crítica, tendo como preocupação a busca de meios para garantir o abastecimento do recurso água ao seu negócio de forma perene.

Para as empresas que têm a preocupação com o desenvolvimento de processos industriais previlegiando a conservação e evitam o desperdício de água, além do benefício econômico, têm um retorno importante ao garantir uma boa imagem, mostrando essas empresas como empreendimentos ou negócios ambientalmente responsáveis.

A utilização do recurso água na indústria de cosméticos envolve diferentes aspectos. Como e onde ela é utilizada determinam as características e a qualidade necessárias para essa água, bem como os tratamentos para se atingir os parâmetros de qualidade desejados. 
Dentro de um programa de conservação de água, as possibilidades de reúso direto nas operações de produção na indústria de cosméticos são limitadas pelo risco de contaminação do produto final por algum agente químico ou biológico que esteja presente nessa água. Assim, toda água que seja reaproveitada nos processos de fabricação deve no mínimo ter a condição de potabilidade garantida para que possa ser utilizada. Portanto, outras alternativas devem ser estudadas visando a diminuição do consumo e o uso racional da água.

\subsection{Justificativa deste trabalho}

A indústria de cosméticos, fortemente dependente do recurso água, assim como outros segmentos da economia, também passou a se preocupar com a sua conservação e utilização racional.

Apesar da importância do recurso água para o segmento industrial de fabricação de cosméticos verifica-se que este é um tema muito pouco explorado. Não existem muitas publicações ou artigos técnicos que tratem da utilização, conservação e reúso da água nos processos produtivos.

Uma vez que os produtos cosméticos têm evidente contato direto com seus consumidores, existe grande preocupação com os aspectos de qualidade da água empregada e com o atendimento aos requisitos de normas e leis de vigilância sanitária e saúde pública.

Assim este trabalho teve como motivação a possibilidade de contribuir com informações técnicas sobre o uso e conservação do recurso água e a identificação de oportunidades de economias neste segmento industrial. 


\section{OBJETIVOS}

Levando-se em conta a importância do recurso água para o segmento industrial e as crescentes dificuldades de sua obtenção devido a sua escassez e ao comprometimento das fontes disponíveis, este trabalho teve como objetivo principal estudar como o recurso é utilizado e pode ter seu consumo reduzido nos processos e atividades típicos de indústria do segmento de produção de cosméticos.

\subsection{Objetivos específicos}

- avaliar e identificar os processos em que o consumo de água é mais significativo;

- identificar oportunidades de economia nesses processos, considerando os critérios de racionalização do uso de água;

- avaliar a qualidade dos efluentes tratados e sua aplicação em programas de reúso menos exigentes, em termos de qualidade do efluente tratado;

- avaliar a possibilidade de reúso dos efluentes tratados em alguns processos com menores exigências, em substituição à água potável;

- descrever as práticas que resultaram na redução do consumo de água. 


\section{REVISÃO BIBLIOGRÁFICA}

\section{1 Água - recurso escasso}

A preocupação com a escassez do recurso água à primeira vista parece fazer sentido para regiões áridas ou semi-áridas, onde a água é um fator limitante para o desenvolvimento urbano, industrial e agrícola. É o caso do Nordeste brasileiro onde se procura continuamente novas fontes de recursos para complementar a pequena disponibilidade hídrica existente.

Entretanto, regiões altamente urbanizadas, como a metropolitana de São Paulo, cuja Bacia do Alto Tietê deve suprir a necessidade de uma população de cerca de 16 milhões de habitantes, além do maior parque industrial do país, apresenta relativa escassez, pois, pelas suas características de manancial de cabeceira, não consegue manter vazões suficientes para atender a demanda. Isto leva à busca por recursos hídricos de bacias vizinhas, com aumento de custo para captação e transporte, bem como cria problemas de ordem legal e político.

Como exemplo, em 2006 a transferência de água entre as UGRHI Piracicaba/Jundiaí/Capivari para a UGRHI Alto Tietê era de $31 \mathrm{~m}^{3} / \mathrm{s}$, através do Sistema Cantareira, para o abastecimento público da Região Metropolitana de São Paulo (Departamento de Águas e Energia Elétrica do estado de São Paulo, 2006).

Essa prática de transferência entre bacias encontra cada vez mais resistência uma vez que as populações e a própria sociedade estão cada vez mais conscientes do dever e da necessidade de proteção para o futuro de seus próprios mananciais que servem de fontes complementares às regiões de escassez.

Com isso torna-se válido o conceito estabelecido pelo Conselho Econômico e Social das Nações Unidas na política de gestão para áreas carentes de recursos hídricos que declara que "a não ser que exista grande disponibilidade, nenhuma água de boa qualidade deve ser utilizada para usos que toleram águas de qualidade inferior" (UNITED NATIONS, 1958). 
Assim, águas de qualidade inferior tais como esgotos domésticos, águas de drenagem agrícola, etc., devem ser consideradas como fontes alternativas para usos em aplicações em que não se tenha restrições. Mesmo as águas provenientes de efluentes industriais, considerando-se as suas características poluentes e as tecnologias apropriadas para seu tratamento e distribuição, devem ser consideradas como possíveis fontes alternativas de abastecimento para fins não potáveis, evitando-se a utilização de água com qualidade superior aos padrões necessários a um determinado fim. Infelizmente, nas indústrias essa prática pode ser encontrada em atividades ligadas ao processo de fabricação e mesmo em situações simples, como no uso de água potável em sanitários, levando ao desperdício desse recurso.

O mundo atualmente vive a "era da recuperação, reciclagem e reúso" (ASANO et al., 1998). A própria sobrevivência humana depende de sua capacidade de desenvolver meios de reaproveitamento dos recursos escassos, da garantia de sua proteção, da recuperação e reúso, especialmente do recurso água.

\subsection{O gerenciamento dos recursos hídricos}

A qualidade e a quantidade de água disponível podem sofrer alterações em decorrência de causas naturais e também antrópicas. O desenvolvimento econômico e a complexidade da organização das sociedades humanas produziram inúmeras alterações no ciclo hidrológico e na qualidade da água (TUNDISI, 2006).

Em relação à alteração da qualidade, seus principais causadores são (TOZE, 2006):

- os lançamentos de esgotos sanitários que contribuem com matéria orgânica, contaminantes biológicos, nutrientes e com substâncias de síntese química (hormônios e fármacos) presentes em medicamentos usados pela população,

- os resíduos decorrentes das atividades agrícolas (fertilizantes, pesticidas) levados pelos processos de irrigação e pelas chuvas e 
- os lançamentos de efluentes industriais, que contribuem com a contaminação por agentes químicos diversos.

No Brasil, pode-se dizer que a água somente passou a ter sua importância evidenciada a partir da década de 1980. Esse desinteresse devia-se à aparente abundância do recurso, ao baixíssimo custo associado a sua obtenção e tratamento, devido às boas qualidades das águas, geralmente águas de superfície. Assim não existia a preocupação com o controle de seu consumo ou mesmo com as condições em que água era devolvida ao meio ambiente, uma vez empregada no transporte e disposição dos efluentes e de sua carga poluidora, levando à contaminação de mananciais.

A mudança de conceito em relação à utilização dos recursos hídricos veio com o próprio aumento da industrialização, com o crescimento populacional e particularmente com a verticalização dos núcleos urbanos, que teve como conseqüência o comprometimento das fontes de abastecimento. Assim, esse recurso passou a ser buscado a distâncias maiores e a tornar-se mais escasso, ou até mesmo a ser mais oneroso o seu tratamento para que pudesse ser utilizado.

Ainda assim, além da contribuição humana com suas atividades para o comprometimento das fontes hídricas, tem-se a questão da perda desse recurso uma vez captado e tratado. Na cidade de São Paulo em 2007 perdeu-se 30,8 \% da água, em volume total, que foi retirada dos mananciais (ISA, 2007), antes que esta chegasse aos consumidores. A média nas capitais brasileiras em 2005 estava em $39,0 \%$ (ANA, 2005).

A valorização da importância do recurso fez com que o poder público desenvolvesse mecanismos para outorga e cobrança pela sua utilização.

A cobrança pelo uso da água é um dos instrumentos previstos na Lei das Águas (Lei $n^{\circ}$ 9.433/97) que instituiu:

- a gestão por bacias hidrográficas e implantação dos comitês de bacia;

- cobrança pelos usos da água em alguns estudos e bacia hidrográficas;

- destinação de recursos para a gestão de bacias hidrográficas; 
- implantação da Política Nacional de Recursos Hídricos e do Sistema Nacional de Gerenciamento de Recursos Hídricos.

Essa política está baseada em seis princípios:

1. a água é um bem público;

2. a água é um recurso finito e tem valor econômico;

3. o gerenciamento deve contemplar usos múltiplos;

4. em situação de escassez o abastecimento humano é prioritário;

5. a bacia hidrográfica representa a unidade territorial para fins gerenciais;

6. para o gerenciamento hídrico, devem participar: o governo, os usuários e os cidadãos.

Um bom exemplo das ações advindas da Lei $n^{\circ}$ 9.433/97 e que se iniciou com a bacia do Rio Paraíba do Sul, foi a cobrança pela água retirada desta bacia a partir de março de 2003. O objetivo deste instrumento foi estimular o uso racional da água e gerar recursos financeiros para investimentos na recuperação e preservação dos mananciais da região, valorizando o recurso que é de toda a sociedade (TUNDISI, 2006).

Outro bom exemplo da busca de soluções pelas empresas para os problemas de escassez e da necessidade de conservação da água é o projeto Aquapolo Ambiental, cujo protocolo de intenções foi assinado em janeiro de 2008, em que, liderado pela Petroquímica União (PQU), um consórcio de dez empresas do Pólo Petroquímico de Capuava - SP, utilizará água de reúso a partir do esgoto tratado na Estação de Tratamento de Esgotos do $A B C$ (ETE-ABC) para produção de água industrial. $\mathrm{O}$ volume previsto de $600 \mathrm{~L} / \mathrm{s}$ poderá chegar a $1.000 \mathrm{~L} / \mathrm{s}$, o que será equivalente ao consumo atual da cidade de Santos (SABESP, 2008) 


\subsection{A indústria de cosméticos e o uso da água}

O uso de cosméticos remonta há pelo menos 30.000 anos uma vez que os homens da pré-história, além de fazer gravações em rochas e cavernas, também pintavam o corpo e se tatuavam com tintas e corantes extraídos da Natureza que eram misturados à água ou óleos. A palavra perfume, que no latim quer dizer "através da fumaça", teve origem na queima de incenso em rituais religiosos. (SCHULLER; ROMANOWISKI, 2001).

Dentre todas as matérias primas, a água é a mais amplamente utilizada na formulação e fabricação de cosméticos. Além de usada como solvente de componentes (corantes, aditivos, etc.) a água constitui parte significativa da maioria dos cosméticos.

A fabricação de colônias emprega de 15 a 40 \% de água em sua composição. Cremes, de 45 a 75 \%. Loções, de 75 a 85 \%. Géis de limpeza, de 40 a 90 \%. Xampús, de 35 a 70 \% (WILKINSON; MOORE, 1990).

Além da incorporação no produto final, uma grande quantidade de água de qualidade superior (água potável e também água purificada) é utilizada em operações de limpeza e sanitização de equipamentos e utensílios, para garantir a qualidade do produto final. Dados da empresa em estudo mostram que do total de água consumida no setor industrial, cerca de $26 \%$ são efetivamente incorporados ao produto (NATURA, 2007).

A presença na água de impurezas como cálcio, magnésio, ferro e alumínio originam a lenta formação de resíduos invisíveis, freqüentemente agravada pela coprecipitação dos componentes menos solúveis da composição dos perfumes. Se houver a presença de compostos orgânicos fenólicos, tais como antioxidantes e estabilizadores de ultravioleta, podem-se ter alterações de cor devido à reação destes com traços de metais, formando compostos corantes (WILKINSON; MOORE, 1990). 
No caso de emulsões, a presença de grandes concentrações de íons inorgânicos, tais como magnésio e zinco, pode conduzir à separação de fases, por interferir no equilíbrio de cargas estáticas responsáveis pelo funcionamento adequado de certos tensoativos da fórmula. A presença desses íons em cremes, loções e xampús pode levar à alteração de viscosidade.

Outro aspecto importante é a presença na água de contaminantes microbiológicos. Se houver a proliferação de microorganismos no cosmético, o resultado será a inutilização do produto devido ao desenvolvimento de odores desagradáveis, colônias visíveis de bactérias, mofo ou fungos e, no caso de emulsões, a separação de fases. A tudo isso se soma o mais grave que é o risco potencial à saúde do consumidor (WILKINSON; MOORE, 1990).

A Portaria $n^{\circ} 518 / 2004$ do Ministério da Saúde estabelece os procedimentos e responsabilidades relativas ao controle e vigilância da qualidade da água para consumo humano e seu padrão de potabilidade, porém, para o uso na indústria de cosméticos, água com características específicas deve ser empregada em alguns processos.

Apesar da importância da água para a indústria de cosméticos não existe uma legislação nacional e mesmo internacional que especifique os padrões de qualidade necessários para o uso da água nesse segmento industrial. Assim são utilizados os padrões de qualidade definidos nas normas regulatórias para a indústria de alimentos ou farmacêutica.

A tabela 3.1 mostra uma lista das principais normas regulatórias às quais estão sujeitas os produtos cosméticos, de higiene pessoal e perfumes no Brasil.

Tabela 3.1 - Principais normas regulatórias para os produtos cosméticos

\begin{tabular}{cl}
\hline Norma regulatória & \multicolumn{1}{c}{ Ação } \\
\hline Lei $n^{\circ}$ 6.360, de 23/9/1976 & $\begin{array}{l}\text { Dispõe sobre a vigilância sanitária a que ficam } \\
\text { sujeitos os medicamentos, drogas insumos } \\
\text { farmacêuticos, cosméticos, saneantes e outros. }\end{array}$ \\
\hline
\end{tabular}

Decreto $n^{\circ}$ 79.094, de 5/1/1977 Regulamenta a Lei $n^{\circ}$ 6.360/76. 
Tabela 3.1 - Principais normas regulatórias para os produtos cosméticos (continuação)

\begin{tabular}{|c|c|}
\hline Norma regulatória & Ação \\
\hline Lei $n^{\circ} 6.480$, de $1 / 12 / 1977$ & Altera a Lei $n^{\circ} 6.360 / 77$. \\
\hline Decreto $n^{\circ} 83.239$, de 6/3/1979 & $\begin{array}{l}\text { Altera o Decreto } n^{\circ} 79.094 / 77 \text { que regulamenta a Lei } \\
n / 6.360 / 76 \text {. }\end{array}$ \\
\hline $\begin{array}{l}\text { Portaria SNVS } n^{\circ} 348 \text {, de } \\
18 / 8 / 1997\end{array}$ & $\begin{array}{l}\text { Determina o cumprimento das diretrizes } \\
\text { estabelecidas no Regulamento Técnico - Boas } \\
\text { Práticas de Fabricação e Controle para Produtos de } \\
\text { Higiene Pessoal, Cosméticos e Perfumes e institui o } \\
\text { Roteiro de Inspeção. }\end{array}$ \\
\hline Lei n 9.782, de 26/1/1999 & $\begin{array}{l}\text { Define o Sistema Nacional de Vigilância Sanitária e } \\
\text { cria a ANVISA - Agência Nacional de Vigilância } \\
\text { Sanitária }\end{array}$ \\
\hline $\begin{array}{l}\text { Resolução ANVS } n^{\circ} 335 \text {, de } \\
22 / 7 / 1999\end{array}$ & $\begin{array}{l}\text { Estabelece a reorganização do sistema de controle } \\
\text { sanitário de produtos de higiene pessoal, cosméticos, } \\
\text { perfumes, notificação de produtos de grau de risco } 1 \\
\text { e } 2 \text { e verificação do cumprimento das Boas Práticas } \\
\text { de Fabricação e Controle. }\end{array}$ \\
\hline $\begin{array}{l}\text { Resolução ANVS } n^{\circ} 481 \text {, de } \\
23 / 9 / 1999\end{array}$ & $\begin{array}{l}\text { Estabelece os Parâmetros de Controle Microbiológico } \\
\text { para produtos de higiene pessoal, cosméticos e } \\
\text { perfumes. }\end{array}$ \\
\hline $\begin{array}{l}\text { Resolução ANVS } n^{\circ} 79 \text {, de } \\
28 / 8 / 2000\end{array}$ & $\begin{array}{l}\text { Estabelece a definição e classificação dos produtos } \\
\text { de higiene pessoal, cosméticos e perfumes entre } \\
\text { outros procedimentos. }\end{array}$ \\
\hline Decreto $n^{\circ} 3.961$, de 10/10/2001 & $\begin{array}{l}\text { Altera o Decreto } n^{\circ} 79.094 / 77 \text { que regulamenta a Lei } \\
n^{\circ} 6.390 / 76 \text {. }\end{array}$ \\
\hline
\end{tabular}

Fonte: modificado de SCHUELLER e ROMANOWISKI, 2001.

A Portaria $n^{\circ} 348$ de 18 de agosto de 1997 determina as diretrizes que devem ser seguidas para as "Boas Práticas de Fabricação para Produtos de Higiene Pessoal, Cosméticos e Perfumes". Entretanto não especifica padrões de qualidade da água a ser usada nos diferentes processos ou mesmo para incorporação ao produto. Estabelece apenas procedimentos de caráter geral conforme abaixo:

"Água: Por sua importância dentro do conjunto de matérias-primas, deve ter atenção particular. 
Os equipamentos de produção de água, assim como outros sistemas que possam existir, devem garantir uma qualidade de água que assegure, por sua vez, a conformidade do produto acabado.

Deve ser passível de proceder-se a sistemas de desinfecção, conforme procedimentos bem definidos.

As tubulações devem ser constituídas de forma a evitar corrosão, riscos de contaminação e estancamento.

Os materiais devem ser escolhidos de forma que a qualidade da água não seja afetada.

Devem ser identificadas as tubulações de água quente, fria, desmineralizada e a vapor. A qualidade química e microbiológica deve ser monitorada regularmente de acordo com procedimentos escritos e qualquer anomalia deve ser seguida de uma ação corretiva."

A Portaria n 348/1997 também apresenta um questionário (lista de verificação) que deve servir de guia para as inspeções nas indústrias, em que cada item é classificado como $\mathrm{R}$ - recomendável, N - necessário, I - imprescindível ou INF informativo.

Na seção 5. Sistemas e Instalações de Água, têm-se as seguintes perguntas:

\begin{tabular}{|l|l||}
\hline INF & A empresa utiliza água potável? \\
\hline INF & A empresa utiliza água purificada? \\
\hline \hline & Água Potável \\
\hline INF & Qual a procedência da água utilizada na empresa? \\
\hline $\mathrm{R}$ & A empresa possui caixa d'água? \\
\hline $\mathrm{N}$ & É feito algum tratamento antes da água ser armazenada? \\
\hline $\mathrm{N}$ & É feita limpeza da caixa d'água? \\
\hline $\mathrm{R}$ & Existem procedimentos escritos para a limpeza da caixa d'água? \\
\hline $\mathrm{N}$ & São feitos testes físico-químicos? \\
\hline $\mathrm{N}$ & São feitos testes bacteriológicos? \\
\hline $\mathrm{N}$ & São colhidas amostras de água em diversos pontos da fábrica, para efetuar a contagem \\
\hline $\mathrm{N}$ & As tubulações utilizadas para transporte de água potável estão em bom estado de \\
\hline $\mathrm{R}$ & A provisão de água faz-se sob pressão positiva contínua, em um sistema livre de defeitos? \\
\hline \hline & Água Purificada \\
\hline INF & A água potável é usada como fonte de alimentação para sistemas de produção de água \\
\hline \hline & Deionização \\
\hline INF & A indústria possui equipamento deionizador, para produção de água purificada? \\
\hline
\end{tabular}




\begin{tabular}{|c|c|}
\hline INF & A água que abastece o deionizador é tratada? \\
\hline $\mathrm{R}$ & Existe pessoal capacitado para operar o sistema? \\
\hline$R$ & Existe manual de operação para o sistema? \\
\hline $\mathrm{N}$ & As resinas são regeneradas com freqüência? \\
\hline INF & Se a água que abastece o deionizador é clorada, existe um sistema para a retirada do cloro \\
\hline INF & Existe depósito para a água deionizada? \\
\hline $\mathrm{N}$ & São feitos testes físico químicos? \\
\hline $\mathrm{N}$ & São feitos testes bacteriológicos? \\
\hline $\mathrm{N}$ & O transporte ou circulação da água deionizada é feito por tubulação ou outro meio \\
\hline $\mathrm{R}$ & É liberada pelo Controle de Qualidade antes de ser utilizada? \\
\hline $\mathrm{N}$ & É feita sanitização do sistema? \\
\hline $\mathrm{N}$ & Existem procedimentos escritos para a sanitização do sistema? \\
\hline INF & É feita manutenção preventiva nos equipamentos do sistema? \\
\hline R & Existe algum tipo de filtro no sistema? \\
\hline $\mathrm{N}$ & É feita sanitização dos cartuchos? \\
\hline $\mathrm{N}$ & Existem procedimentos escritos para sanitização dos cartuchos? \\
\hline \multirow[t]{2}{*}{$\mathrm{N}$} & O sistema de purificação é validado? \\
\hline & Osmose Reversa (quando for o caso) \\
\hline INF & A indústria possui equipamento de água por osmose reversa para produção de água \\
\hline INF & A água que abastece o sistema é tratada? \\
\hline $\mathrm{N}$ & Existe pessoa capacitada para operar o sistema? \\
\hline $\mathrm{R}$ & Existe manual de operação do sistema? \\
\hline INF & Existe depósito para esta água? \\
\hline N & São feitos testes físico-químicos? \\
\hline $\mathrm{N}$ & São feitos testes bacteriológicos? \\
\hline N & O transporte ou circulação desta água é feito por tubulação ou outro meio adequado? \\
\hline $\mathrm{R}$ & É liberada pelo controle de qualidade antes de ser utilizada? \\
\hline $\mathrm{N}$ & É feita sanitização do sistema? \\
\hline $\mathrm{N}$ & Existem procedimentos escritos para a sanitização do sistema? \\
\hline INF & É feita manutenção preventiva nos equipamentos do sistema? \\
\hline$R$ & Existe algum tipo de filtro no sistema? \\
\hline $\mathrm{N}$ & É feita a sanitização dos cartuchos? \\
\hline N & Existe procedimento escrito para a sanitização dos cartuchos? \\
\hline $\mathrm{N}$ & O sistema de purificação é validado? \\
\hline
\end{tabular}

Outra legislação que pode ser aplicada é a Resolução $n^{\circ} 210$, de 04 de agosto de 2003 da ANVISA que, da mesma forma que a Portaria $n^{\circ} 348 / 1997$, determina as diretrizes que devem ser seguidas para as "Boas Práticas de Fabricação para Medicamentos".

Para a definição de padrões de qualidade da água pode ser empregada a Farmacopéia Brasileira e, considerando-se as indústrias que têm a possibilidade de exportação de produtos a outros países, são também empregadas as farmacopéias Européia ou Americana. 
Em razão da grande similaridade da indústria brasileira com a indústria americana segue-se preferencialmente a farmacopéia americana, USP -The United States Pharmacopoeia, (FONTANA JR., 2001), que atualmente está em sua $32^{a}$ edição.

$\mathrm{Na}$ farmacopéia americana define-se os seguintes tipos de água para uso em indústrias farmacêuticas (U.S. Pharmacopeia, 2007):

- Água Potável;

- Água Purificada;

- Água Purificada Esterilizada;

- Água para Injeção;

- Água para Injeção Esterilizada;

- Água Bacteriostática para Injeção;

- Água Estéril para Irrigação; e

- Água Estéril para Inalação.

Em geral, na indústria cosmética a água é empregada nos seguintes processos (WILKINSON; MOORE, 1990):

- como matéria prima que deve ser incorporada ao produto podendo variar de $20 \%$ a $80 \%$ da composição típica

- como diluente ou veículo na preparação de matérias primas como no caso de corantes e aditivos

- na lavagem e limpeza de tanques, equipamentos e utensílios utilizados nos processos de fabricação

- na lavagem e limpeza de pisos e ambientes de fabricação 
- no transporte de resíduos em geral, como efluente dos processos de fabricação

- como meio de resfriamento ou aquecimento (água gelada, água quente ou vapor)

- para limpeza de ruas e áreas externas bem como irrigação de jardins e lâminas d'água decorativas para efeito paisagístico

- para consumo e uso na higiene pessoal dos empregados da empresa

\subsection{Meios de obtenção e tratamento da água para fins industriais}

Como já mencionado o recurso água pode ter as mais diversas utilizações. Para a indústria, conforme o ramo de atividade, fatores como quantidade disponível, garantia de fornecimento, custo de obtenção e qualidade, são dos mais importantes.

Por melhor que seja a fonte de águas sempre haverá a presença de materiais de distintas características e procedências que exigem que, antes de sua utilização, a água seja tratada adequadamente visando o atendimento das especificações de cada uso particular nas indústrias. As principais características físicas das águas são a cor, a turbidez, os níveis de sólidos em suas diversas frações, a temperatura, o sabor e o odor. Já as principais características químicas são, por sua vez o $\mathrm{pH}$, a acidez, a alcalinidade e a dureza e a presença de diversas substâncias químicas, orgânicas e inorgânicas.

A necessidade de adequação das características físicas, químicas e biológicas da água aos padrões de qualidade estéticos, econômicos e de higiene faz com que uma seqüência de tratamentos seja empregada (REBOUÇAS et al., 2006). 


\section{Tratamento convencional visando obtenção de água potável}

Os tratamentos convencionais geralmente aplicados às águas brutas para obtenção de água potável compõem-se das etapas que estão resumidas na tabela 3.2:

Tabela 3.2 - Etapas de um tratamento convencional para água potável

\begin{tabular}{|c|c|}
\hline Etapa & Ação \\
\hline $\begin{array}{l}\text { a) Aeração ou pré- } \\
\text { cloração }\end{array}$ & 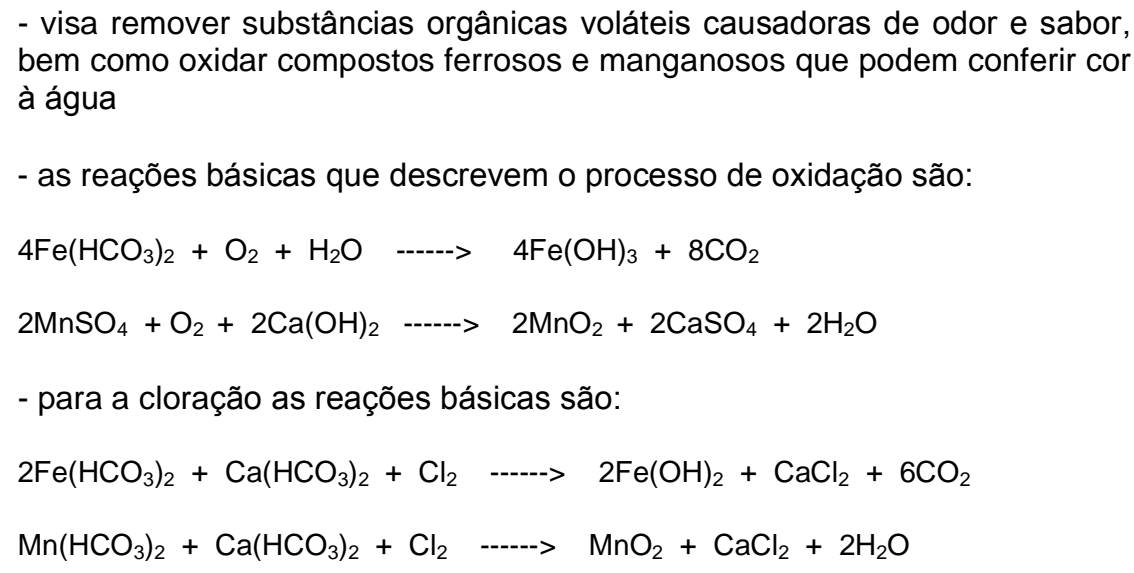 \\
\hline $\begin{array}{l}\text { b) Coagulação - } \\
\text { Floculação }\end{array}$ & $\begin{array}{l}\text { - visa promover a separação dos sólidos em suspensão, partículas finas em } \\
\text { estado coloidal suspensas no meio aquoso devido às cargas elétricas } \\
\text { superficiais; } \\
\text { - com a aplicação de coagulantes tais como sulfato de ferro e alumínio e } \\
\text { polieletrólitos adequados consegue-se a formação de flocos grandes e } \\
\text { pesados que são mais facilmente removidos por sedimentação. }\end{array}$ \\
\hline c) Decant & $\begin{array}{l}\text { - com o uso da aceleração da gravidade separa-se da água o material } \\
\text { floculado obtido na etapa de coagulação e floculação. } \\
\text { - com a aplicação de coagulantes tais como sulfato de ferro e alumínio e } \\
\text { polieletrólitos adequados consegue-se a formação de flocos grandes e } \\
\text { pesados que são mais facilmente removidos por sedimentação. }\end{array}$ \\
\hline d) Filtração & $\begin{array}{l}\text { - a água efluente do sistema de decantação passa por filtros que retém os } \\
\text { sólidos suspensos remanescentes. }\end{array}$ \\
\hline e) Desinfecção & $\begin{array}{l}\text { - consiste na dosagem de agentes desinfectantes, sendo os mais utilizados } \\
\text { os derivados clorados (mas também podendo ser o ozônio ou radiação } \\
\text { ultravioleta), visando a eliminação dos organismos patogênicos presentes } \\
\text { na água. }\end{array}$ \\
\hline $\begin{array}{l}\text { f) Controle de } \\
\text { corrosão }\end{array}$ & $\begin{array}{l}\text { - na indústria é importante que a água não possua características } \\
\text { corrosivas, processo favorecido pela presença de gás carbônico, ácidos } \\
\text { diluídos ou cloretos, assim pode ser necessário um ajuste químico com } \\
\text { adição de cal e ajuste de } \mathrm{pH} \text {. }\end{array}$ \\
\hline
\end{tabular}

Fonte: modificado de Rebouças et al (2006) 


\section{Tratamentos visando obtenção de água purificada}

Considerando-se que os processos de produção da indústria farmacêutica são muito semelhantes aos da indústria de cosméticos, utiliza-se Água Purificada como ingrediente na preparação de aditivos, limpeza de equipamentos críticos e na composição dos produtos (FONTANA JR., 2001). Essa água deve possuir os seguintes parâmetros, conforme a tabela 3.3:

Tabela 3.3 - Parâmetros de qualidade para utilização de água purificada

\begin{tabular}{ll}
\hline \multicolumn{1}{c}{ Parâmetro } & \multicolumn{1}{c}{ Critério de qualidade } \\
\hline $\mathrm{pH}$ & $5 \sim 7$ \\
\hline Condutividade & $0,6 \sim 4,7 \mu \mathrm{S} / \mathrm{cm}$ a $20^{\circ} \mathrm{C}$ \\
\hline Contagem bacteriológica & $<100 \mathrm{ufc} / 100 \mathrm{ml}$ \\
\hline COT & $<500 \mathrm{ppb}$ \\
\hline
\end{tabular}

Fonte: U.S. Pharmacopeia, 2007

Para a obtenção de água com esse padrão de qualidade os seguintes tratamentos são possíveis, partindo-se da água potável disponível:

- Sistema de troca iônica

- Sistemas de osmose reversa

- Sistemas de destilação

\section{Troca iônica por passagem em leito de resinas}

De todos esses métodos o que é mais utilizado é o de troca iônica devido ao seu menor custo de implantação e operação.

Nesse processo a água potável após passar por sistemas de filtração em leito de areia, para retirar sólidos em suspensão e também em leito de carvão ativado, para remoção do cloro livre, como medida de proteção das resinas. Em seguida a água passa por leitos de resina catiônica, onde ocorre a remoção de cátions $\mathrm{Ca}^{++}, \mathrm{K}^{++}$, 
$\mathrm{Na}^{+}, \mathrm{Mg}++$, substituídos por cátion hidrogênio $\left(\mathrm{H}^{+}\right)$. Depois a água passa por leitos de resina aniônica, onde ocorre a substituição dos ânions $\mathrm{SO}_{4}^{-2}, \mathrm{NO}_{3}{ }^{-}, \mathrm{Cl}^{-}, \mathrm{HCO}_{3}{ }^{-}$, $\mathrm{HSiO}_{3}^{-}$, por ânion hidroxíla $\left(\mathrm{OH}^{-}\right)$(CUNHA, 1991). A figura 3.1 exemplifica o processo:

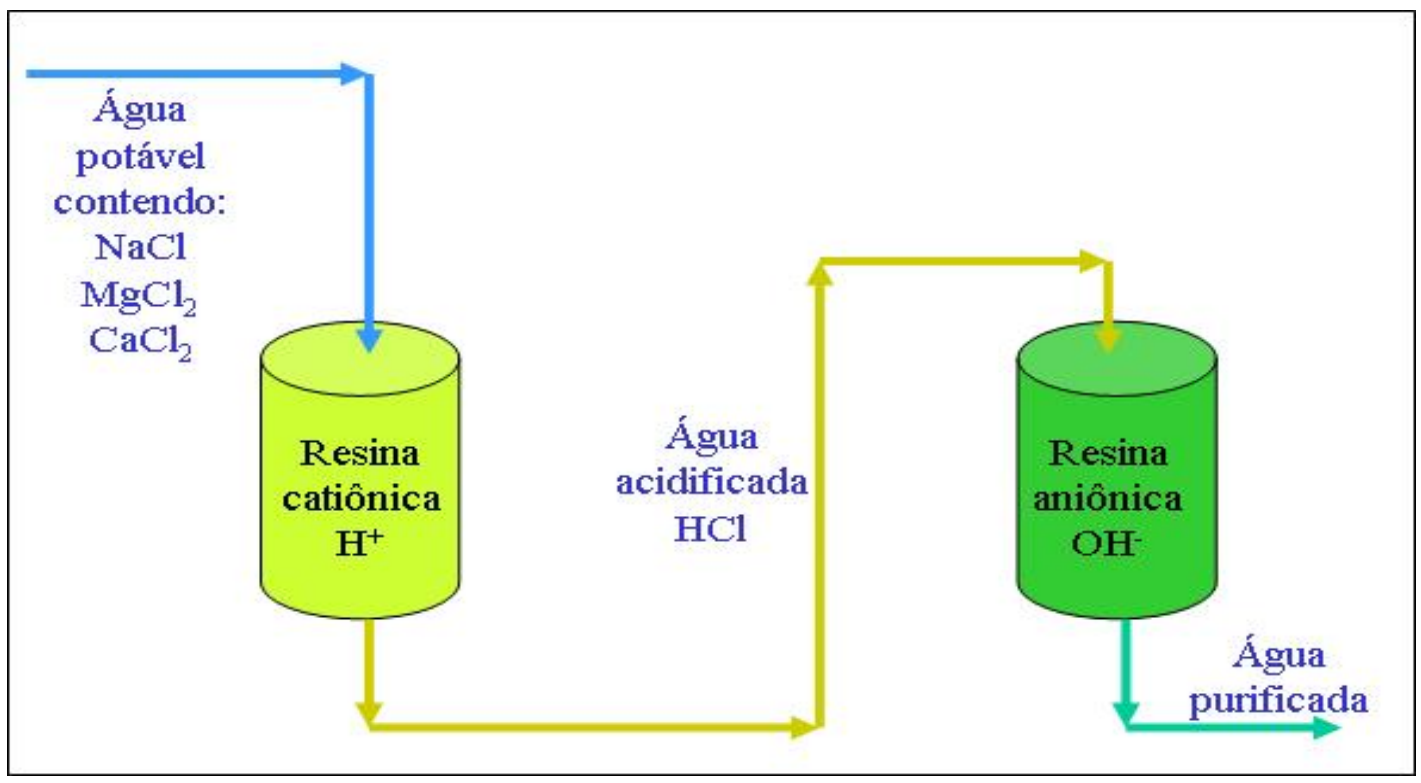

Figura 3.1 - Processo de desmineralização por resina de troca iônica (elaborado pelo autor)

A regeneração das resinas catiônicas deve ser realizada com ácido sulfúrico ou clorídrico (mais empregado) e a regeneração das resinas aniônicas com solução de hidróxido de sódio.

Emprega-se atualmente, com freqüência, uma combinação das resinas catiônicas e aniônicas em um mesmo leito, chamado então de sistema de leito misto. Esse arranjo é particularmente interessante para as águas brasileiras que, em geral, possuem baixa salinidade se comparadas às águas de outros países. Isso torna mais econômico o processo devido ao menor número de componentes e equipamentos. 


\section{Osmose reversa}

Outro processo de produção de água purificada utiliza a tecnologia de osmose reversa. Nesse processo a água potável após tratamento prévio passa sob pressão tangencialmente por um conjunto de elementos de membranas semipermeáveis, que permitem que a água permeie através da membrana deixando na corrente original os íons e outras impurezas indesejáveis. Essa tecnologia, embora já bastante consolidada, ainda é pouco empregada no Brasil devido aos custos elevados de implantação e complexidade do processo, com equipamentos e sistemas de controle que apresentam maior nível de automação e necessitam de pessoal operacional melhor preparado.

Um esquema básico do sistema é representado pela figura 3.2. O desempenho de um sistema de osmose reversa depende dos seguintes fatores (SCHNEIDER; TSUTIYA, 2001):

- Temperatura: a rejeição de sais diminui com o aumento de temperatura.

- Pressão: a rejeição aumenta com o aumento da pressão.

- $\mathrm{pH}$ : a rejeição é relativamente constante na faixa de $\mathrm{pH}$ de operação.

- Concentração de sais: a qualidade do permeado diminui com o aumento da concentração de sais na água de alimentação.

- Rendimento: a qualidade do permeado diminui com o aumento do rendimento da membrana. 


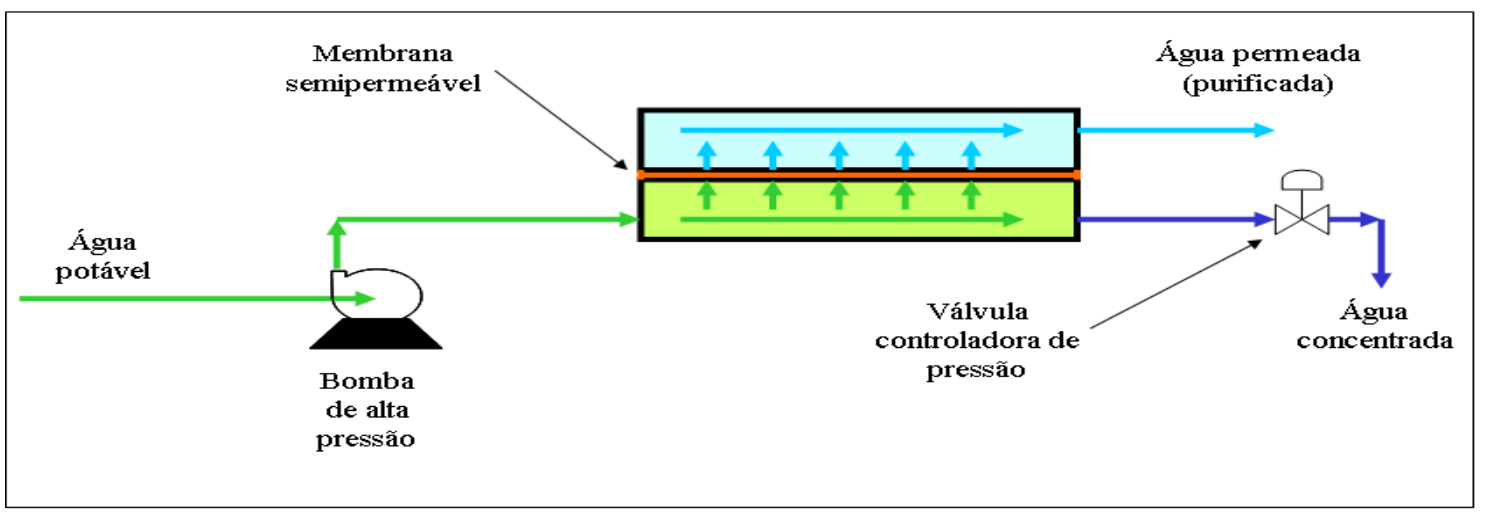

Figura 3.2 - Processo de purificação por osmose reversa (elaborado pelo autor)

O processo de osmose reversa permite diversas configurações, que envolvem a possibilidade de recirculação, o que aumenta a produção de água, e a utilização de duplo passe, melhorando a sua eficiência do ponto de vista de separação de sais, porém diminuindo a sua vazão de produção.

As membranas atualmente utilizadas podem ser acondicionadas em sistemas modulares que podem ser multiplicados conforme a necessidade.

A água potável que alimenta o sistema de osmose reversa deve ser pré-tratada para que esteja livre de impurezas e de cloro que podem danificar ou reduzir a vida útil das membranas. O sistema de pré-tratamento bem como o próprio conjunto de módulos de membranas necessitam de um bom controle de limpeza e também de sanitização periódica (SCHNEIDER; TSUTIYA, 2001).

\section{Destilação}

O terceiro processo para purificação de água, a destilação, é mais empregado na indústria farmacêutica para obtenção de água estéril em pequenas quantidades. Como meio de obtenção de grandes quantidades de água purificada a destilação apresenta custo elevado, em decorrência da energia envolvida. Além da energia consumida para o sistema de evaporação é necessário igualmente um sistema de refrigeração para condensar o vapor para fase líquida. Tudo isso faz com que seja um sistema não utilizado nas operações industriais da indústria cosmética (WILKINSON; MOORE, 1990). 


\subsection{Tratamento de efluentes}

Além do consumo e, portanto, da retirada dos mananciais de grandes volumes de água, necessários ao processo produtivo nas indústrias, outra questão essencial é como retornar essa água ao ambiente e em que condições.

Após a sua utilização, nos diferentes processos e também pela população de um empreendimento industrial, a água acumulará impurezas e contaminantes que levarão a alterações de suas características (VON SPERLING, 2005):

- físicas: gases ou sólidos (suspensos, coloidais ou dissolvidos);

- químicas: substâncias inorgânicas ou orgânicas;

- biológicas: seres vivos (animais, vegetais e microorganismos).

Assim essas águas residuárias devem ser tratadas adequadamente para que atendam aos padrões de qualidade que possibilitem seu lançamento nos corpos hídricos.

As legislações que definem tais padrões de qualidade são:

- quanto ao padrão de qualidade de corpos d'água: Resolução CONAMA 357/2005, do Ministério do Meio Ambiente e legislações estaduais como o Decreto Estadual n 8468/1997

- quanto ao padrão de lançamento de efluentes: Resolução CONAMA $357 / 2005$ e legislações estaduais como o Decreto Estadual $n^{\circ}$ $8468 / 1997$

- quanto ao padrão de lançamento de efluentes: Resolução CONAMA $397 / 2008$

O tratamento das águas residuárias envolvem diferentes níveis (METCALF, 2003): 
- Pré-tratamento (ou primário): retirada de sólidos grosseiros e remoção de sólidos sedimentáveis e parte da matéria orgânica.

- Tratamento secundário: predominam mecanismos biológicos para remoção da matéria orgânica e nutrientes;

- Tratamento terciário (ou complementar): objetiva a remoção de poluentes específicos ou de poluentes não suficientemente removidos no nível secundário.

Para a indústria de cosméticos, onde seus efluentes contém grandes quantidades de material inorgânico (corantes, componentes inorgânicos) e orgânico (essências, óleos e graxas), é comum um tratamento físico-químico para retirada desses compostos. Basicamente se tem a adição de coagulantes/floculantes e correção de pH, seguido de separação dos flocos por decantação e posterior filtração.

Após isso o efluente industrial se junta ao efluente sanitário e passam por um tratamento biológico. Os tratamentos mais utilizados são os sistemas anaeróbios ou aeróbios. O que define o tipo de tratamento é a disponibilidade de espaço, presença de comunidades vizinhas ao empreendimento, o padrão de lançamento de efluentes permitido e custos da implantação e operação do sistema de tratamento.

O interesse no reaproveitamento e reúso do efluente tratado para suprir as necessidades de água para alguns dos processos industriais na própria empresa faz surgir novas tecnologias como o uso conjugado de tratamento biológico com membranas de ultrafiltração ou microfiltração, e até mesmo a possibilidade do uso de osmose reversa para melhorar os parâmetros de qualidade desse efluente tratado para que possa ser utilizado em aplicações mais nobres. Um estudo piloto visando a reciclagem e reutilização de efluentes tratados de lavanderias foi conduzido por Hoinks e Panten (2008), mostrando a possibilidade da aplicação de tecnologias conjugadas que, para esse segmento industrial, possibilita a reciclagem de 70 a $80 \%$. 


\subsection{Conservação e uso racional da água nas indústrias}

No Brasil, somente em 1992, na "Conferência Interparlamentar sobre Desenvolvimento e Meio Ambiente", é que se teve uma demonstração de vontade política voltada à institucionalização do reúso de água. No item "Conservação e Gestão de Recursos para o Desenvolvimento" recomendou-se o incentivo da reciclagem e reúso de água sempre que possível, assim como a promoção do tratamento e da disposição de esgotos de maneira a não poluir o meio ambiente. Isso é uma das ações previstas na Agenda 21 brasileira (CDPS, 2004).

Define-se reúso como o aproveitamento de águas previamente utilizadas, uma ou mais vezes, em alguma atividade humana, para suprir as necessidades de outros usos benéficos, inclusive o original, podendo ser direto ou indireto, bem como decorrer de ações planejadas ou não planejadas (ASANO et al., 1998).

Define-se reciclagem de água como o reúso interno da água, antes de sua descarga em um sistema geral de tratamento ou outro local de disposição, para servir como fonte suplementar de abastecimento do uso original. É um caso particular do uso direto (ASANO et al., 1998).

Pode-se classificar o reúso em duas categorias: reúso potável ou reúso não potável. Ou ainda através da classificação que leva em conta se o uso é direto ou indireto dessa água.

Assim, a água, uma vez poluída pelas atividades humanas, pode ser recuperada e reusada para fins benéficos diversos. Porém a possibilidade de reúso depende de muitos fatores relacionados às suas características de qualidade físicas, químicas e biológicas.

A qualidade da água disponível e a finalidade de seu uso é que definirão o tipo de sistema de tratamento que deve ser empregado, os investimentos necessários, os custos de operação e manutenção desses sistemas e o nível de segurança que deve ser garantido. 
Além desses fatores técnico-econômicos, barreiras de caráter social e cultural devem ser vencidas, como a repulsa em geral que as pessoas podem apresentar à utilização de água que sabidamente foi produzida a partir de esgotos. Para isso a qualidade estética da água, como a presença de cor, aspecto e odor, deve ser adequadamente tratada, bem como campanhas de orientação e informação da população sobre os benefícios de um programa de reúso e da garantia de segurança aos usuários quanto a presença de agentes de risco à saúde. Também deve ser obtido o apoio político e institucional como, por exemplo, o apoio na aprovação de leis que facilitem e permitam o reúso. As questões relacionadas ao risco à saúde pública e a aceitação pela população estão entre as principais restrições ao reúso de água (HUERTAS et al., 2006).

As possibilidades de reúso podem ser descritas através do diagrama da figura 3.3:

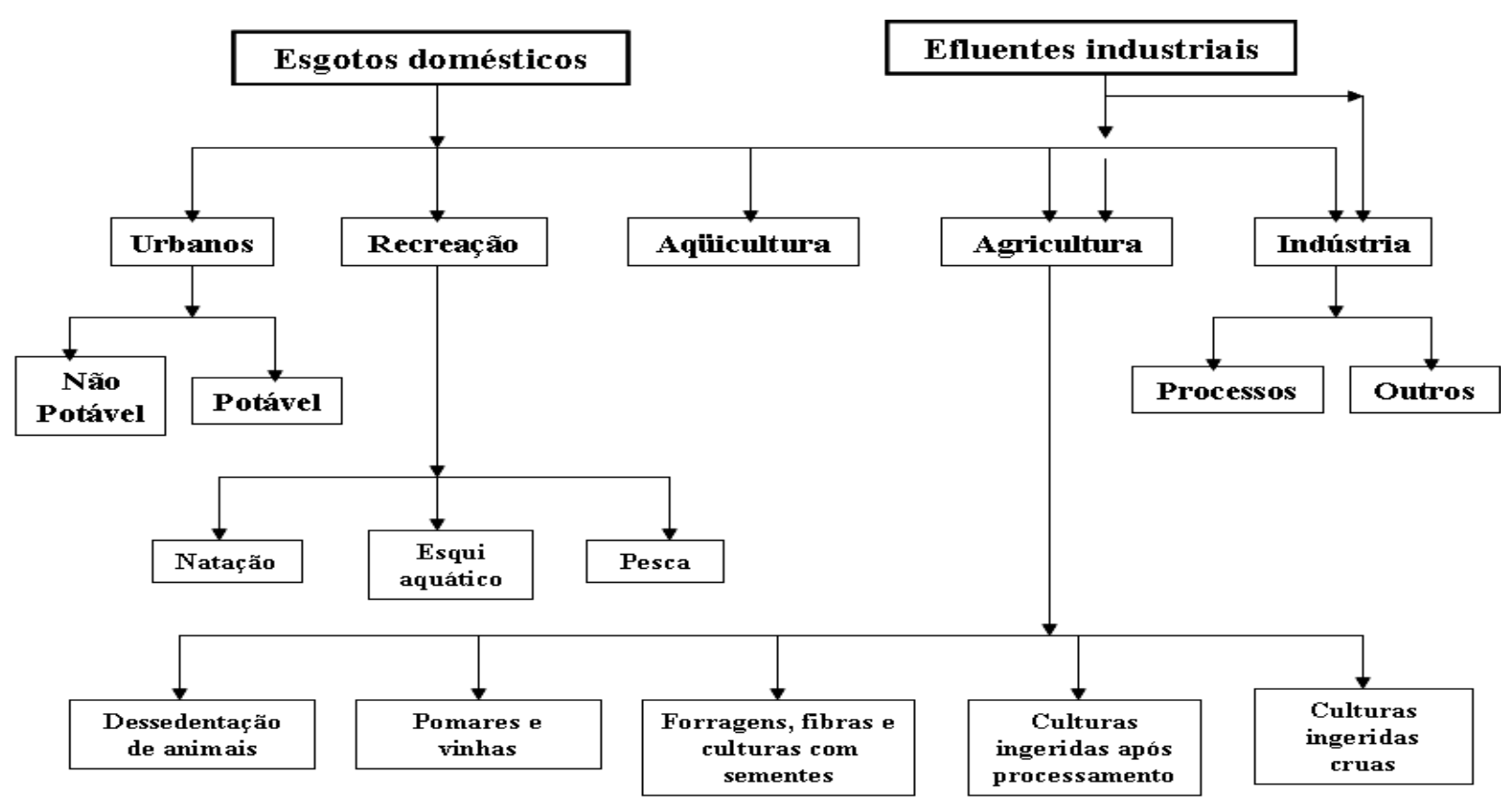

Figura 3.3 - Tipos de reúso (HESPANHOL, 1997)

No caso de reúso na indústria pode-se ter como fontes esgotos sanitários e efluentes industriais. Tem-se aqui uma forma de reúso direto e planejado em que os efluentes, após devidamente tratados, são encaminhados diretamente de seu ponto 
de descarga até o local do reúso, podendo sofrer no percurso tratamentos adicionais e armazenamentos necessários, mas sem descarga ao meio ambiente.

A princípio, desde que haja um planejamento adequado, com o levantamento das necessidades de água em cada etapa dos processos industriais, suas características em relação à qualidade requerida, bem como o conhecimento das condições da água disponível, pode-se reutilizar a água até mesmo no processo que a gerou (MIERZWA, 2002). Assim o aproveitamento como reúso pode ocorrer de diversas formas:

- uso direto do efluente da ETE;

- uso do efluente tratado da ETE, após tratamentos adicionais para adequação à necessidade requerida pelos processos industriais

- uso em cascata dos efluentes, de modo que o que sai de determinado processo seja reaproveitado em outro, sem que tenha sido enviado à ETE para tratamento.

A última opção é a que seria mais interessante do ponto de vista de conservação, pois não seria necessária a utilização de "água nova" nos processos industriais, resultando na diminuição do volume de efluente final a ser tratado na ETE, diminuição do custo de transporte e movimentação de água e efluentes e, finalmente, diminuição da captação de água pela empresa.

Em geral as opções para reúso são basicamente as seguintes (MANCUSO; SANTOS, 2003):

a) uso em torres de resfriamento

b) uso em caldeiras e geradores de vapor

c) uso na construção civil (compactação de solo e cura de concreto)

d) uso na lavagem de pisos e ruas

e) uso na irrigação de áreas verdes para jardinagem/paisagismo 
f) uso na lavagem de peças e equipamentos, especialmente na indústria mecânica e metalúrgica

g) uso em processos industriais

Os cuidados com o reúso na indústria devem considerar as características da água e da aplicação pretendida. Assim pode-se considerar que:

- para os usos referentes aos itens "c" e "d", têm-se a possibilidade de reúso sem grandes restrições quanto à qualidade da água;

- para o item "e" pode ser necessária a aprovação do órgão de controle ambiental devido a possibilidade de contaminação do solo pela água empregada, mesmo considerando que a aplicação em jardinagem/paisagismo não tem os mesmos riscos que na aplicação na agricultura;

- para os usos referentes ao item "a" tem-se a preocupação com a temperatura da água e também em se evitar processos de corrosão, a formação de depósitos, crescimento de microorganismos e formação de escumas, o que pode exigir a adição de produtos químicos para correção das características da água, onerando o seu uso;

- para o item "f" as características químicas são importantes pois deve ser eliminado o risco de corrosão ou depósitos superficiais sobre as peças;

- finalmente, para o item "b", usos em caldeiras e na geração de vapor, e item " $g$ " usos em processos industriais específicos, têm-se as possibilidades de reúso mais nobres porém, justamente é onde as características da água de reúso disponível podem exigir sistemas de tratamento avançados, conseqüentemente demandando maiores investimentos, o que pode inviabilizar o seu uso.

No caso de aplicação em processos industriais, item "g", é necessário ainda que não só a qualidade da água que será usada esteja dentro dos padrões exigidos pelo processo mas que se tenha estudado o risco que o uso dessa água pode introduzir 
caso se tenha vazamentos ou contato com equipamentos críticos ou mesmo com o produto (corrosão ou contaminação). Risco maior deve ser estudado quando se pensa na possibilidade de contato dessa água com operadores do processo ou mesmo com vazamento ao meio ambiente. Assim medidas preventivas devem ser cuidadosamente planejadas (MANCUSO; SANTOS, 2003).

\section{Uso racional e sustentável}

Quando se fala em uso racional e sustentável da água, a atenção deve ser direcionada para a forma de utilização deste recurso. Neste caso, a redução do consumo é um dos objetivos principais que deve ser buscado com todo o esforço, devendo ser consideradas as seguintes ações (MATSUMURA; MIERZWA, 2008):

- eliminar perdas físicas: identificar vazamentos em tubulações (válvulas, conexões, etc.).

- implantar melhorias na operação: colocação de hidrômetros para melhorar o controle de consumo, substituição de equipamentos por outros mais econômicos, verificar a possibilidade de usar resfriamento à $a r$.

- corrigir operações inadequadas: com o controle de consumo verificar se purgas em torres de resfriamento ou camisas de aquecimento, por exemplo, estão dentro do que é esperado para esses processos e se não está havendo desperdícios.

- evitar o uso de água de melhor qualidade para aplicações onde esta não é necessária.

É importante, então, o conhecimento dos processos e equipamentos para que uma avaliação criteriosa e ações de "caça aos desperdícios" possam ser conduzidas com sucesso. Muitas vezes é necessária a busca de novas tecnologias que possibilitem a substituição de equipamentos por outros de melhor desempenho em termos de consumo de água ou mesmo a instalação de dispositivos para redução do consumo (MIERZWA; HESPANHOL, 2005). 
A utilização de processos de produção e de sistemas de lavagem com baixo consumo de água deve ser estimulada desde a fase de projeto. Como exemplo, água de determinados processos como lavagem de filtros e de decantadores pode ser recuperada e reutilizada em outros processos, desde que atendam aos parâmetros de qualidade para estes.

Deve ser evitado o uso de água de qualidade superior em aplicações onde esta qualidade não é necessária. Exemplos de aplicações com menor restrição de qualidade são: o uso em sanitários; a utilização na lavagem de ruas e pátios; e uso na irrigação (MANCUSO; SANTOS, 2003).

As ações devem, também, ter foco no pessoal operacional, na medida em que melhor capacitação leva à execução de tarefas com regularidade e dentro de padrões pré-estabelecidos para as mesmas. Assim, treinamentos e campanhas de conscientização contra o desperdício devem ser realizados permanentemente (MIERZWA, 2005).

Conservação e racionalização no uso de água são ações que muitas vezes estão ao alcance nas operações industriais, não necessitando de tecnologias especiais. Por exemplo, a minimização e otimização do uso da água em processos de limpeza de reatores e containers para determinadas indústrias como a de detergentes e amaciantes podem ser obtidos com ações relativamente simples, que podem alcançar redução de 60 \% a 90 \% (ALVAREZ et al, 2004). Para isso é necessário:

- planejamento da produção visando minimizar o número de operações de limpezas entre lotes de fabricação;

- definição clara dos requisitos de qualidade que o processo de fabricação realmente exige para as operações de limpeza de reatores e tanques;

- o uso de novos procedimentos de limpeza que levem ao menor consumo de água.

Também é importante a minimização da quantidade de resíduos que a operação de limpeza deve retirar, como a utilização de ar comprimido como elemento de pré- 
limpeza. Isto, além de diminuir a quantidade de resíduos e a carga poluidora que deverá ser posteriormente tratada, pode ser um meio de recuperação de produto e diminuição de perdas (ALVAREZ et al, 2004).

Estudo realizado em indústria de semi-condutores em Taiwan demonstrou o uso de corrente de rejeito originada de tratamento de água por membranas de osmose reversa em aplicações como: reposição em sistemas de torres para ar condicionado, usos na limpeza de pisos e ambientes e em banheiros. Esse tipo de indústria necessita de água ultrapura para a produção de placas eletrônicas, obtida por sistema de membranas de osmose reversa que utiliza água potável já com baixa presença de sais. Assim, mesmo com o sistema de purificação operando com uma taxa de recuperação de $70 \%$, obtém-se um fluxo de rejeito com concentração de sais que permite as aplicações listadas (YOU et al., 2001).

Nas indústrias de alimentos, onde o uso intensivo de água é uma também necessidade assim como na indústria de cosméticos, estudos foram conduzidos visando o reuso de efluentes. Sarkar et al. (2006) conduziu um trabalho de investigação das possibilidades de melhoria da qualidade dos efluentes através de pré-tratamento com coagulantes e filtração em carvão ativo, visando remoção de cor e odores, seguido de tratamento pela passagem em sistema de membranas de osmose reversa. Embora o estudo não leve em conta os custos de tal processo de tratamento, é uma opção tecnologicamente possível que dependerá da necessidade e disponibilidade do recurso água para uma dada empresa e o preço que se pretende pagar pelas alternativas disponíveis.

O principal agente motivador para a melhoria da eficiência no uso de água em uma indústria é o aumento do custo da água, e o principal indicador dessa eficiência é o índice de consumo pela produção realizada. O custo da água em uma empresa deve levar em conta a quantidade de água consumida, a quantidade de efluentes gerados e que devem ser tratados, além de outros custos relacionados a obtenção da água e o tratamento de efluentes. (DVARIONIENE; STASISKIENE, 2007).

O índice de consumo de água pela produção realizada e o custo da água são a base da ferramenta de modelagem para gerenciamento integrado dos recursos de água, 
que pode ser usada pelas empresas para avaliação e busca de maior eficiência do consumo de água (DVARIONIENE; STASISKIENE, 2007).

Quando se fala em gestão hídrica em indústria, logo se pensa em processos independentes e não relacionados: tratamentos para obtenção de água de qualidade, usos da água nos processos industriais e tratamento para os efluentes gerados ao fim dos processos de fabricação. Esse conceito de tratamento final, chamado de tratamento de fim de tubo, mais conhecido em sua forma em inglês como "end of pipe treatment" é o procedimento geralmente adotado pelas empresas em que todos os fluxos de saída de processos de fabricação são encaminhados a um só local, a estação de tratamento de efluentes, onde o tratamento empregado visa adequar esses efluentes aos padrões de lançamento determinados pela legislação ambiental (ZOTTER, 2004).

O tratamento de fim de tubo possui uma vantagem que deve ser colocada: promove a separação eficiente dos efluentes direcionando-os logo que gerados ao local de tratamento, separando-os dos processos de produção. Outra vantagem apregoada é que por ser independente dos processos de produção, em caso de falha do sistema de tratamento o setor produtivo não é afetado a princípio, sendo possível que até continue operando enquanto os efluentes são desviados ou armazenados temporariamente. Também se considera que as soluções tipo fim de tubo já estão bastante conhecidas e madura tecnologicamente de modo que se tornam mais seguras e confiáveis.

Entretanto os sistemas tipo fim de tubo são mais dispendiosos em termos de consumo de energia e insumos para a sua operação. Embora se tenha como principal objetivo o atendimento à legislação para os efluentes lançados, do ponto de vista ambiental esse maior consumo de energia e de insumos não é adequado pois gera maiores impactos ao meio ambiente (ZOTTER, 2004). Também uma vez instalados não permitem muitas mudanças e alterações sem que grandes investimentos financeiros sejam feitos.

Assim, um outro enfoque para o gerenciamento hídrico pode ser aplicado em que se leve em conta os processos de solução integrada. Essas soluções integradas devem incluir os conceitos de reciclagem, modernização e implementação de melhorias nos 
processos. Com isso se tem como principal objetivo aliado ao atendimento legal, a redução da geração de efluentes nos processos além da própria redução do consumo de água na empresa.

Um exemplo disso é o reúso de efluentes para finalidades menos exigentes dentro da própria empresa, em substituição a água de melhor qualidade, que diminui o lançamento de efluentes aos corpos d'água e leva à economia no consumo de água de boa qualidade. De forma simplificada seria o uso de correntes que saem de um processo, dependendo de suas características e quantidades, sendo utilizadas em outro com economia e eficiência.

Evidentemente soluções integradas exigem um conhecimento melhor de todo o processo produtivo e das características da água necessária a cada etapa desse processo. Também é necessário um controle rigoroso em todo o sistema bem como processos de manutenção preventiva adequados.

Existem riscos que devem ser prevenidos como a possibilidade de contaminação de produtos ou mesmo o do contato do Homem com água de qualidade comprometida mas que está sendo utilizada em substituição a de boa qualidade. É para isso que devem ser aplicadas novas tecnologias que garantam a separação necessária, controles rigorosos e evitem falhas e deterioração em equipamentos.

\subsection{Padrões de qualidade}

Padrões de qualidade para água potável e que são utilizadas nos processos industriais e uso doméstico são estabelecidos por entidades como a americana EPA - Environmental Protection Agency, no seu documento Drinking Water Standards. e, principalmente, pela Organização Mundial de Saúde, como no documento Guideline for Drinking-water Quality (WHO, 2008). No Brasil, a Portaria $n^{\circ}$ 518, de 25 de março de 2004 do Ministério da Saúde, define os padrões de potabilidade da água para consumo humano. 
Para água de reúso existe grande dificuldade em se ter padrões estabelecidos em normas legais pois isto depende das aplicações que se pretende dar a essa água, das possibilidades de contato das pessoas, e como ela pode afetar o meio ambiente. Outra questão importante está relacionada à aceitação pelo público.

Geralmente os padrões estabelecidos visam a proteção das pessoas ao contato ou ingestão de águas com possibilidade de alguma contaminação com águas de reuso, especialmente quando essa água tem origem em esgotos sanitários e pode ser aplicada na agricultura ou devolvida aos corpos hídricos, e não especificamente quando aplicadas em processos industriais. Exemplo disso é encontrado no documento Guidelines for the safe use for wastewater, excreta and graywater, da Organização Mundial da Saúde (WHO, 2006).

Também o documento da Environmental Protection Agency denominado Guidelines for water reuse (2004), estabelece critérios que podem ser usados dentro de determinadas situações. As possibilidades de contato humano com a água de reúso podem ser listadas como (EPA, 2004):

- contato por ingestão direta;

- contato por ingestão de alimentos crus e verduras consumidos crus e que foram irrigados por água de reúso;

- contato por ingestão de alimentos processados/industrializados mas que foram irrigados com água de reúso;

- contato direto da pele com águas contaminadas por águas de reúso, com o de lagos e rios;

- contato por inalação de aerossóis devido a aspersão em sistemas de irrigação ou mesmo de sistemas de torres de resfriamento.

Assim, levando-se em conta esse risco, todo projeto de sistema de reúso deve obedecer aos seguintes critérios para a qualidade (WHO, 2008): 
$1^{\circ}$ Questão da Saúde Pública - a exposição e nível de contato humano exige maior cuidado com a segurança sanitária, sendo necessária a desinfecção e manutenção de residual de cloro na água de reúso;

$2^{\circ}$ Aceitação da água - a água não deve apresentar comprometimento estético (cor, turbidez ou odores) que cause objeção.

$3^{\circ}$ Preservação do ambiente - especialmente quando utilizada para a recomposição de lagos ou outros fins paisagísticos em contato direto com o meio ambiente, não pode conter elementos que causem alteração do ecossistema (excesso de nutrientes ou contaminantes nocivos) ou geração de odores desagradáveis, etc.;

$4^{\circ}$ Qualidade da fonte de água - é importante que os efluentes a serem tratados e o próprio tratamento mantenham-se dentro dos padrões esperados, evitando-se o comprometimento das águas que serão utilizadas como reúso;

$5^{\circ}$ Adequação ao uso pretendido - em função da aplicação pretendida deve-se ter um padrão definido levando em conta, não os aspectos sanitários, mas, também, as necessidades específicas, sejam para processos industriais ou qualquer outra finalidade, inclusive evitando que se tenha desperdício com tratamentos adicionais que elevem a qualidade a níveis acima do que é exigido para a aplicação, porém sem provocar danos e deterioração aos equipamentos que tenham contato com essa água. 


\section{METODOLOGIA}

Este trabalho foi baseado em um estudo de caso de uso de água em uma indústria de cosméticos.

A utilização do recurso água na indústria, sua obtenção e tratamentos necessários, bem como as técnicas de conservação foram estudadas, sendo o trabalho desenvolvido seguindo as etapas abaixo indicadas:

a) busca de informações e referências bibliográficas sobre o tema conservação e reúso de água, bem como sobre os processos de obtenção e tratamento de água e de efluentes;

b) avaliação da documentação disponível na empresa objeto do estudo, tais como relatórios de análise de qualidade de águas e efluentes, desenhos e plantas, manuais de operação, instruções de trabalho e manuais técnicos de equipamentos, relatórios de desempenho industrial;

c) inspeções e avaliações de campo nas instalações industriais, acompanhando operações normalmente executadas;

d) entrevistas com o pessoal de operação nas áreas de produção bem como com o pessoal de engenharia de processos, pessoal de operação de ETA/ETE, com coleta e compilação das informações obtidas;

e) elaboração de diagramas, fluxogramas, balanços de massa utilizando os dados obtidos dos hidrômetros implantados nos diversos setores de consumo, descrição de operações e de processos, bem como descrição de equipamentos;

f) acompanhamento das operações de fabricação de produtos cosméticos e demais atividades relacionadas nos setores de produção;

g) descrição das práticas de conservação e reúso já aplicadas pela empresa; 
h) elaboração de propostas que possam levar à redução de consumo de água e sua conservação nos processos analisados.

Os dados para a elaboração do balanço hídrico foram obtidos a partir das medições de 14 hidrômetros, classe metrológica $B$, instalados nas principais edificações da Natura, com vazões nominais $(Q n)$ variando de 5 a $15 \mathrm{~m}^{3} / \mathrm{h}$, além dos três já existentes para o poço artesiano e caixa d'água, conforme tabela 4.1:

Tabela 4.1 - Lista dos hidrômetros instalados

\begin{tabular}{lccc}
\hline \multicolumn{1}{c}{ Local } & Quantidade & Marca & $\begin{array}{c}\text { Vazão nominal } \\
\mathbf{Q n} \\
\left(\mathbf{m}^{\mathbf{3}} \mathbf{/ h}\right)\end{array}$ \\
\hline 1. Poço artesiano & 1 & Tecnobrás & 45 \\
\hline 2. Caixa d'água & 2 & LAO & 150 \\
\hline 3. Fábrica 1 & 2 & LAO & 15 \\
\hline 4. Fábrica 2 & 2 & LAO & 15 \\
\hline 5. Fábrica 3 & 2 & LAO & 15 \\
\hline 6. Caldeiras & 1 & LAO & 5 \\
\hline 7. Prédio P\&D/NAN & 1 & LAO & 10 \\
\hline 8. Prédio da Engenharia & 1 & LAO & 10 \\
\hline 9. Prédio do Picking & 1 & LAO & 10 \\
\hline 10. Prédio de Serviços & 2 & LAO & 10 \\
\hline 11. Clube & 1 & LAO & 5 \\
\hline 12. Portaria & 1 & LAO & 5 \\
\hline
\end{tabular}

As informações sobre a empresa foram organizadas como abaixo:

- Identificação da empresa.

- Identificação dos processos de produção empregados.

- Identificação das fontes de água utilizadas na empresa e como é realizado o seu tratamento.

- Caracterização e padrões de qualidade da água necessária aos diferentes processos, industriais ou não. 
- Identificação do tratamento empregado para os efluentes gerados nesses processos industriais bem como para os efluentes domésticos gerados pelos empregados e áreas não produtivas.

- Levantamento do balanço de consumo de água dos processos.

- Identificação dos processos com maior consumo de água através da análise do histórico de medições dos volumes consumidos (hidrômetros e balanços hídricos).

- Identificação dos processos com consumo de água de qualidade superior à necessária.

- Detalhamento das formas de utilização das águas nesses processos com maior consumo.

- Identificação das possibilidades de otimização do consumo, conservação ou reúso de água nesses processos.

- Levantamento das vantagens e ganhos de um programa de conservação e uso racional de água, aplicado a esses processos. 


\section{INFORMAÇÕES SOBRE A EMPRESA}

\subsection{Identificação e informações sobre a empresa}

A Indústria e Comércio de Cosméticos Natura Ltda. dedica-se à produção de produtos de perfumaria e cosméticos em geral. Sua unidade industrial situa-se no município de Cajamar - SP, no km 30,5 da Rodovia Anhanguera.

Esta unidade envolve um complexo industrial integrado de fabricação, distribuição, administração e treinamento, ocupando uma área de aproximadamente $88.000 \mathrm{~m}^{2}$, em terreno de aproximadamente $680.000 \mathrm{~m}^{2}$, onde 4.200 pessoas trabalham, entre empregados da empresa e contratados de empresas prestadoras de serviços. $\mathrm{O}$ regime de produção é em 3 turnos diários.

A produção média mensal atingiu em dezembro de 2008 cerca de 22 milhões de unidades/mês, com um portfólio de cerca de 1.000 produtos diferentes.

Esses produtos possuem características bastante distintas, podendo ser:

- sólidos: pós-compactos e batons,

- pastosos: cremes, géis, "gloss" labiais e condicionadores,

- líquidos: como colônias, perfumes, desodorantes, xampús e óleos.

Também os volumes contidos nas embalagens dos itens produzidos são bastante variáveis, de poucos mililitros, como o produto "gloss labial", a até $400 \mathrm{~mL}$, como os frascos de condicionadores e xampús. Considerando ainda os produtos sólidos, fica evidente a dificuldade em se quantificar a soma desses itens produzidos em termos volumétricos.

$\mathrm{Na}$ Unidade Cajamar, não se tem rede pública de abastecimento de água disponível e, apesar de sua propriedade ser cortada por um rio Classe 2 - Rio Juquery, este não possui vazão regular e suficiente para atendimento às necessidades do 
empreendimento. Assim a empresa obtém a água através de poços profundos, sendo consumidos cerca de $124.000 \mathrm{~m}^{3}$ /ano.

Os seus processos de produção e a população de empregados geraram em 2008:

- $44.811 \mathrm{~m}^{3} / a n o$ de efluentes industriais; e

- $43.351 \mathrm{~m}^{3} /$ ano de efluentes sanitários.

Esses efluentes totalizaram então $88.162 \mathrm{~m}^{3} / \mathrm{ann}$, que foram tratados na Estação de Tratamento de Efluentes.

Atualmente, aproximadamente $55 \%$ do efluente tratado é utilizado como água de reúso, sendo que os 45 \% sem aplicação são dispostos no Rio Juquery.

\subsection{1 Áreas administrativas}

As áreas administrativas estão divididas em diversas edificações onde se têm atividades típicas de escritórios:

- Prédio do Centro de Inovação, que agrupa as áreas de Pesquisa e Desenvolvimento de Produtos, Desenvolvimento de Embalagens, Engenharia de Processos e Marketing de Produtos.

- Prédio de Operações e Logística com os setores de Planejamento e Controle Logístico, Auditoria, Comunicações, Financeiro, Suprimentos e Diretorias.

- Prédio de Serviços com as áreas de Recursos Humanos, Restaurante, Ambulatório Médico e Berçário.

- Prédio do Centro de Convenções e Treinamento, onde se tem atividades diversas voltadas ao treinamento de empregados e eventos ao público interno e externo. 


\subsubsection{Setores industriais}

A área industrial é segmentada em 3 unidades, em edificações diferentes, separadas de acordo com os seus processos industriais e operações necessárias a produção de itens com características e exigências semelhantes, tais como critérios de qualidade, viscosidade, tipo de aplicação do cosmético e formulações básicas. Assim se tem:

- Fábrica 1 - fabricação de perfumes, colônias, desodorantes e óleos;

- Fábrica 2 - fabricação de produtos para cabelos, condicionadores, sabonetes líquidos e cremes;

- Fábrica 3 - fabricação de produtos para tratamento de pele e maquilagem, pós-compactos, máscaras e batons.

Além dessas edificações, na área industrial tem-se ainda:

- a Central de Utilidades com geração de vapor e água gelada;

- a área de Armazenamento, Separação e Distribuição dos produtos fabricados;

- a Tancagem onde se armazenam matérias primas a granel;

- a Central de Resíduos onde se separam os diversos resíduos sólidos gerados pela empresa, para reciclagem e destinação final;

- a ETA - Estação de Tratamento de Água, onde é obtida e tratada a água extraída do poço artesiano que é consumida na empresa, e a ETE - Estação de Tratamento de Efluentes, onde são tratados todos os efluentes gerados (industriais e sanitários). 


\subsection{Processos de produção}

\subsubsection{Fabricação de cosméticos}

Em geral os processos de fabricação de cosméticos se realizam em "batelada". Apesar dos equipamentos utilizados na preparação os diversos cosméticos serem chamados de "reatores", a maioria dos processos são operações unitárias de mistura, homogeneização, separação, aquecimento ou resfriamento.

Assim esses reatores são tanques dotados de diversos recursos de agitação e mistura dos componentes das fórmulas, possuindo sistemas de aquecimento ou resfriamento em camisa, alimentação de matérias primas por tubulações ou por sistemas por sucção a vácuo. As temperaturas empregadas não ultrapassam $80^{\circ} \mathrm{C}$, evitando-se, assim, a degradação térmica de matérias-primas sensíveis ao calor. Geralmente, as operações se realizam a pressão atmosférica.

Todos os equipamentos que podem ter contato com as matérias-primas ou produtos são em aço inox $316 \mathrm{~L}$.

A água empregada e incorporada aos produtos deve ser desmineralizada, através de processo de troca iônica, ou produzida por sistema de osmose reversa a partir da água potável, produzida por sua vez na ETA - Estação de Tratamento de Água.

As matérias-primas a granel como etanol, óleos vegetais e tensoativos são armazenadas em tanques em aço inox $316 \mathrm{~L}$ no Parque de Tanques, sendo bombeadas diretamente aos reatores, conforme as formulações contidas nas "ordens de produção".

As outras matérias-primas são recebidas embaladas em sacos, barricas ou caixas, no caso de material sólido, granulado ou em pó. Para líquidos, em tambores plásticos ou metálicos de diversas capacidades.

Essas matérias-primas, que serão pesadas nas quantidades estipuladas pela formulação, geralmente, não passam por nenhum pré-tratamento. No entanto, algumas necessitam ser fluidificadas, visando melhorar a sua adição, mistura e 
incorporação ao produto em fabricação. É o caso de materiais sólidos, que devem ser previamente dissolvidos em um solvente (água, álcool ou óleos), ou materiais graxos solidificados, que devem ser fundidos em banho-maria para serem utilizados.

Basicamente as principais operações na fase de fabricação consistem das seguintes etapas e atividades:

1. Limpeza e sanitização do reator de fabricação ("set up");

2. Pesagem das matérias-primas fracionadas em recipientes diversos;

3. Adição das matérias-primas pesadas na etapa anterior e de água purificada (água desmineralizada ou produzida por osmose reversa) ao reator de fabricação;

4. Aquecimento ou resfriamento com agitação, conforme as necessidades do processo de fabricação do produto;

5. Recirculação em homogeneizadores (se necessário);

6. Controle físico-químico (cor, viscosidade, pH, etc.) e depois controle microbiológico do produto final;

7. Transferência para tanque de armazenamento onde o produto final aguarda o resultado das análises físico-químicas e microbiológicas;

8. Envio para o setor de envase, onde o produto é envasado em frascos, potes ou bisnagas.

Após a etapa 8 , os equipamentos utilizados, reatores, tanques, tubulações e máquinas de envase são submetidas ao processo de limpeza e sanitização, etapa 1.

\subsubsection{Envase e embalagem dos cosméticos}

Do tanque de armazenamento o produto segue por gravidade ou bombeamento para as linhas de envase e embalagem onde ocorre:

1. O envase em frascos, potes ou bisnagas; 
2. Fechamento dos frascos, potes ou bisnagas;

3. Rotulagem e etiquetagem dos frascos / potes / bisnagas;

4. Colocação dos frascos / potes / bisnagas em cartuchos ou embalagens específicas;

5. Celofanagem (proteção com filme termo encolhível);

6. Encaixotamento em caixas de papelão;

7. Paletização das caixas;

8. Envio dos "pallets" para o setor de armazenagem e posterior distribuição. 


\section{RESULTADOS E DISCUSSÃO}

\subsection{Avaliação do histórico do consumo de água no setor industrial}

No levantamento de informações sobre o histórico de consumo de água na empresa verificou-se uma sensível diminuição no consumo por item produzido.

A figura 6.1 apresenta a evolução do consumo relativo de água no setor de produção da empresa em estudo, em volume (L) por unidade produzida, considerando-se o consumo total, ou seja, a água incorporada ao produto e a que é consumida nos processos industriais.

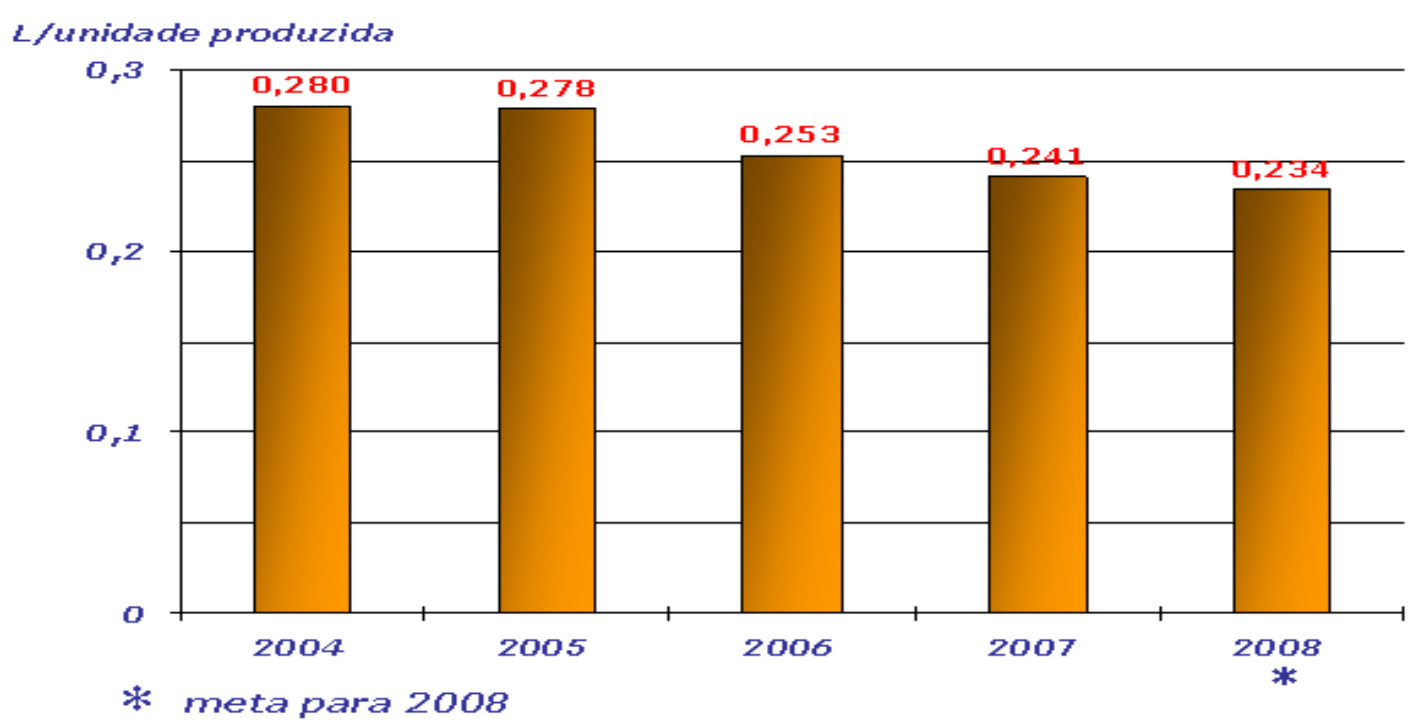

Figura 6.1 - Evolução do consumo de água relativo em L/unidade produzida Fonte: (NATURA, 2008 e Relatórios de Indicadores Industriais)

A figura 6.2 mostra a evolução do consumo total na empresa em estudo, considerando a unidade industrial de Cajamar, bem como o consumo para atendimento aos setores não industriais. 


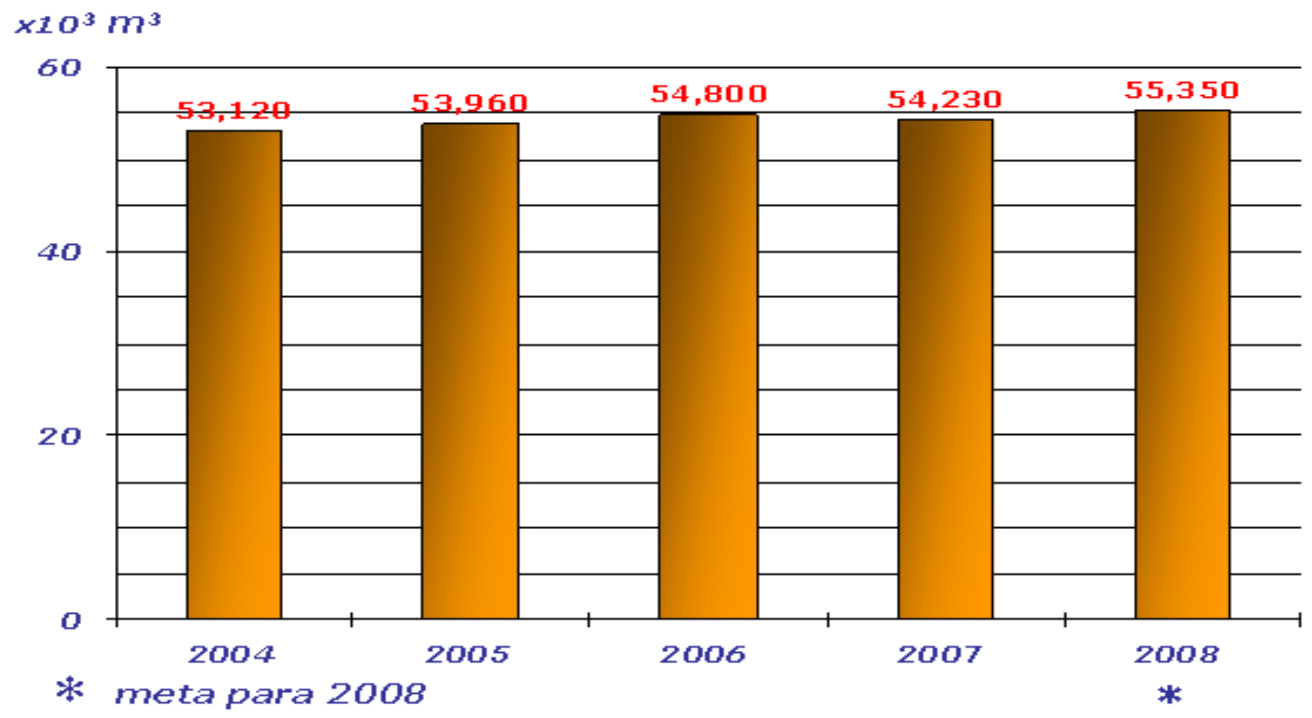

Figura 6.2 - Evolução do consumo de água total em $\times 10^{3} \mathrm{~m}^{3}$ Fonte: (NATURA, 2008 e Relatórios de Indicadores Industriais)

Comparando-se os dois gráficos percebe-se o aumento de consumo total, que se justifica pelo aumento do volume de produtos fabricados (Figura 6.3) e aumento do número de empregados ao longo dos anos (Figura 6.4). Entretanto, durante o mesmo período, o consumo por unidade produzida teve um decréscimo, em função da otimização da utilização da água e também pelo ganho de escala que levou a uma melhor eficiência no consumo.

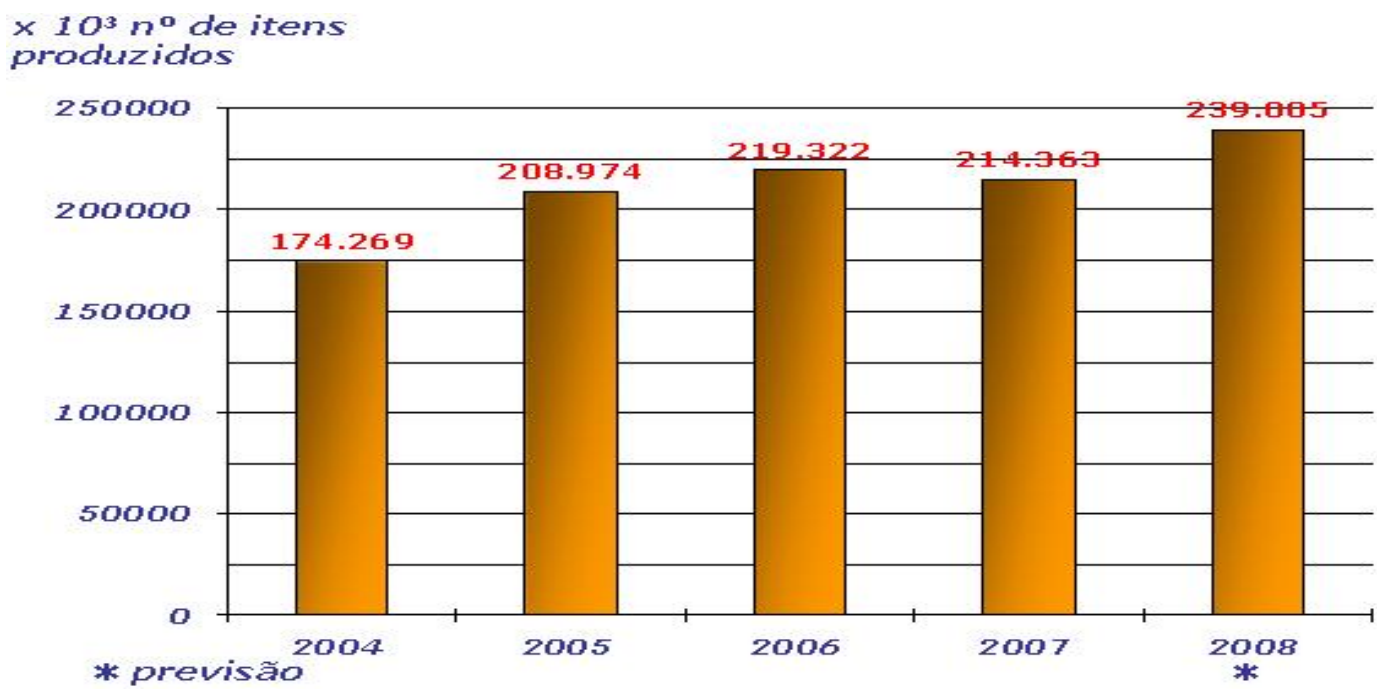

Figura 6.3 - Crescimento da produção de cosméticos

Fonte: (NATURA, 2008 e Relatórios de Indicadores Industriais) 
$n^{\circ}$ de

colaboradores

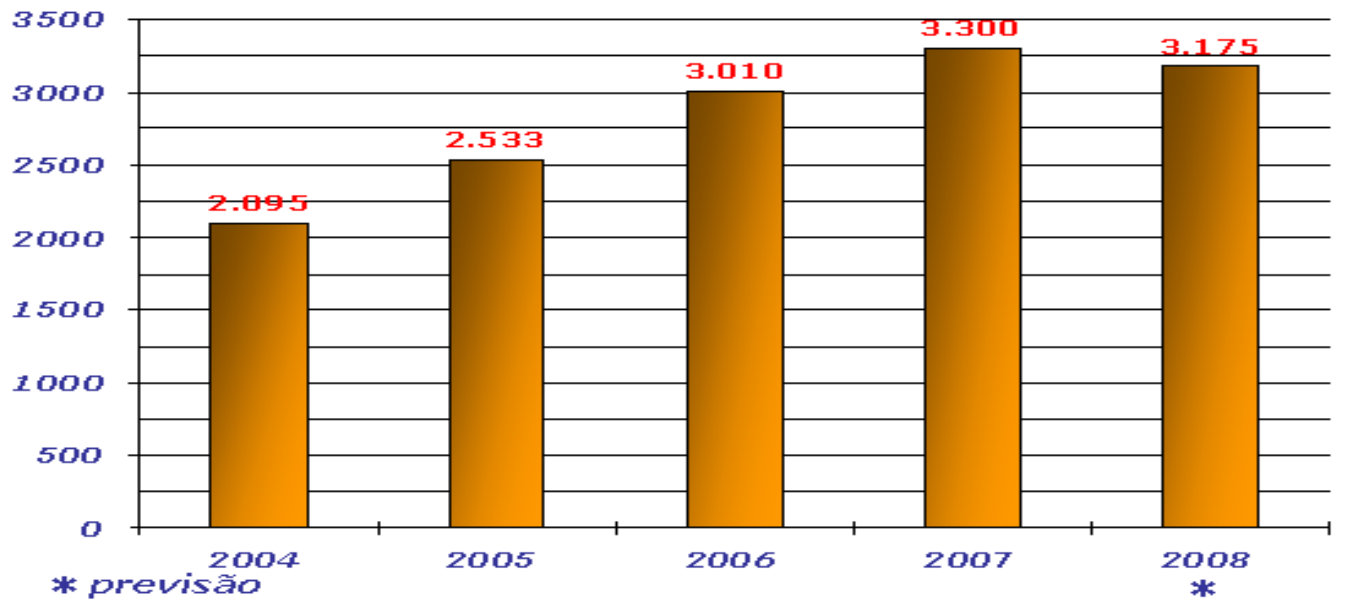

Figura 6.4 - Crescimento do número de empregados Fonte: (NATURA, 2008 e Relatórios de Indicadores Industriais)

\subsection{Identificação de fontes de água e tratamento empregado}

A empresa é abastecida por água de poço profundo, sendo que a outorga concedida à empresa pelo Departamento de Águas e Energia Elétrica do Estado de São Paulo - DAEE permite a extração de até $400 \mathrm{~m}^{3} /$ dia do lençol freático $\left(20 \mathrm{~m}^{3} / \mathrm{h}\right.$ por até 20 h). Também possui um poço reserva com outorga para extração de $15 \mathrm{~m}^{3} / \mathrm{h}$ por até $20 \mathrm{~h})$.

A necessidade média de água, atualmente, para o desenvolvimento dos processos industriais e para o consumo em geral exige, em termos de vazão de produção do poço, cerca de $14 \mathrm{~m}^{3} / \mathrm{h}$.

A água produzida pelo poço artesiano passa por processo de cloração e filtração visando garantir sua potabilidade, especialmente do ponto de vista microbiológico (Figura 6.5). Assim tem-se que:

- Cloração: realizado por adição de dióxido de cloro, que utiliza sistema que mistura de forma controlada e automatizada ácido clorídrico a 9\% 
e clorito de sódio a 7,5\%, que é injetado ao fluxo de água, figura 6.7. A dosagem empregada é de $0,20 \mathrm{mg} / \mathrm{L}$;

- Filtração: em filtro de areia, figura 6.6;

- Reservação em caixa d'água vertical com 4 segmentos de $200 \mathrm{~m}^{3}$ para distribuição a diferentes setores da empresa (Figura 6.5);

- Distribuição aos pontos de consumo.

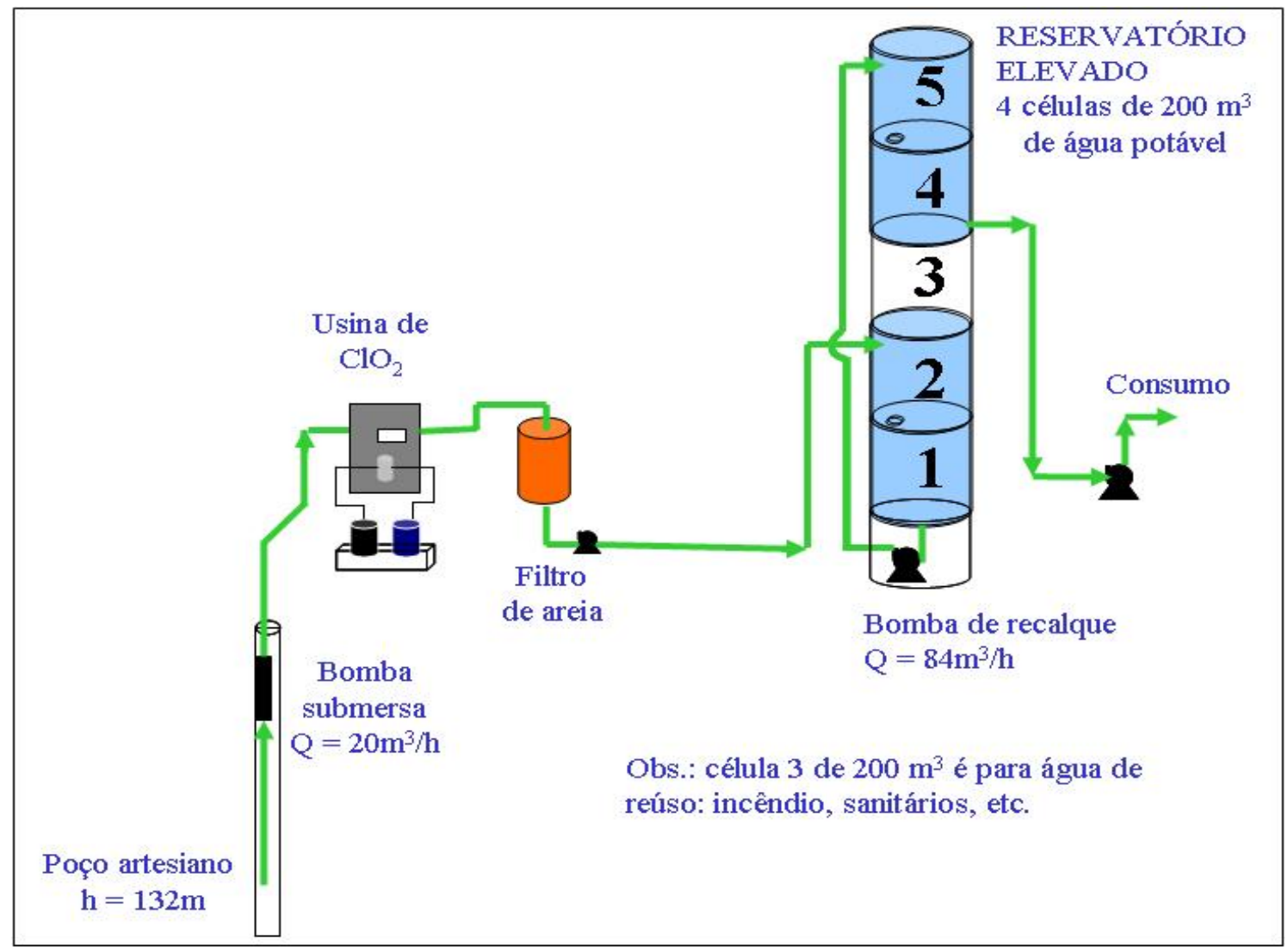

Figura 6.5 - Diagrama simplificado do sistema de captação, tratamento e reservação de água 


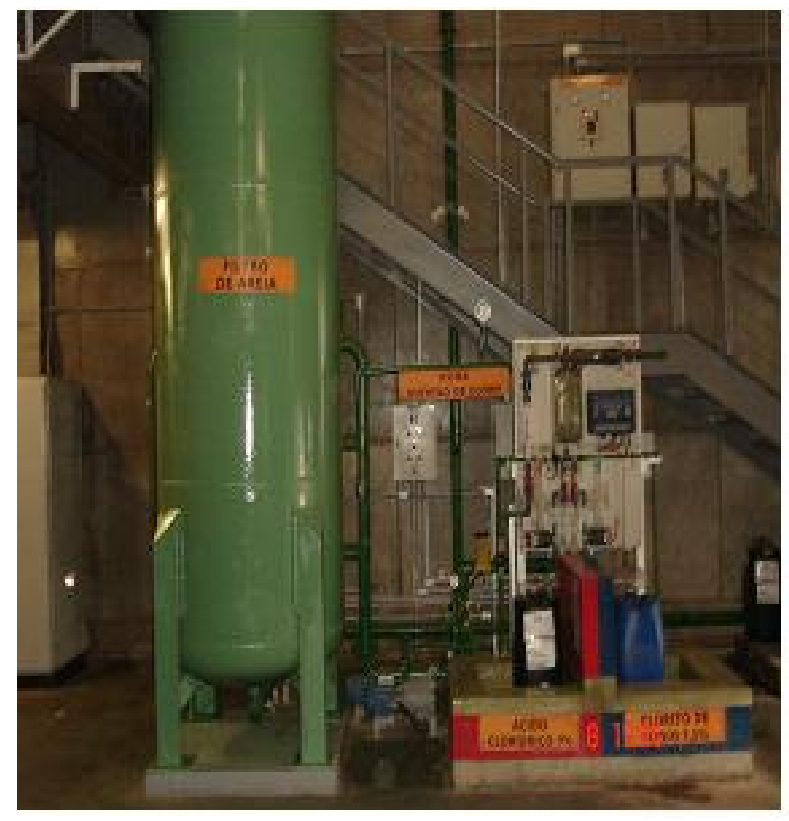

Figura 6.6 - Filtro de areia

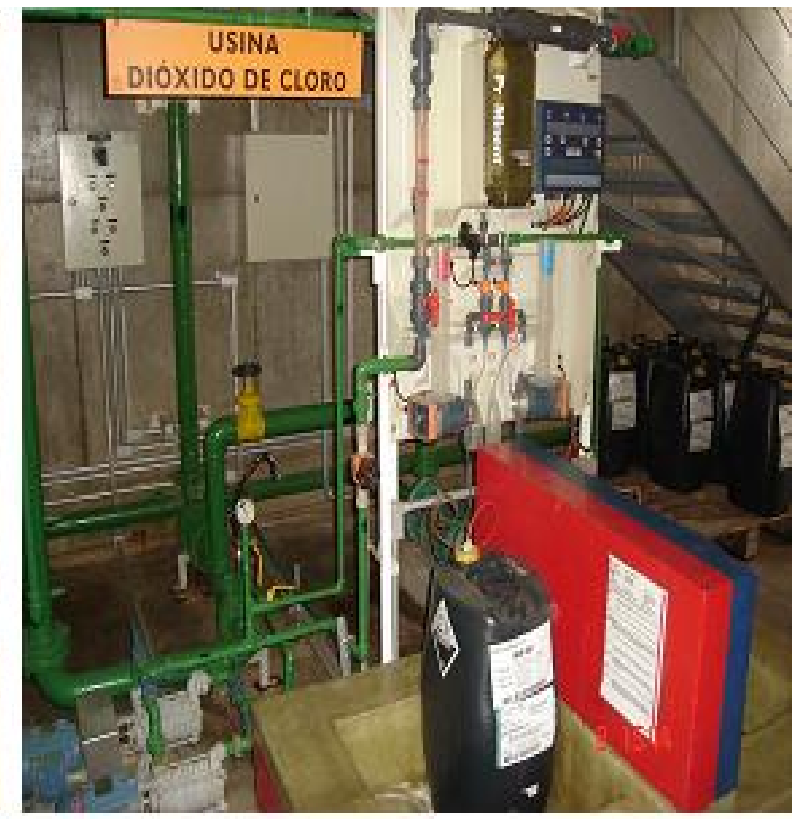

Figura 6.7 - Usina de $\mathrm{ClO}_{2}$

A água potável produzida atende aos requisitos da Portaria $n^{\circ} 518$ do Ministério da Saúde, conforme resultados dos principais parâmetros obtidos de análises rotineiras realizadas pelo próprio laboratório da empresa, com freqüência semanal, cujos valores médios no período de julho a outubro de 2008 estão apresentados na tabela 6.1:

Tabela 6.1 - Resultado das análises da água potável produzida na ETA no período de julho a outubro de 2008.

\begin{tabular}{lllll}
\hline \multicolumn{1}{c}{$\begin{array}{c}\text { Parâmetro de } \\
\text { Potabilidade }\end{array}$} & \multicolumn{1}{c}{ Unidade } & \multicolumn{1}{c}{$\begin{array}{c}\text { Padrão Port. } \\
\mathbf{5 1 8}\end{array}$} & \multicolumn{1}{c}{ Resultado } & \multicolumn{1}{c}{$\begin{array}{c}\text { Desvio } \\
\text { Padrão }\end{array}$} \\
\hline Coliformes Totais & $\mathrm{NMP} / 100 \mathrm{~mL}$ & Ausente & Ausente & $\mathrm{NA}$ \\
\hline $\begin{array}{l}\text { Coliformes Fecais } \\
\text { Contagem padrão }\end{array}$ & $\mathrm{NMP} / 100 \mathrm{~mL}$ & Ausente & Ausente & $\mathrm{NA}$ \\
$\begin{array}{l}\text { de bactérias } \\
\text { heterotróficas }\end{array}$ & $\mathrm{UFC} / \mathrm{mL}$ & 500 & ausente & $\mathrm{NC}$ \\
\hline $\begin{array}{l}\text { Cianotoxinas } \\
\text { (Microcistinas) }\end{array}$ & $\mu \mathrm{g} / \mathrm{L}$ & 1 & $<\mathbf{0 , 5}$ & $\mathrm{NC}$ \\
\hline $\mathrm{pH}$ & $\mathrm{pH}$ & $6,0-9,5$ & $\mathbf{7 , 8}$ & 0,3 \\
\hline Amônia & $\mathrm{mg} / \mathrm{L}$ & 1,5 & $\mathbf{0 , 1}$ & $\mathrm{NC}$ \\
\hline
\end{tabular}


Tabela 6.1 - Resultado das análises da água potável produzida na ETA no período de julho a outubro de 2008 (continuação)

\begin{tabular}{lllll}
\hline $\begin{array}{c}\text { Parâmetro de } \\
\text { Potabilidade }\end{array}$ & \multicolumn{1}{c}{ Unidade } & \multicolumn{1}{c}{$\begin{array}{c}\text { Padrão Port. } \\
\mathbf{5 1 8}\end{array}$} & \multicolumn{1}{c}{ Resultado } & \multicolumn{1}{c}{$\begin{array}{c}\text { Desvio } \\
\text { Padrão }\end{array}$} \\
\hline Alumínio & $\mathrm{mg} / \mathrm{L}$ & 0,2 & $\mathbf{0 , 0 2 5}$ & 0,012 \\
\hline Cloreto & $\mathrm{mg} \mathrm{Cl} / \mathrm{L}$ & 250 & $\mathbf{1 2 , 5}$ & 1,2 \\
\hline Cor & Hazen & 15 & $\mathbf{5}$ & $\mathrm{NC}$ \\
\hline Dureza total & $\mathrm{mg} \mathrm{CaCO} / \mathrm{L}$ & 500 & $\mathbf{7 4}$ & 5,1 \\
\hline Ferro & $\mathrm{mg} / \mathrm{L}$ & 0,3 & $\mathbf{0 , 0 1}$ & 0,01 \\
\hline Manganês & $\mathrm{mg} / \mathrm{L}$ & 0,1 & $\mathbf{0 , 0 1}$ & 0,002 \\
\hline Odor & --- & $\mathrm{Não}$ objetável & $\mathbf{N a ̃ o ~ o b j e t a ́ v e l ~}$ & $\mathrm{NA}$ \\
\hline Gosto & --- & $\mathrm{Não}$ objetável & $\mathbf{N a ̃ o}$ objetável & $\mathrm{NA}$ \\
\hline Sódio & $\mathrm{mg} / \mathrm{L}$ & 200 & $\mathbf{5 , 7}$ & 1,7 \\
\hline $\begin{array}{l}\text { Sólidos dissolvidos } \\
\text { totais }\end{array}$ & $\mathrm{mg} / \mathrm{L}$ & 1000 & $\mathbf{3 6}$ & 17 \\
\hline Sulfato & $\mathrm{mg} \mathrm{SO} / \mathrm{L}$ & 250 & $\mathbf{3 , 1}$ & 1,2 \\
\hline $\begin{array}{l}\text { Sulfeto (como } \\
\mathrm{H}_{2} \mathrm{~S} \text { ). }\end{array}$ & $\mathrm{mg} / \mathrm{L}$ & 0,05 & $<\mathbf{0 , 0 5}$ & $\mathrm{NC}$ \\
\hline Surfactantes & $\mathrm{mg} / \mathrm{L}$ & 0,5 & & $\mathrm{NC}$ \\
\hline Turbidez & $\mathrm{UNT}$ & 5 & $\mathbf{0 , 1}$ & 0,02 \\
\hline
\end{tabular}

NA - não aplicável NC - não calculado, valores abaixo do nível de detecção

Fonte: (Relatórios internos da empresa de análises de água potável)

Deve-se considerar que a água utilizada nos equipamentos de processo em geral, tais como trocadores de calor, torres de refrigeração, lavagem de equipamentos e alimentação da caldeira, é a mesma água potável produzida na ETA, apenas sua reservação na caixa d'água vertical, bem como sua distribuição, são realizadas separadamente. Essa água é também chamada de "água potável industrial".

A partir dessa água potável obtém-se a "água purificada" ou "água desmineralizada", utilizada para incorporação ao produto ou lavagem (enxágüe final de equipamentos), que pode ser produzida por passagem em leitos de resina de troca iônica ou por osmose reversa.

\subsection{Caracterização e padrões de qualidade da água}

A água potável, produzida na ETA, é utilizada na maioria das atividades desenvolvidas na empresa, com exceção da água que é incorporada aos produtos, 
que deve, obrigatoriamente, ser purificada (desmineralizada ou deionizada), pois os íons presentes na água potável podem reagir com os componentes das fórmulas de preparação dos cosméticos, causando alteração de sua qualidade.

Mesmo nas atividades de lavagem e limpeza, especialmente na fase final de enxágüe é utilizada água desmineralizada, evitando-se a potencial contaminação do produto final. Assim essa água purificada é produzida de duas formas: sistema de desmineralização por troca iônica ou sistema de purificação por osmose reversa.

\section{Produção de água desmineralizada por troca iônica}

A água purificada é produzida por uma instalação de desmineralização por passagem em colunas de troca iônica cujas etapas estão relacionadas abaixo e são representadas no diagrama da figura 6.8:

- filtração em areia;

- demineralização em leito misto;

- armazenamento;

- desinfecção por UV em ciclo fechado;

- distribuição para as áreas de produção.

O padrão estabelecido para essa água purificada é de no máximo $3,0 \mu \mathrm{S} / \mathrm{cm}$ a $20^{\circ} \mathrm{C}$. 


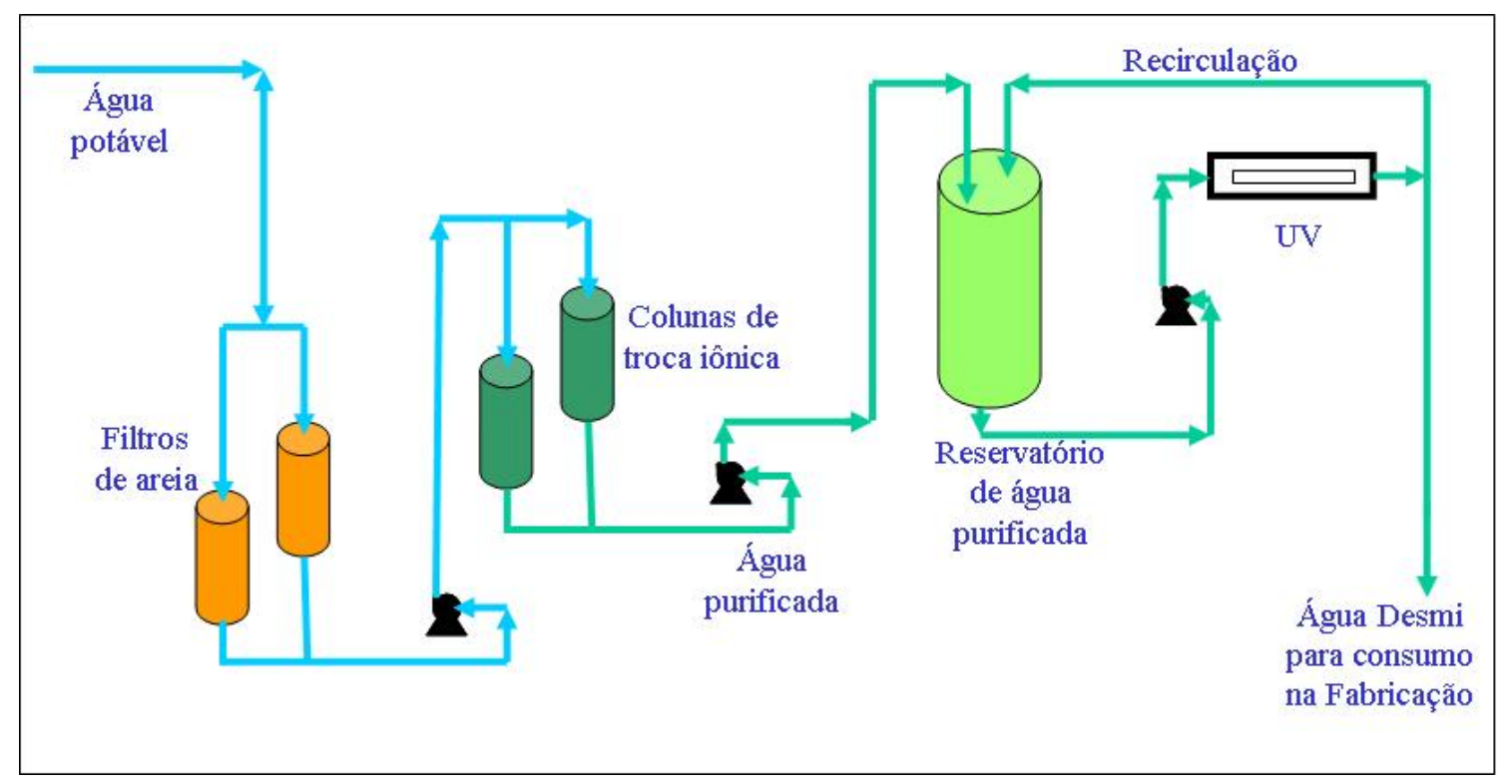

Figura 6.8 - Diagrama simplificado do sistema de desmineralização de água (elaborado pelo autor)

\section{$\underline{\text { Produção de água desmineralizada por osmose reversa }}$}

Para a Fábrica 2 é utilizado processo de produção de água purificada por passagem em sistema de osmose reversa. Esse sistema, apesar de apresentar maiores custos de implantação e sua operação exigir maiores controles e automatização, foi implantado nesta fábrica, onde os produtos cosméticos produzidos são mais sensíveis a contaminantes, exigindo maior confiabilidade e qualidade da água empregada.

O processo de produção de água purificada por osmose reversa está representado pelo diagrama da figura 6.9, e pelas fotos das figuras 6.10, 6.11, 6.12 e 6.13, consistindo das seguintes etapas:

a) A água potável que vem do reservatório vertical, passa inicialmente por um pré-tratamento consistindo de:

- desinfecção com a adição de hipoclorito de sódio;

- passagem por filtro de areia e antracito;

- passagem por um sistema abrandador (colunas de resina catiônica); 
- passagem por um sistema de dosagem de solução redutora de cloro (bissulfito de sódio), para eliminar o cloro residual que pode causar danos às membranas de osmose reversa;

- passagem por um sistema de controle de $\mathrm{pH}$ com adição de solução de $\mathrm{NaOH}$;

- passagem por um sistema de microfiltração em cartucho de $05 \mu \mathrm{m}$;

- passagem por uma etapa final de desinfecção por radiação UV (254 $\mathrm{nm})$.

b) A água segue então para o sistema de osmose reversa com capacidade de produção de $1.500 \mathrm{~L} / \mathrm{h}$, composto de duas etapas de membranas espirais de poliamida da Hydranautics, montadas pela empresa IPA da Argentina.

Da mesma forma que a etapa final do sistema de purificação por resina de troca iônica, a água purificada (permeada) é armazenada em reservatório e recircula deste por um sistema de desinfecção por UV (254 nm). Parte da corrente de água que sai do sistema de UV segue para a fabricação de cosméticos. O padrão estabelecido para essa água purificada é de no máximo $1,3 \mu \mathrm{S} / \mathrm{cm}$ a $20^{\circ} \mathrm{C}$, atendendo a U.S. Pharmacopeia, padrão normalmente utilizado uma vez que não existe legislação e normas com padrões de qualidade específicos para água utilizada na fabricação de cosméticos.

O fluxo de água de rejeito do sistema de osmose reversa, corrente de água com maior concentração de sais, que ainda assim possui características dentro do padrão de potabilidade da Portaria 518/2004, é reintroduzido no ponto de captação do poço artesiano, sendo incorporada à água que sai deste e recebe o tratamento de filtração e desinfecção na ETA.

Apesar da introdução dessa água ao sistema de captação, o aumento da concentração de sais verificado atinge um ponto de equilíbrio que mantém a água resultante dessa mistura dentro dos padrões de potabilidade. Esse equilíbrio deve se ao fato de que a relação entre a vazão do fluxo de rejeito reutilizado e a vazão do poço é pequena, sendo esta contribuição de cerca de 9,6 \% da vazão total da água 
produzida na ETA. Ou seja cerca de $35 \mathrm{~m}^{3} /$ dia de água de rejeito da operação da osmose reversa acrescentados aos cerca de $330 \mathrm{~m}^{3} /$ dia extraídos do poço, totalizando $365 \mathrm{~m}^{3} /$ dia. Essa alteração na concentração de sais, medida em termos de condutividade, está mostrada na tabela 6.2.

Tabela 6.2 - Condutividade no processo de mistura de água de rejeito da OR e água extraída do poço artesiano

\begin{tabular}{lc}
\hline \multicolumn{1}{c}{ Água } & $\begin{array}{c}\text { Condutividade } \\
(\mu \mathrm{S} / \mathbf{c m ~ a ~ 2 0} \mathrm{C})\end{array}$ \\
\hline Água de rejeito da OR & 795 \\
\hline Água do poço artesiano & 180 \\
\hline Água produzida na ETA & 230 \\
\hline
\end{tabular}

Fonte: (Relatórios internos da empresa de análises de águas)

Essa aplicação de reuso de água de rejeito de sistema de membranas de osmose reversa encontra respaldo em estudo realizado por You et al (2001), para indústria de semicondutores em Taiwan. 


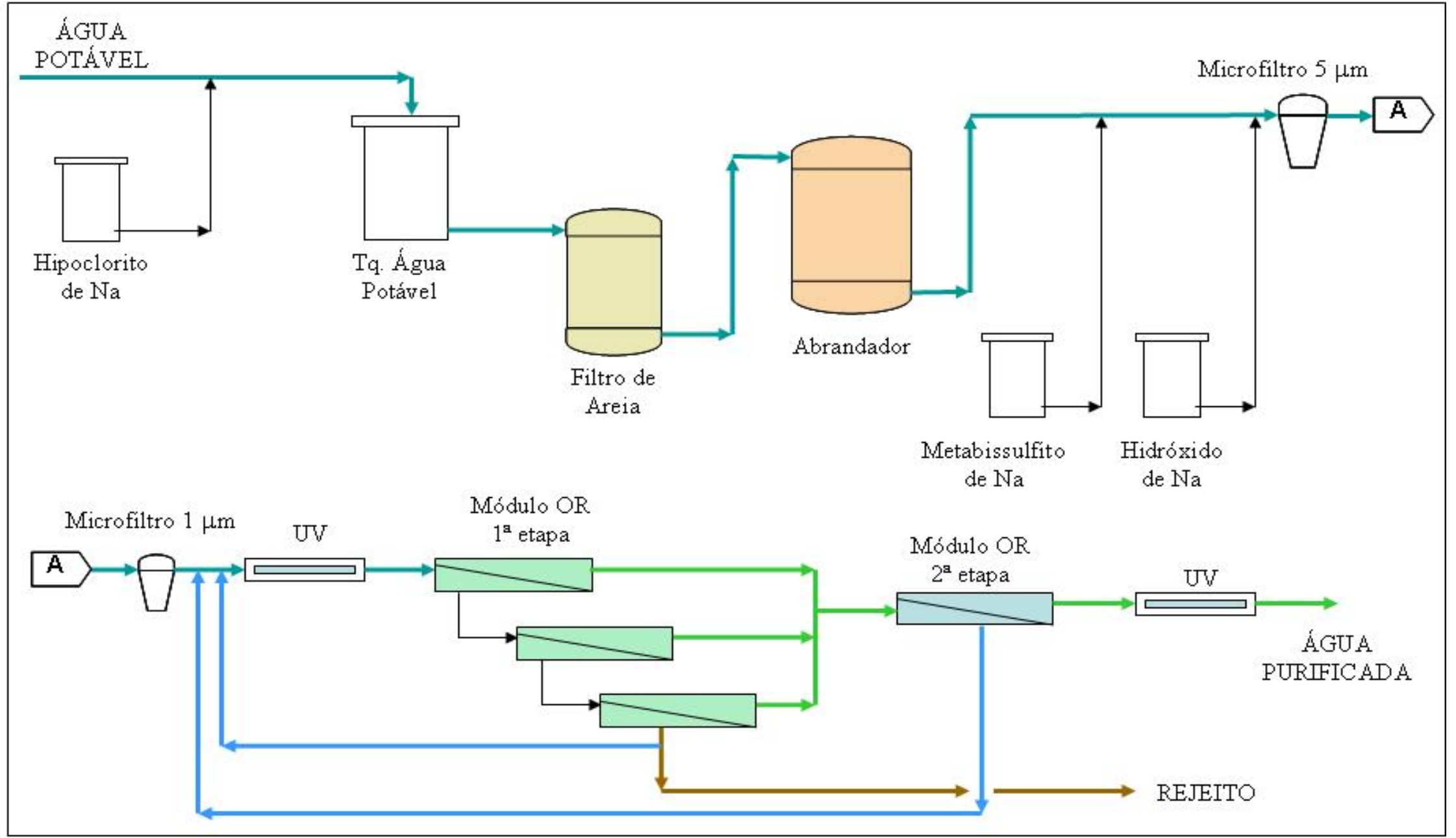

Figura 6.9 - Diagrama simplificado do sistema de osmose reversa (elaborado pelo autor) 


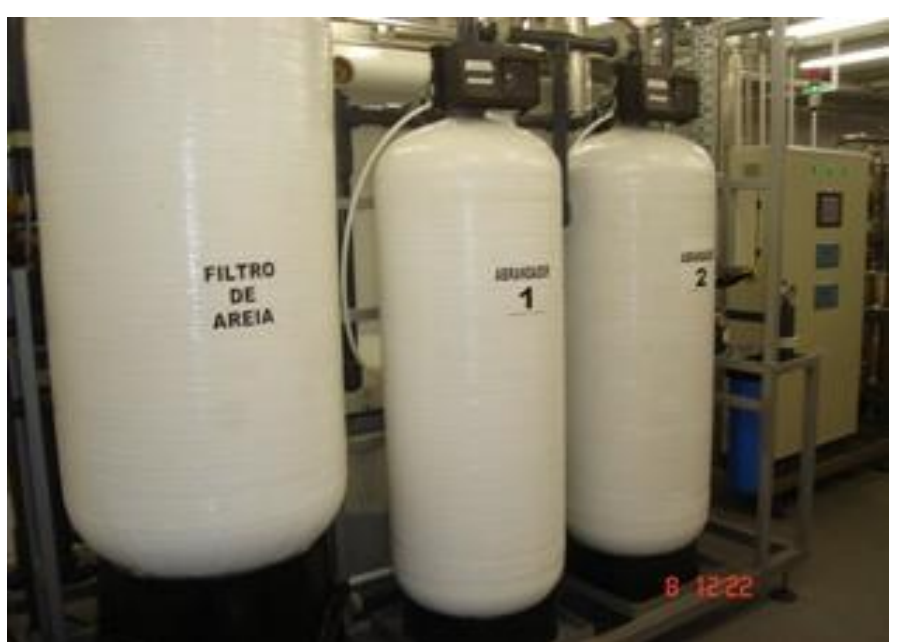

Figura 6.10 - Filtros e abrandadores

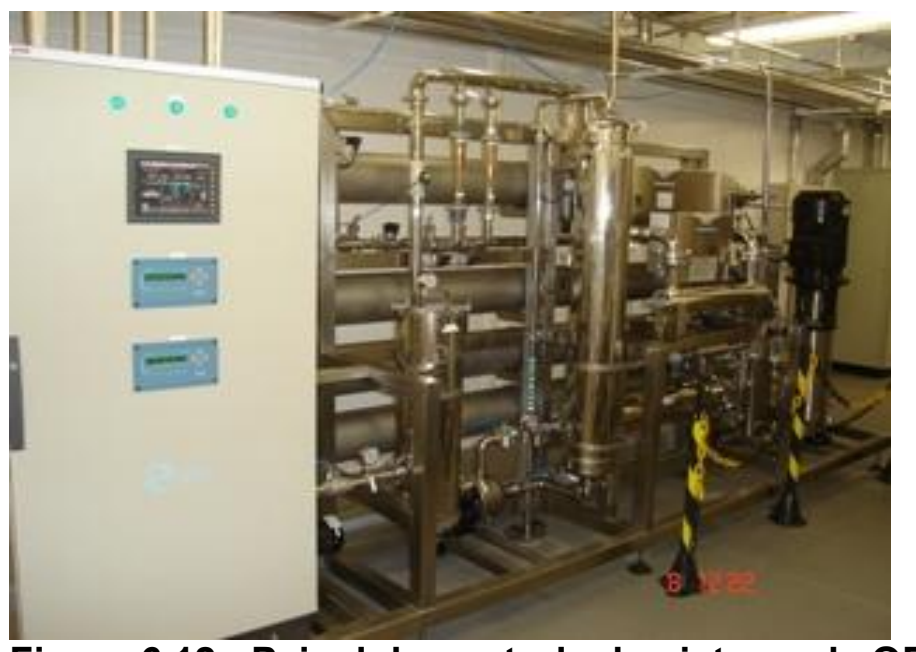

Figura 6.12 - Painel de controle do sistema de OR

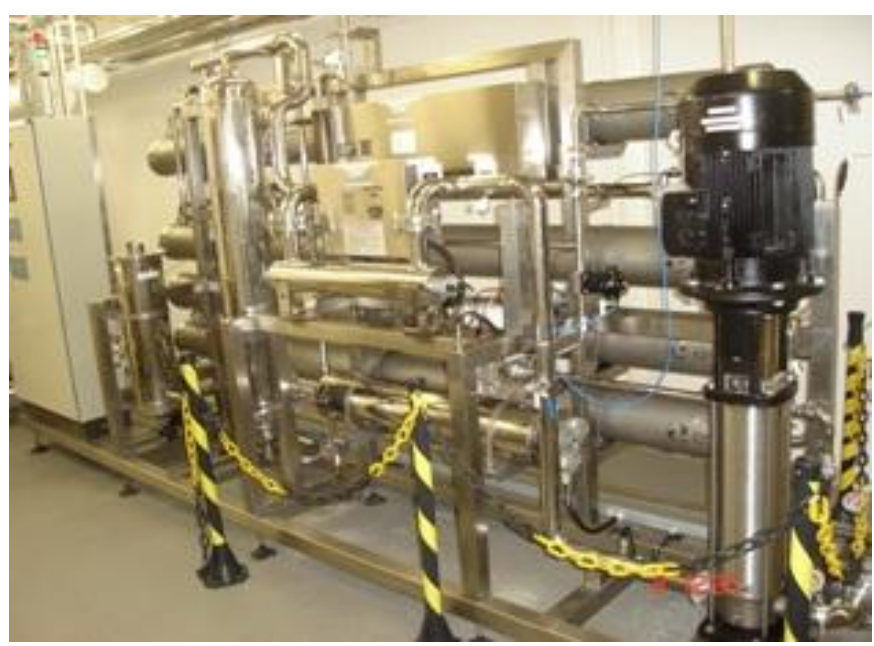

Figura 6.11 - Módulos de membranas de OR

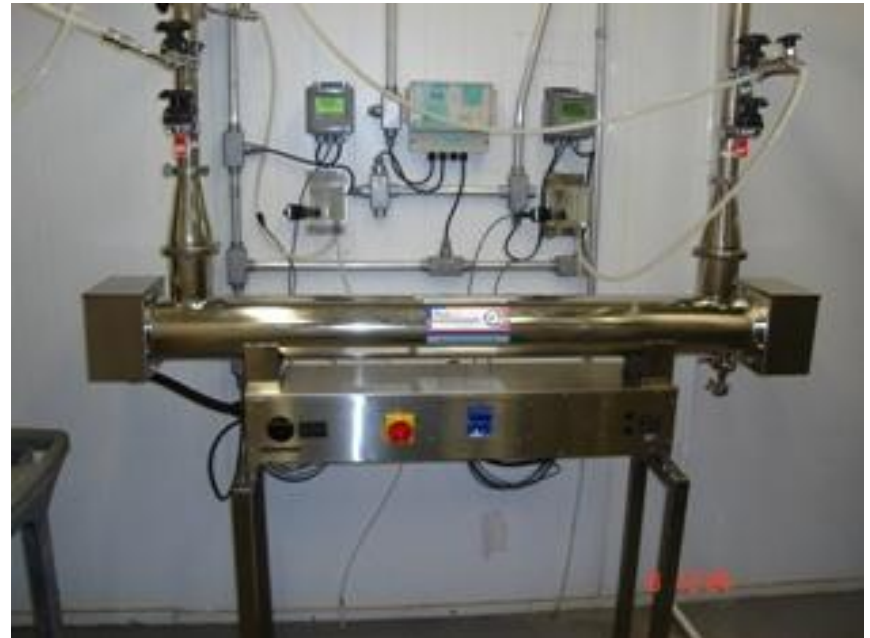

Figura 6.13 - Desinfecção por radiação UV 


\subsection{Sistema de tratamento de efluentes}

Para tratar os efluentes gerados pelo processo produtivo e o efluente sanitário, a empresa optou por uma estação de tratamento de efluentes que utiliza uma associação de processo físico-químico e tratamento biológico aeróbio, seguido por sistema que utiliza membranas de ultrafiltração, por onde parte do substrato do reator biológico circula, removendo assim o excedente de lodo para posterior condicionamento e filtração. Esse arranjo proporciona uma elevada eficiência na remoção da carga orgânica em termos de DBO, bem como elimina a necessidade de um decantador após o reator aeróbio, ocupando também uma área relativamente pequena. A figura 6.14 mostra um fluxograma básico do processo.

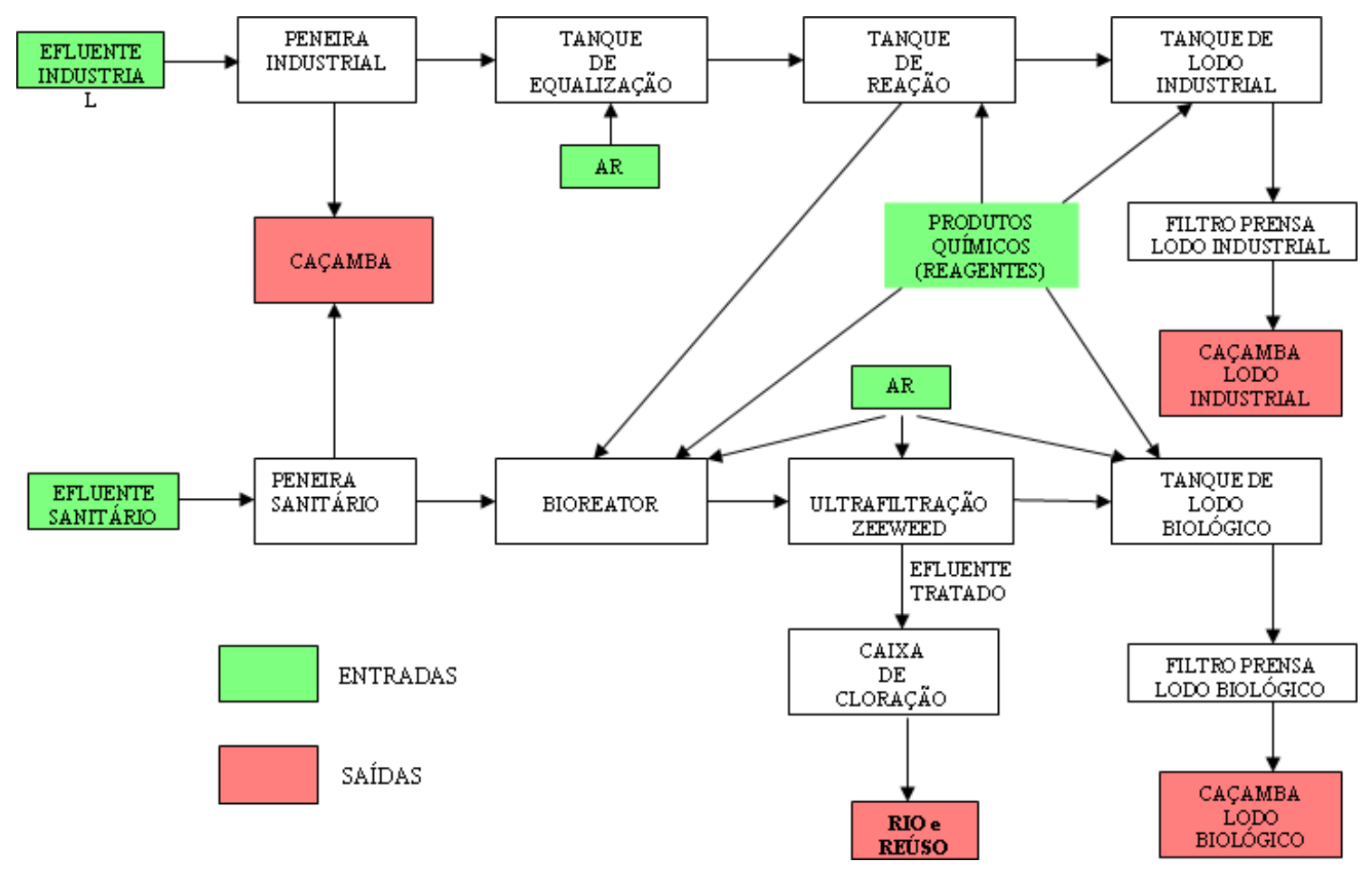

Figura 6.14 - Fluxograma básico do sistema de tratamento de efluentes

Com esse processo obtêm-se efluente tratado com mais de $99 \%$ de remoção de DBO e que permite o reúso do mesmo em aplicações com menores exigências tais como o uso em descarga de vasos sanitários e mictórios, rede de combate a incêndio, lavagem de ruas e edificações e aplicação em jardinagem. Tem-se a 
geração de cerca de $300 \mathrm{~m}^{3} /$ dia de efluente tratado, sendo que apenas Segundo estudo de Hoinkis e Pantem (2008), é possível ainda a utilização desse efluente para fins mais nobres com a aplicação de um tratamento terciário, tal como osmose reversa, de forma a se obter água de melhor qualidade que atenda a processos mais exigentes quanto a qualidade.

O tratamento biológico atualmente empregado consiste de dois reatores de lodos ativados em paralelo, com forte aeração (reator de mistura completa) que, além de garantir o suprimento de $\mathrm{O}_{2}$ à massa biológica, a mantém em suspensão e misturada em todo o reator.

O sistema de ultrafiltração foi desenvolvido pela empresa canadense Zeweed Zenon, atualmente pertencente ao conglomerado GE, figura 6.15 e 6.16 .

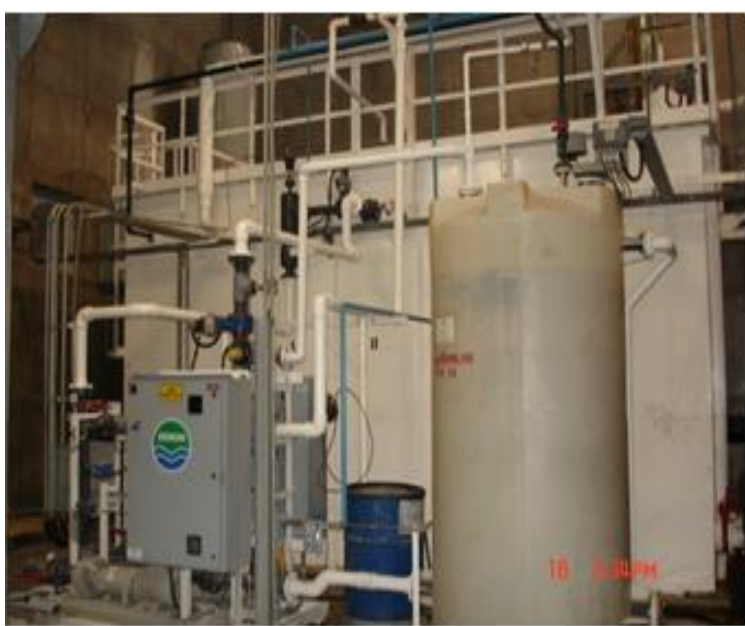

Figura 6.15 - Sistema de ultrafiltração

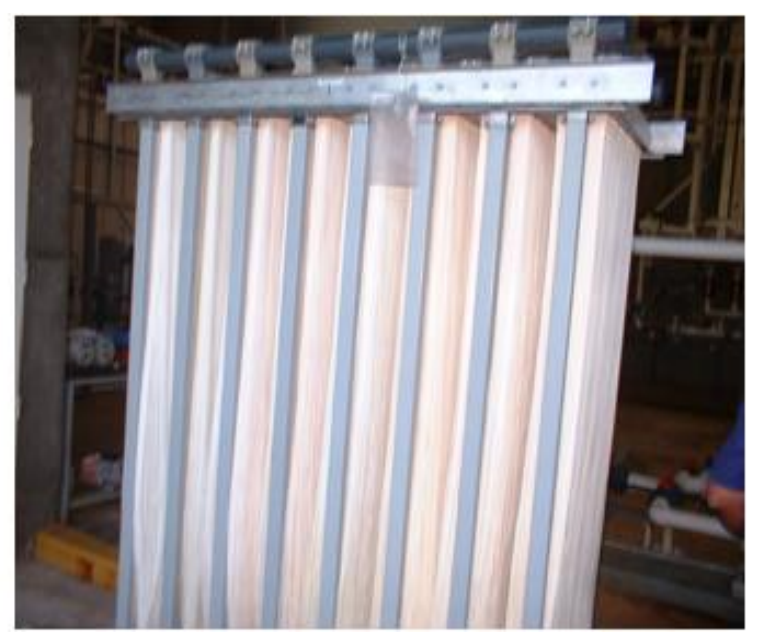

Figura 6.16 - Cassete de membranas de ultrafiltração

\section{Efluentes domésticos e sanitários}

Os efluentes sanitários contêm grande concentração de matéria orgânica, provenientes das águas usadas no restaurante, pias e vasos sanitários nos banheiros. Assim os resultados de uma análise pontual realizada pela empresa de consultoria ambiental Ecolabor em 11/02/2009 apresentou os seguintes valores na caracterização desse efluente antes de seu tratamento: 
Tabela 6.3 - Resultados de análise de efluente sanitário

\begin{tabular}{|c|c|c|c|}
\hline Parâmetros & Unidades & $\begin{array}{c}\text { Padrão art. } 18 \\
\text { do Dec. } \\
8.468 / 76\end{array}$ & Resultado \\
\hline $\mathrm{pH}$ & $\mathrm{pH}$ & $5,0-9,0$ & 6,6 \\
\hline Temperatura de campo & ${ }^{\circ} \mathrm{C}$ & $<40$ & 25 \\
\hline Resíduo Sedimentável & $\mathrm{ml} / \mathrm{L}$ & 1,0 & 18 \\
\hline D.B.O. 5 & $\mathrm{mg} \mathrm{O}_{2} / \mathrm{L}$ & 60 & $1,14 \times 10^{3}$ \\
\hline D.Q.O. & $\mathrm{mg} \mathrm{O}_{2} / \mathrm{L}$ & 7 & $2,0 \times 10^{3}$ \\
\hline Óleo e Graxas & $\mathrm{mg} / \mathrm{L}$ & 3 & 230 \\
\hline Arsênio & $\mathrm{mg} / \mathrm{L}$ & 0,2 & n.d. \\
\hline Bário & $\mathrm{mg} / \mathrm{L}$ & 5,0 & 0,035 \\
\hline Boro & $\mathrm{mg} / \mathrm{L}$ & 5,0 & 0,15 \\
\hline Cádmio & $\mathrm{mg} / \mathrm{L}$ & 0,2 & n.d. \\
\hline Chumbo & $\mathrm{mg} / \mathrm{L}$ & 0,5 & 0,12 \\
\hline Cianeto & $\mathrm{mg} / \mathrm{L}$ & 0,2 & n.d. \\
\hline Cobre & $\mathrm{mg} / \mathrm{L}$ & 1,0 & 0,082 \\
\hline Cromo Hexavalente & $\mathrm{mg} / \mathrm{L}$ & 0,1 & n.d. \\
\hline Cromo Total & $\mathrm{mg} / \mathrm{L}$ & 5,0 & 0,068 \\
\hline Estanho & $\mathrm{mg} / \mathrm{L}$ & 4,0 & n.d. \\
\hline Fenol & $\mathrm{mg} / \mathrm{L}$ & 0,5 & 0,11 \\
\hline Ferro Solúvel & $\mathrm{mg} / \mathrm{L}$ & 15,0 & 1,02 \\
\hline Fluoreto & $\mathrm{mg} / \mathrm{L}$ & 10,0 & 6,6 \\
\hline Manganês Solúvel & $\mathrm{mg} / \mathrm{L}$ & 1,0 & 0,099 \\
\hline Mercúrio & $\mathrm{mg} / \mathrm{L}$ & 0,01 & n.d. \\
\hline Níquel & $\mathrm{mg} / \mathrm{L}$ & 2,0 & 0,027 \\
\hline Prata & $\mathrm{mg} / \mathrm{L}$ & 0,02 & n.d. \\
\hline Selênio & $\mathrm{mg} / \mathrm{L}$ & 0,02 & n.d. \\
\hline Zinco & $\mathrm{mg} / \mathrm{L}$ & 5,0 & 0,56 \\
\hline
\end{tabular}

Fonte: (Relatório Ecolabor de análise de efluentes sanitários - 11/02/2009)

A coleta dos efluentes sanitários é realizada através do sistema EVAC, da empresa suéca Evac Vacuum Systems, que utiliza vácuo para succionar e transportar os resíduos domésticos até a ETE, propiciando uma redução de até $80 \%$ no volume de efluente sanitário gerado em relação ao sistema convencional por gravidade, promovendo também uma homogeinização destes e maior concentração da carga a ser tratada (Figura 6.17). 


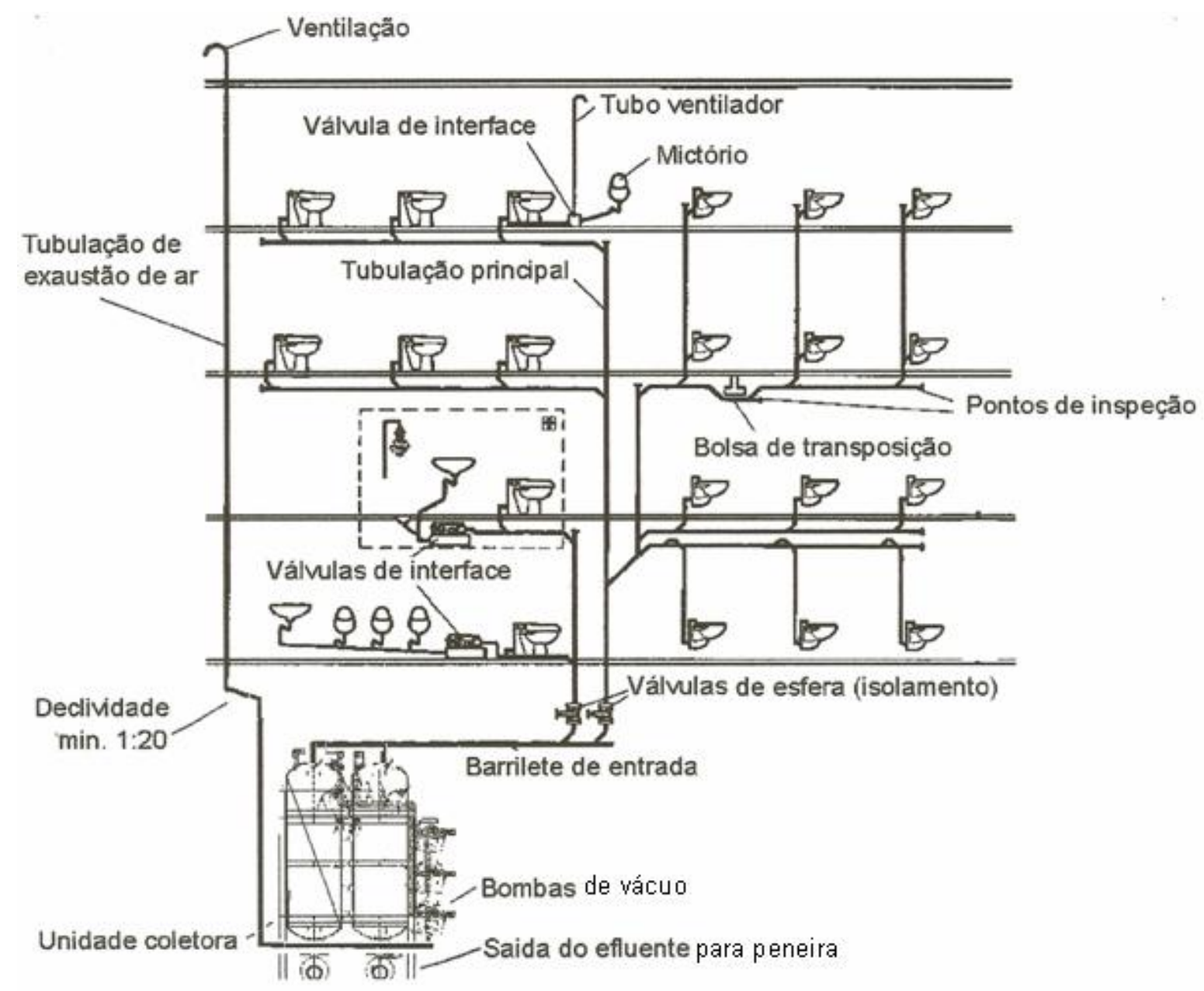

Figura 6.17 - Sistema de captação de esgotos sanitários a vácuo Fonte: Manual de operação do sistema EVAC

Esses efluentes sanitários, provenientes de bacias sanitárias a vácuo consomem 1,2 $\mathrm{L} /$ descarga, enquanto bacias convencionais acopladas que utilizam descargas por gravidade consomem 6 L/descarga. Esses efluentes não recebem nenhum outro tratamento, sendo enviados ao biorreator passando antes pelas seguintes etapas:

1) Peneira para sólidos grosseiros - onde são retirados elementos sólidos como metais, plásticos, tecidos e demais partículas sólidas. São retirados em caçambas e destinados a aterros sanitários controlados;

2) Elevatória 2 ou tanque de equalização 2 (sanitário) - tanque de $7 \mathrm{~m}^{3}$ que tem a função de controlar e regularizar a vazão para a etapa posterior no biorreator. 


\section{Efluentes industriais}

Os efluentes industriais possuem elevada carga de materiais orgânicos e inorgânicos, devido às diferentes matérias primas componentes dos cosméticos, especialmente óleos e graxas, álcool, essências, pigmentos corantes. Esses são provenientes das lavagens de tanques e equipamentos, lavagens de pisos industriais, eventuais derramamentos e descartes. Assim um tratamento preliminar físico-químico é aplicado com o uso de sulfato de alumínio e polieletrólitos visando flocular e sedimentar a carga poluente, adequando-a para que seja utilizada no biorreator.

A utilização de sulfato de alumínio é preferível ao cloreto férrico anteriormente utilizado nesta ETE por melhorar as características do efluente final tratado, ou seja, diminuir o teor de cloretos e cor, além do menor custo do reagente. Os resultados de uma análise pontual realizada pela empresa de consultoria ambiental Ecolabor em 11/02/2009 apresentou os seguintes valores na caracterização desse efluente antes de seu tratamento:

Tabela 6.4 - Resultados de análise de efluente industrial

\begin{tabular}{lccc}
\hline \multicolumn{1}{c}{ Parâmetros } & Unidades & $\begin{array}{c}\text { Padrão art. 18 } \\
\text { do Dec. } \\
\mathbf{8 . 4 6 8 / 7 6}\end{array}$ & Resultado \\
\hline $\mathrm{pH}$ & $\mathrm{pH}$ & $5,0-9,0$ & $\mathbf{7 , 1}$ \\
\hline Temperatura de campo & ${ }^{\circ} \mathrm{C}$ & $<40$ & $\mathbf{2 5}$ \\
\hline Resíduo Sedimentável & $\mathrm{ml} / \mathrm{L}$ & 1,0 & $\mathbf{4 0}$ \\
\hline D.B.O. 5 & $\mathrm{mg} \mathrm{O}_{2} / \mathrm{L}$ & 60 & $\mathbf{4 , 2} \times \mathbf{1 0}^{3}$ \\
\hline D.Q.O. & $\mathrm{mg} \mathrm{O} / \mathrm{L}$ & 7 & $\mathbf{9 , 7} \mathbf{1 0} \mathbf{1 0}^{3}$ \\
\hline Óleo e Graxas & $\mathrm{mg} / \mathrm{L}$ & 3 & $\mathbf{5 0 7}$ \\
\hline Arsênio & $\mathrm{mg} / \mathrm{L}$ & 0,2 & $\mathbf{n . d}$ \\
\hline Bário & $\mathrm{mg} / \mathrm{L}$ & 5,0 & $\mathbf{0 , 0 4 2}$ \\
\hline Boro & $\mathrm{mg} / \mathrm{L}$ & 5,0 & $\mathbf{0 , 5 3}$ \\
\hline Cádmio & $\mathrm{mg} / \mathrm{L}$ & 0,2 & $\mathbf{n . d .}$ \\
\hline Chumbo & $\mathrm{mg} / \mathrm{L}$ & 0,5 & $\mathbf{0 , 0 0 9}$ \\
\hline Cianeto & $\mathrm{mg} / \mathrm{L}$ & 0,2 & $\mathbf{0 , 0 0 5}$ \\
\hline Cobre & $\mathrm{mg} / \mathrm{L}$ & 1,0 & $\mathbf{0 , 0 5 5}$ \\
\hline Cromo Hexavalente & $\mathrm{mg} / \mathrm{L}$ & 0,1 & n.d. \\
\hline Cromo Total & $\mathrm{mg} / \mathrm{L}$ & 5,0 & $\mathbf{0 , 0 7 0}$ \\
\hline Estanho & $\mathrm{mg} / \mathrm{L}$ & 4,0 & n.d. \\
\hline Fenol & $\mathrm{mg} / \mathrm{L}$ & 0,5 & $\mathbf{1 1 , 7 1}$ \\
\hline Ferro Solúvel & $\mathrm{mg} / \mathrm{L}$ & 15,0 & $\mathbf{1 , 8 5}$ \\
\hline
\end{tabular}


Tabela 6.4 - Resultados de análise de efluente industrial (continuação)

\begin{tabular}{lccc}
\hline Parâmetros & Unidades & $\begin{array}{c}\text { Padrão art. 18 } \\
\text { do Dec. } \\
\mathbf{8 . 4 6 8 / 7 6}\end{array}$ & Resultado \\
\hline Fluoreto & $\mathrm{mg} / \mathrm{L}$ & 10,0 & $\mathbf{2 2}$ \\
\hline Manganês Solúvel & $\mathrm{mg} / \mathrm{L}$ & 1,0 & $\mathbf{0 , 0 4 9}$ \\
\hline Mercúrio & $\mathrm{mg} / \mathrm{L}$ & 0,01 & $\mathbf{n . d .}$ \\
\hline Níquel & $\mathrm{mg} / \mathrm{L}$ & 2,0 & $\mathbf{0 , 0 2 9 8}$ \\
\hline Prata & $\mathrm{mg} / \mathrm{L}$ & 0,02 & $\mathbf{n . d .}$ \\
\hline Selênio & $\mathrm{mg} / \mathrm{L}$ & 0,02 & $\mathbf{n . d .}$ \\
\hline Zinco & $\mathrm{mg} / \mathrm{L}$ & 5,0 & $\mathbf{0 , 7 0 1}$ \\
\hline
\end{tabular}

Fonte: (Relatório Ecolabor de análise de efluentes industriais - 11/02/2009)

\section{Tratamento físico-químico}

A etapa de tratamento físico-químico para os efluentes industriais compõe-se de:

1) Peneira para sólidos grosseiros - onde são retirados elementos sólidos como lacres, plásticos, tampas, etc. São retirados em caçambas e destinados a aterros sanitários controlados;

2) Tanque pulmão (saída das fábricas) - tanque de $20 \mathrm{~m}^{3}$ que tem a função de controlar e regularizar a vazão às etapas posteriores;

3) Tanque de equalização de $3 \mathrm{~m}^{3}$ - tem a função de homogeneizar a massa líquida e seus componentes através da injeção de ar;

4) Tanque de reação (tanque de coagulação) - com capacidade de $50 \mathrm{~m}^{3}$ e agitação mecânica, é onde é feita a adição de $\mathrm{Al}_{2}\left(\mathrm{SO}_{4}\right)_{3}$, em solução a 50\%, o que faz o pH cair a 3,5 - 4,0. Adiciona-se então solução de $\mathrm{NaOH}$ que eleva o pH a 6,5 - 7,9. Adiciona-se polieletrólito aniônico e logo após cessa-se a agitação para que se formem os flocos que sedimentam (Figura 6.18);

5) Envio do sobrenadante do tanque de reação a um tanque intermediário (Elevatória 1), que tem a função de segurança e controle de vazão, regularizando o fluxo ao biorreator aeróbico; 
6) Elevatória 1 - conjunto de tanque e bomba que envia o sobrenadante do tanque de reação ao biorreator aeróbico de forma contínua e regular;

7) Envio do lodo decantado ao fundo do tanque de reação para o tanque de lodo industrial;

8) Tanque de lodo industrial - com $45 \mathrm{~m}^{3}$, onde recebe cal hidratada e tem $0 \mathrm{pH}$ ajustado em torno de 8,5. Deste tanque, que acumula lodo decantado proveniente de até 4 bateladas do tanque de reação, o material é enviado ao filtro-prensa de "lodo físico-químico";

9) Filtro-prensa de lodo físico-químico, figura 6.19;

10)Envio do líquido extraído do filtro-prensa para o tanque de equalização;

11) Envio da torta de filtragem (torta de lodo industrial) para caçamba que tem como destino empresa especializada para uso em processo de compostagem. Essa torta possui cerca de $75 \%$ de umidade;

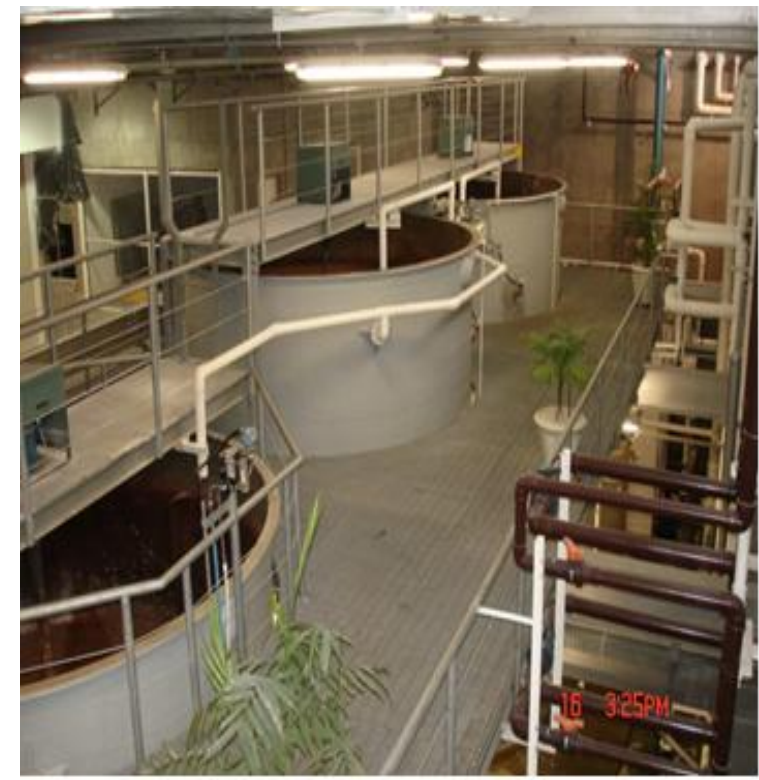

Figura 6.18 - Tanques de tratamento físico-químico

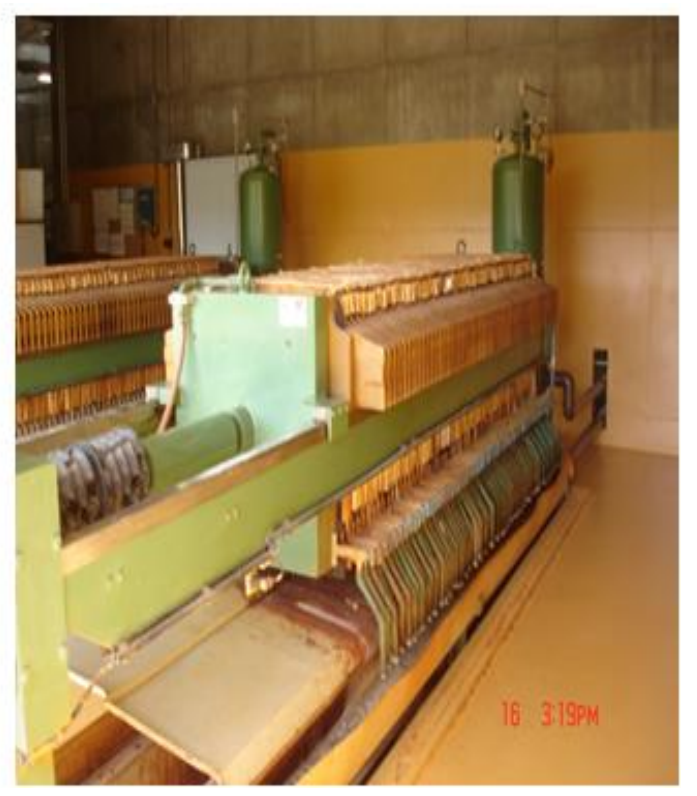

Figura 6.19 -Filtros-prensas 


\section{Biorreator aeróbio por lodo ativado}

Os efluentes sanitários e o sobrenadante do pré-tratamento do efluente industrial são levados ao biorreator aeróbio onde a matéria orgânica é digerida pela massa de microorganismos. Essa massa biológica é mantida continuamente em equilíbrio pela injeção de nutrientes presentes nos efluentes, pela adição de micro-nutrientes essenciais ao crescimento biológico e pela introdução de ar ou $\mathrm{O}_{2}$ puro. Também é controlada a condição ideal de temperatura. A agitação contínua do meio é garantida pela própria introdução de ar ou $\mathrm{O}_{2}$.

Esse reator biológico é dividido em duas secções de $1.000 \mathrm{~m}^{3}$ cada (biorreator $\mathrm{A} \mathrm{e}$ biorreator B), mas que trabalham interligados e com as seguintes condições:

a) Massa biológica - proveniente de cepas fornecidas pela Sabesp;

b) Temperatura de operação $-37^{\circ} \mathrm{C}$;

c) $\mathrm{pH}$ no substrato - 6,5 a 7,9;

d) Altura da massa líquida - 9 m;

e) Sistema de aeração - atualmente $\mathrm{O}_{2}$ puro, fornecido pela empresa White Martins, através de dispersores rotativos no fundo do tanque;

f) Concentração de $\mathrm{O}_{2}-1$ a $2 \mathrm{mg}$ de $\mathrm{O}_{2} / \mathrm{L}$;

g) Concentração de sólidos - entre 15 a 20 g/L;

h) Tempo de residência - 4 dias.

Anteriormente o sistema de aeração consistia de sopradores de alta vazão, que insuflavam 0 ar através de tubos de distribuição e crepinas. Esse sistema não permitia concentrações de $\mathrm{O}_{2}$ maiores que $0,6 \mathrm{mg}$ de $\mathrm{O}_{2} / \mathrm{L}$.

O sistema de injeção de $\mathrm{O}_{2}$ puro atualmente empregado trouxe como vantagem, a eliminação do custo de manutenção dos sopradores de ar, menor custo de energia, eliminação do ruído gerado por estes sopradores, maior concentração de $\mathrm{O}_{2}$ 
dissolvido no substrato, melhor controle da concentração de $\mathrm{O}_{2}$ e diminuição do tempo de residência de 5 a 6 dias para 4 dias. Com isso obteve-se maior flexibilidade para atendimento a aumentos de demanda, sem a necessidade de ampliação de instalações.

\section{Sistema de ultrafiltração ZeeWeed-Zenon}

Do reator biológico parte do substrato é recirculado através do sistema de ultrafiltração ZeeWeed-Zenon (Figuras 6.15 e 6.16), que utiliza membranas capilares de polissulfona, com porosidade de 0,4 $\mathrm{mm}$, diâmetro interno de 0,9 mm e externo de $1,9 \mathrm{~mm}$, montadas em cassetes. A taxa de recirculação é tal que sua vazão é 5 vezes maior que a vazão de permeado (efluente tratado) produzido.

O fluxo entre o biorreator e o sistema de ultrafiltração é representado pela figura 6.20 .

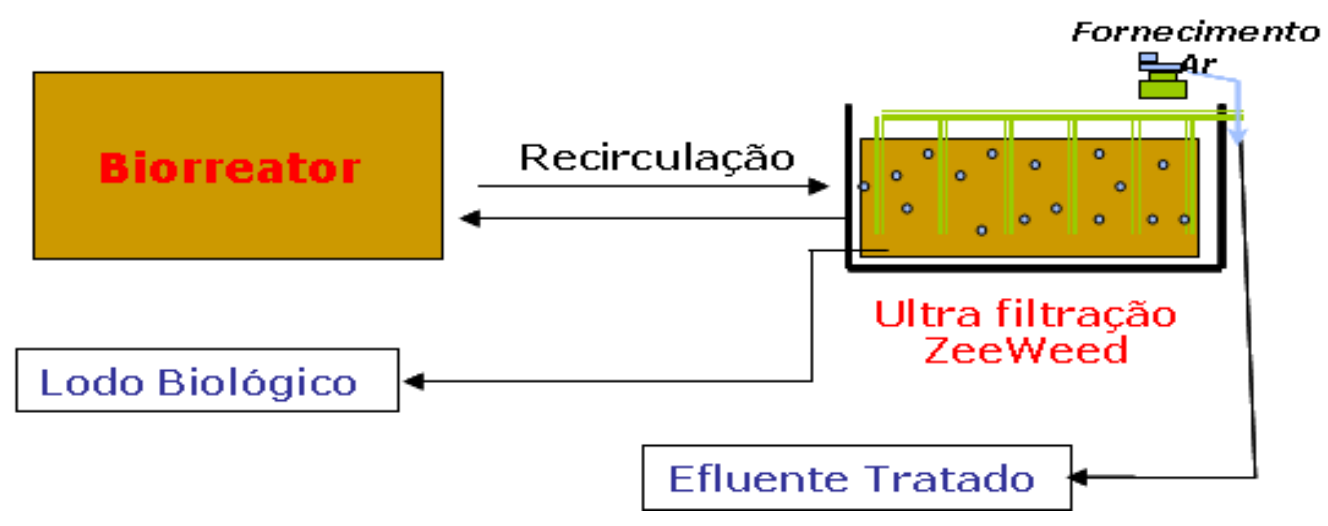

Figura 6.20 - Diagrama da recirculação de substrato entre o biorreator e o sistema de ultrafiltração (elaborado pelo autor)

A seqüência das operações para o tratamento final de efluentes é:

1) A água permeada através das membranas é enviada para o reservatório de efluente tratado sendo antes clorada em linha com solução de hipoclorito de sódio, mantendo um teor de cloro de 1,5 a 2 ppm; 
2) $\mathrm{Na}$ contra lavagem das membranas, a cada $15 \mathrm{~min}$ e durante $30 \mathrm{seg}, \mathrm{o}$ lodo é enviado para o tanque de lodo biológico. Esse lodo possui um teor de STD de 15 a $20 \mathrm{mg} / \mathrm{L}$;

3) Filtração do lodo biológico - do tanque de lodo biológico este é enviado ao filtro-prensa onde se obtém a torta de filtração com teor de umidade de $75 \%$;

4) Retorno dos líquidos - do tanque de lodo biológico e do filtro-prensa, esses líquidos são retornados ao reator biológico;

5) Envio da torta de filtragem do tratamento biológico para uso em compostagem, por empresa especializada.

A capacidade de tratamento da ETE é de $340 \mathrm{~m}^{3} / \mathrm{dia}$. Considerando-se as características do efluente (resíduos químicos e esgotos sanitários) e seu volume, isso equivale ao que seria gerado por uma cidade de 65 mil habitantes. A figura 6.21 mostra todas as etapas do processo de tratamento de efluentes.

Esse processo permite que a água tratada possa ser utilizada para rega de jardins, rede de combate a incêndio, sanitários (bacias e mictórios), lavagem de ruas, etc. (Tabela 6.3).

O efluente tratado final atende as exigências mais restritas do Decreto Estadual $n^{\circ}$ 8468 (art. 12 e 18) e Resolução CONAMA n 357 (art. 34), sendo que a empresa possui outorga que the concede o lançamento superficial de efluentes tratados de até $15 \mathrm{~m}^{3} / \mathrm{h}$. Considerando que cerca de $45 \%$ do efluente tratado gerado não é utilizado, são lançados ao Rio Juquery $110 \mathrm{~m}^{3} /$ dia desse efluente, o que constitui uma oportunidade importante para aplicação em programas de reúso.

Para o Decreto Estadual n 8.468 de 1976, o artigo 12 define o padrão que não deve ser alterado em coleções de água Classe 2, como é o caso do Rio Juquery, pelo lançamento de efluentes mesmo que tratados.

O artigo 18 define o padrão de lançamento dos efluentes, mesmo que tratados, nas coleções de água. 
O artigo 19A não se aplica uma vez que é o padrão de lançamento dos efluentes diretamente na rede de esgotamento pública, desde que possua tratamento adequado. Esse padrão é menos restritivo que o artigo 12. 


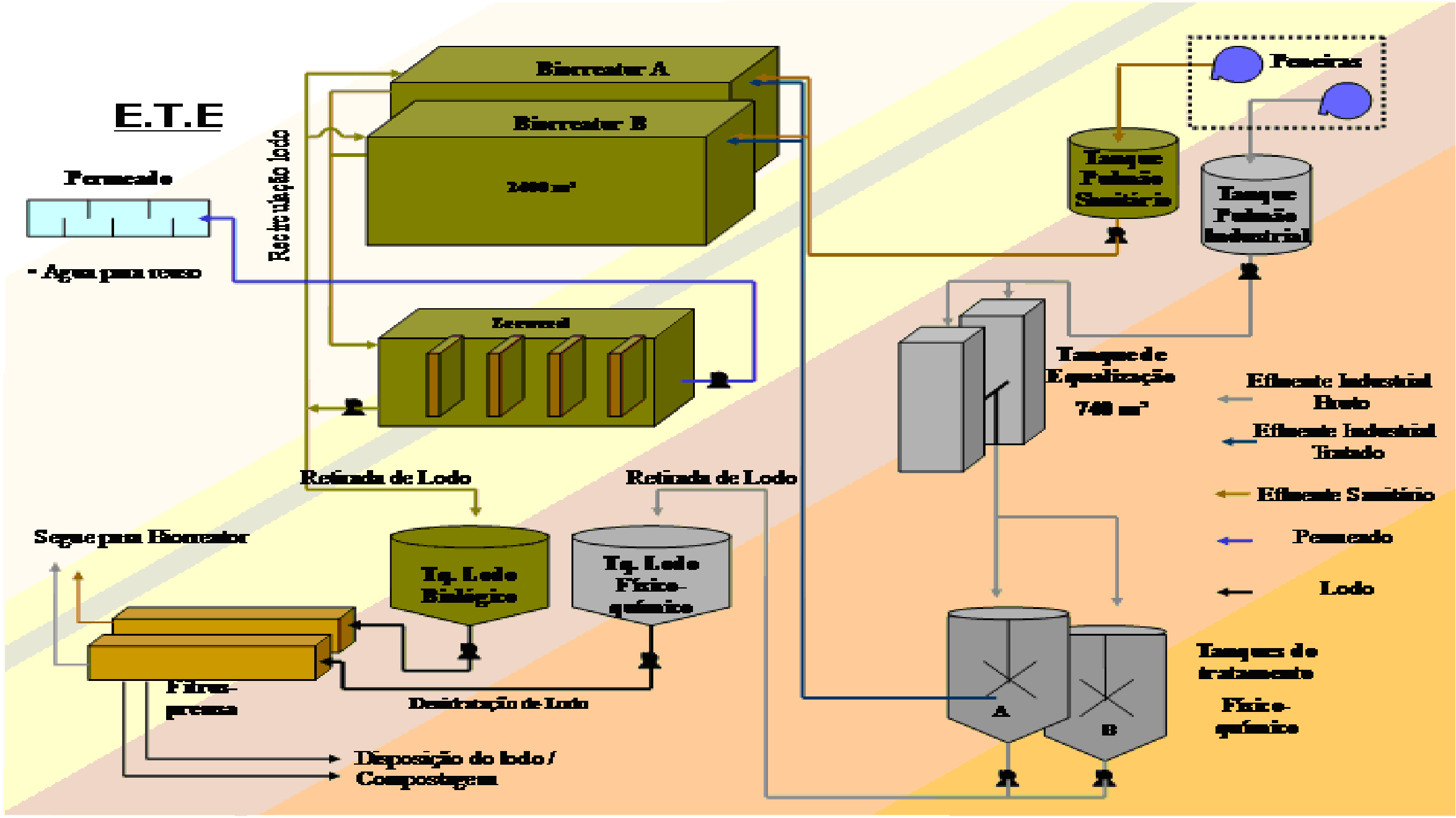

Figura 6.21 - Diagrama da Estação de Tratamento de Efluentes 


\subsubsection{Características do efluente sanitário}

Alguns parâmetros básicos desse efluente apresentam os seguintes valores médios:

- $\quad \mathrm{DBO}-890 \mathrm{mg} / \mathrm{L}$

- $\mathrm{DQO}-1.827 \mathrm{mg} / \mathrm{L}$

- $\mathrm{O} \& \mathrm{G}-39,4 \mathrm{mg} / \mathrm{L}$

- $\mathrm{pH}-6,6$

Esse efluente, juntamente com o efluente industrial que sai do pré-tratamento com sulfato de alumínio, alimenta o biorreator aeróbio.

\subsubsection{Características do efluente industrial}

Os efluentes industriais da empresa têm como característica a elevada concentração de substâncias inorgânicas, além de quantidades de resíduos oleosos e alcoólicos.

Outra característica é a grande variabilidade da carga poluente e, especialmente de seu volume, que dependem da sazonalidade típica das vendas de produtos cosméticos. Os valores médios para alguns parâmetros básicos desse efluente são:

- $\quad$ DBO - $7.560 \mathrm{mg} / \mathrm{L}$

- $\mathrm{DQO}-15.268 \mathrm{mg} / \mathrm{L}$

- $\mathrm{O} \& \mathrm{G}-278 \mathrm{mg} / \mathrm{L}$

- $\mathrm{pH}-8,9$ 


\subsubsection{Características do efluente final tratado (ou permeado)}

Após a ultrafiltração o efluente final tratado ou permeado, que é armazenado em reservatório com $900 \mathrm{~m}^{3}$ para o sistema de combate a incêndio, tem seu excedente enviado ao Rio Juquery. Parte do permeado também é enviado para um dos compartimentos da caixa d'água vertical com capacidade de $200 \mathrm{~m}^{3}$ (Figura 6.11) e é, daí, enviado por gravidade para as outras aplicações de reúso tais como uso em banheiros, rede de aspersores para jardinagem, lavagem de ruas, lavagem de estruturas e paredes.

Assim, de todo o efluente tratado gerado (cerca de $8.500 \mathrm{~m}^{3} / \mathrm{mês}$ ) cerca de $55 \%$ é reutilizado, porém os outros $45 \%$ que são enviados ao Rio Juquery poderiam ser aproveitados também desde que suas características fossem melhoradas. Para isso, um processo de tratamento posterior deve ser utilizado, como passagem em membranas de osmose reversa (HOINKIS; PANTEN, 2006), ou até mesmo como sugerido por Sarkar com o uso de filtração prévia em carvão ativado para retirada de cor e odor, seguido depois por passagem em membranas de osmose reversa (SARKAR et al., 2006). Como essas possibilidades não puderam ser avaliadas neste trabalho recomenda-se que sejam consideradas em um próximo estudo.

Esse efluente final tratado possui os seguintes valores médios para os alguns de seus parâmetros básicos :

- $\mathrm{DBO}-5 \mathrm{mg} / \mathrm{l}$

- $\mathrm{DQO}-50 \mathrm{mg} / \mathrm{l}$

- $\mathrm{O} \& \mathrm{G}-2 \mathrm{mg} / \mathrm{l}$

- $\mathrm{pH}-7,4$

A tabela 6.5 mostra a caracterização desse efluente conforme resultados extraídos de laudo de análise realizada em 23 de setembro de 2008 pela empresa Nova Ambi Serviços Ambientais Ltda., contratada para avaliação semestral. Esse efluente 
tratado final é que é usado como água de reúso e seu excedente não utilizado é enviado ao Rio Juquery.

Tabela 6.5 - Resultados de análise de efluente tratado

\begin{tabular}{lccc}
\hline \multicolumn{1}{c}{ Parâmetros } & Unidades & $\begin{array}{c}\text { Padrão art. 34 } \\
\text { da CONAMA } \\
\mathbf{3 5 7 / 0 5}\end{array}$ & Resultado \\
\hline $\mathrm{pH}$ & $\mathrm{pH}$ & $5,0-9,0$ & $\mathbf{7 , 4}$ \\
\hline Temperatura de campo & ${ }^{\circ} \mathrm{C}$ & $<40$ & $\mathbf{3 2}$ \\
\hline Resíduo Sedimentável & $\mathrm{ml} / \mathrm{L}$ & 1,0 & $<\mathbf{0 , 1}$ \\
\hline D.B.O. Solúvel & $\mathrm{mg} \mathrm{O} / \mathrm{L}$ & 60 & $<\mathbf{2}$ \\
\hline Eficiência de Remoção DBO & $\%$ & $\mathrm{~min} 80 \%$ & $>\mathbf{9 9 , 8} \%$ \\
\hline D.Q.O & $\mathrm{mg} \mathrm{O} / \mathrm{L}$ & 150 & $<\mathbf{5}$ \\
\hline Óleos e graxas minerais & $\mathrm{mg} / \mathrm{L}$ & 20 & $\mathbf{4 , 1}$ \\
\hline Óleo e Graxas & $\mathrm{mg} / \mathrm{L}$ & 50 & $<\mathbf{1 0}$ \\
\hline Arsênio & $\mathrm{mg} / \mathrm{L}$ & 0,2 & $<\mathbf{0 , 0 1}$ \\
\hline Bário & $\mathrm{mg} / \mathrm{L}$ & 5,0 & $<\mathbf{0 , 1}$ \\
\hline Boro & $\mathrm{mg} / \mathrm{L}$ & 5,0 & $<\mathbf{0 , 0 1}$ \\
\hline Cádmio & $\mathrm{mg} / \mathrm{L}$ & 0,2 & $<\mathbf{0 , 0 1}$ \\
\hline Chumbo & $\mathrm{mg} / \mathrm{L}$ & 0,5 & $<\mathbf{0 , 1}$ \\
\hline Cianeto & $\mathrm{mg} / \mathrm{L}$ & 0,2 & $<\mathbf{0 , 0 1}$ \\
\hline Cobre & $\mathrm{mg} / \mathrm{L}$ & 1,0 & $<\mathbf{0 , 0 5}$ \\
\hline Cromo Hexavalente & $\mathrm{mg} / \mathrm{L}$ & 0,1 & $<\mathbf{0 , 0 1}$ \\
\hline Cromo Total & $\mathrm{mg} / \mathrm{L}$ & 5,0 & $<\mathbf{0 , 0 5}$ \\
\hline Estanho & $\mathrm{mg} / \mathrm{L}$ & 4,0 & $<\mathbf{0 , 2}$ \\
\hline Fenol & $\mathrm{mg} / \mathrm{L}$ & 0,5 & $\mathbf{0 , 0 8}$ \\
\hline Ferro Solúvel & $\mathrm{mg} / \mathrm{L}$ & 15,0 & $\mathbf{0 , 3}$ \\
\hline Fluoreto & $\mathrm{mg} / \mathrm{L}$ & 10,0 & $\mathbf{5 , 4}$ \\
\hline Manganês Solúvel & $\mathrm{mg} / \mathrm{L}$ & 1,0 & $\mathbf{0 , 0 3}$ \\
\hline Mercúrio & $\mathrm{mg} / \mathrm{L}$ & 0,01 & $\mathbf{0 , 0 5}$ \\
\hline Níquel & $\mathrm{mg} / \mathrm{L}$ & 2,0 & $\mathbf{0 , 1 7}$ \\
\hline Prata & $\mathrm{mg} / \mathrm{L}$ & 0,02 & $<\mathbf{0 , 0 2}$ \\
\hline Selênio & $\mathrm{mg} / \mathrm{L}$ & 0,02 & $\mathbf{0 , 0 1}$ \\
\hline Zinco & $\mathrm{mg} / \mathrm{L}$ & 5,0 & $\mathbf{0 , 0 7}$ \\
\hline Fonte: & Relatório Nova Ambi de análise de efluentes tratados - 23/09/2008) & \\
\hline
\end{tabular}

Fonte: (Relatório Nova Ambi de análise de efluentes tratados - 23/09/2008)

\subsection{Levantamento do balanço hídrico}

Com o levantamento das vazões de consumo durante todo o ano de 2007 , obtidas a partir da leitura dos hidrômetros instalados na edificações foi possível elaborar o 
balanço hídrico do consumo global e das áreas industriais e não industriais, sendo possível perceber quais processos apresentavam maior consumo.

Os balanços hídricos ficam mais facilmente compreendidos quando representados sobre fluxogramas da distribuição da água nos diversos setores. Assim se tem que:

- A figura 6.22 mostra a distribuição de água na empresa como um todo;

- A figura 6.23 mostra o consumo hídrico nos diversos setores e unidades prediais da empresa;

- A figura 6.24 mostra o consumo nos setores não industriais;

- A figura 6.25 mostra o consumo nos setores industriais. 


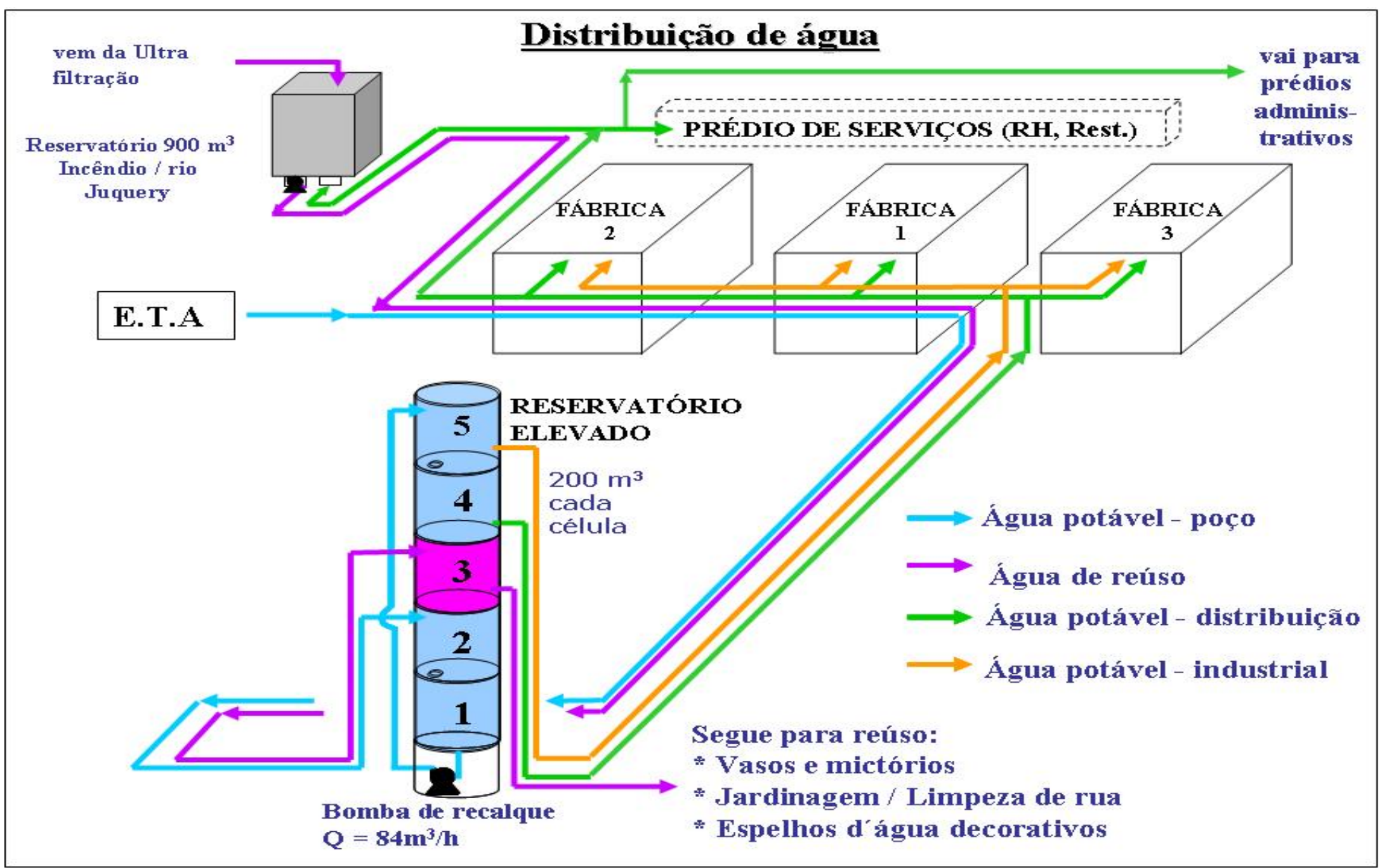

Figura 6.22 - Diagrama simplificado da distribuição de águas na empresa 
Balanço Hídrico Unidade Cajamar - ano 2007

- Consumo anual por edificação

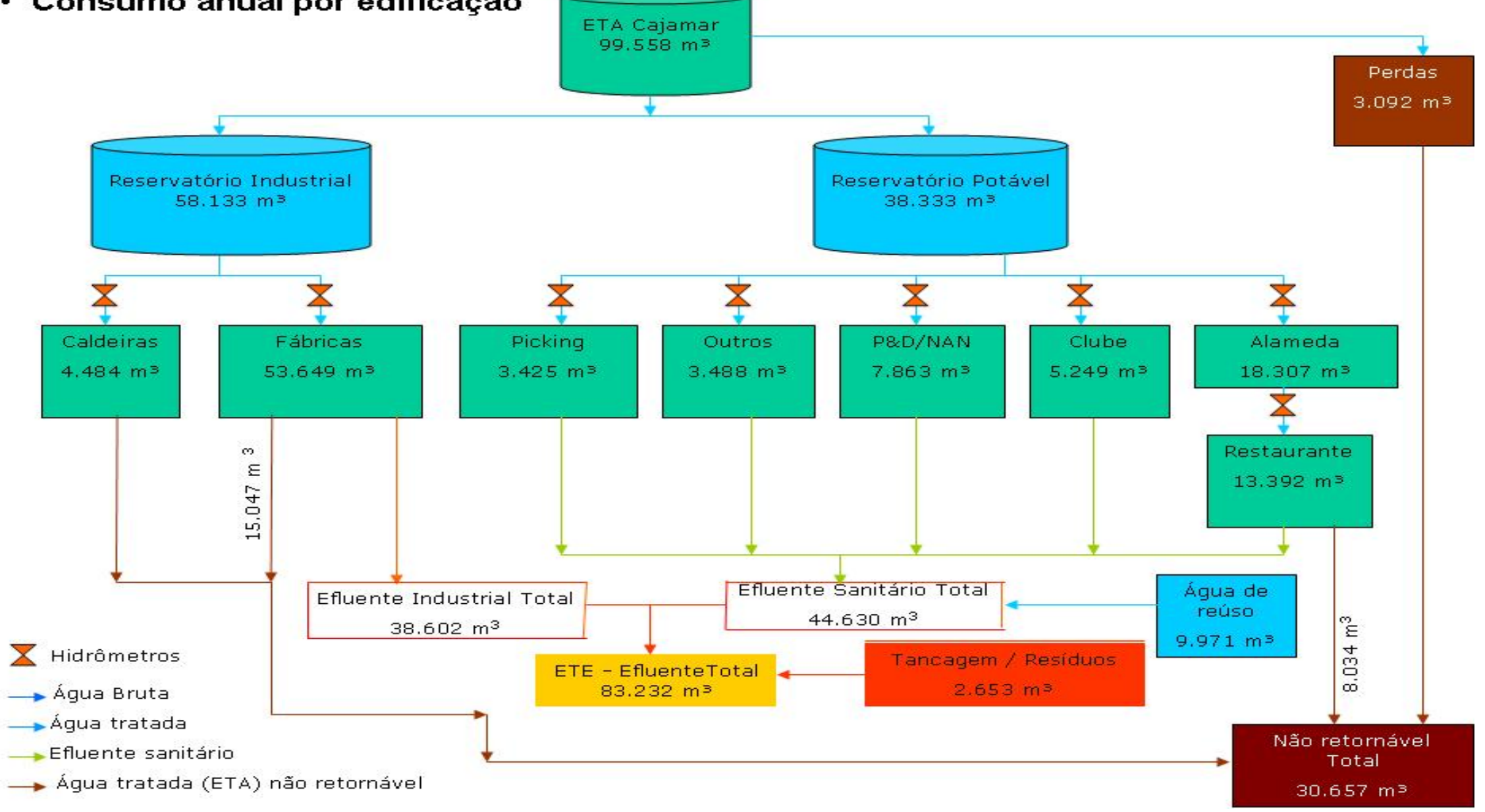

Figura 6.23 - Diagrama do balanço hídrico em toda a unidade Cajamar. 
Balanço Hídrico Unidade Cajamar - ano 2007

- Uso não industrial / efluente sanitário anual

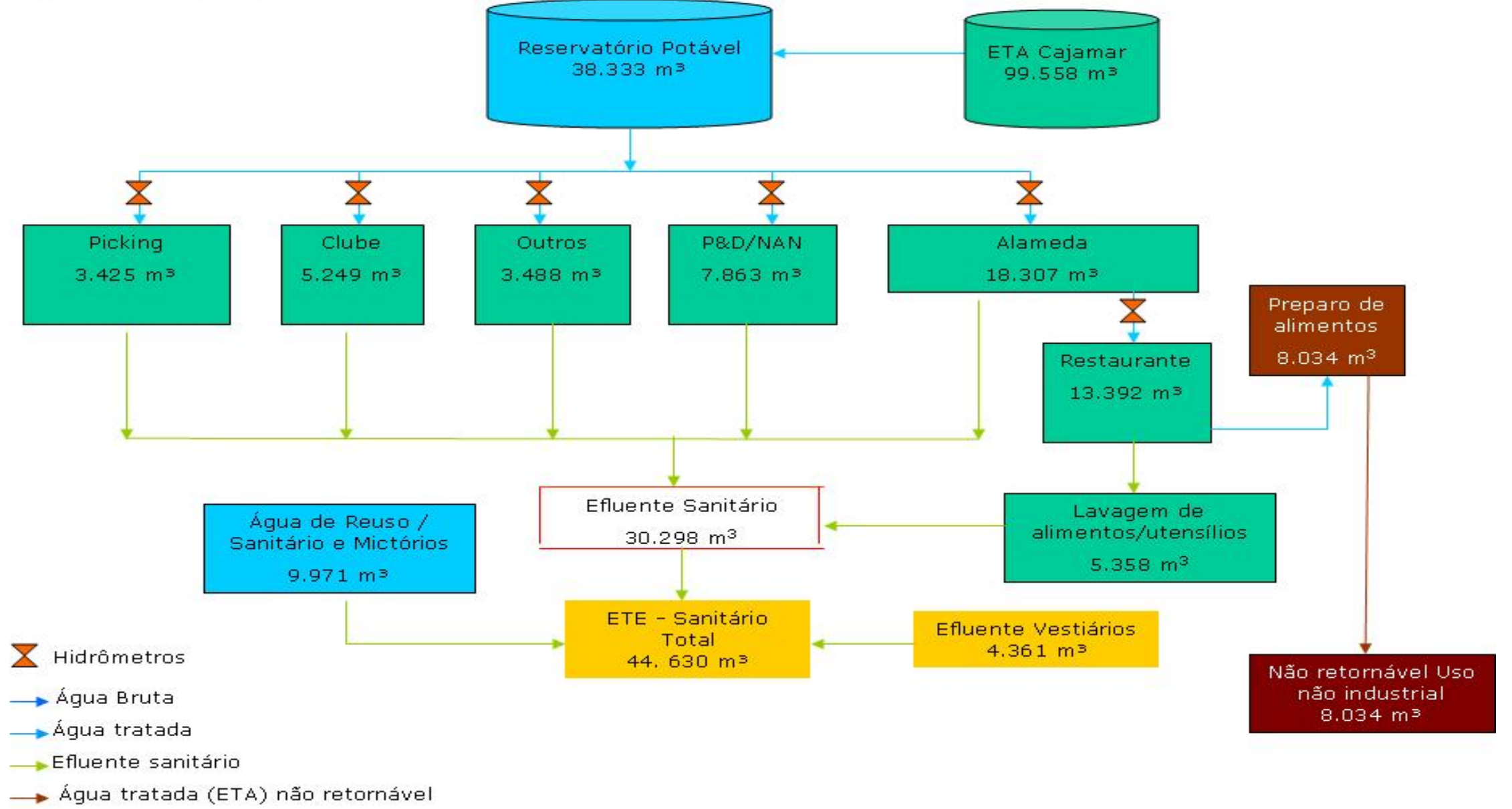

Figura 6.24 - Diagrama do balanço hídrico para os setores não industriais. 
Balanço Hídrico Unidade Cajamar - ano 2007

- Uso industrial / efluente industrial anual

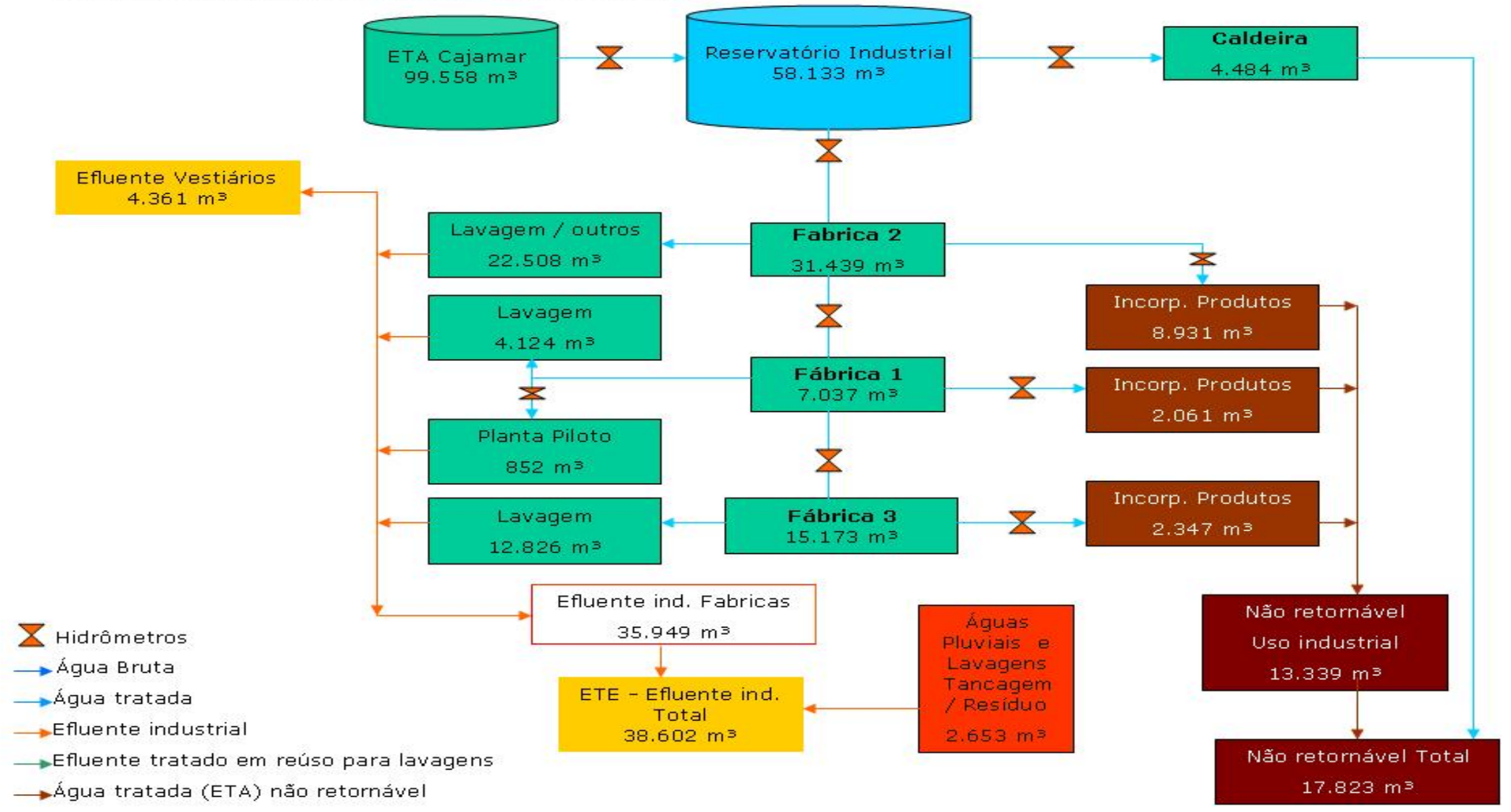

Figura 6.25 - Diagrama do balanço hídrico para os setores industriais 
Analisando-se os consumos apresentados no fluxograma da figura 6.23 encontramse os setores que são os maiores consumidores de água representados na figura 6.26.

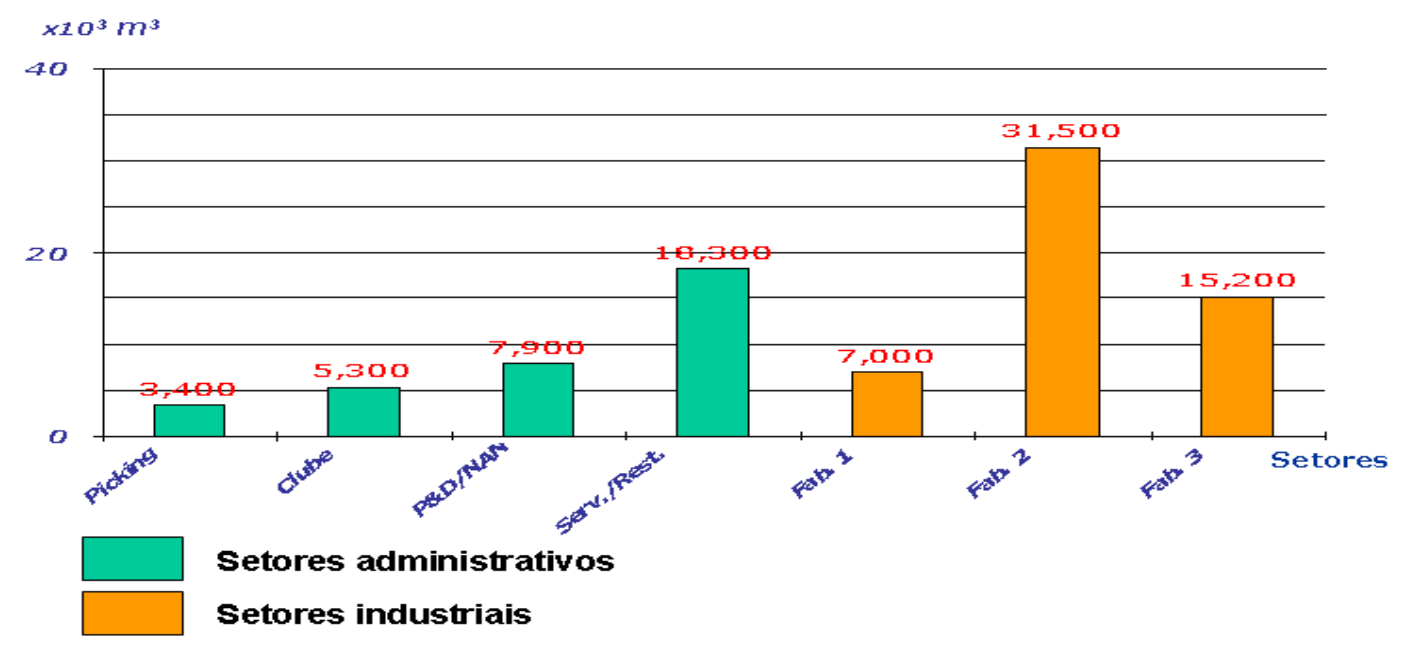

Figura 6.26 - Consumo anual dos diferentes setores da empresa

Com a tabela 6.6, em que os valores de consumo das fábricas estão somados, percebe-se a importância da água na fabricação de cosméticos.

Tabela 6.6 - Lista dos setores da empresa e seus consumos de água

\begin{tabular}{lr}
\multicolumn{1}{c}{ Setor } & $\begin{array}{c}\text { Consumo anual } \\
\left(\mathbf{m}^{3}\right)\end{array}$ \\
\hline Fábricas & 53.649 \\
\hline Alameda (Prédio de Serviços+Restaurante, etc.) & 18.307 \\
\hline Prédio P\&D / NAN & 7.863 \\
\hline Clube & 5.249 \\
\hline Picking (Armazenamento/Distribuição) & 3.425 \\
\hline Outros setores administrativos & 3.425 \\
\hline
\end{tabular}




\section{Considerações sobre o consumo doméstico}

A figura 6.26 mostra que o consumo para fins domésticos, considerando-se as áreas administrativas e restaurante, é razoavelmente alto, em função do grande número de empregados. Porém, como esse consumo é estável, bem definido e proporcional à população existente na empresa, considerou-se que as chances de obtenção de economias seriam mais difíceis pois para esse tipo de consumo a empresa já adota as medidas abaixo:

- o uso do sistema a vácuo para a coleta dos esgotos sanitários;

- o reúso de efluente tratado para os vasos sanitário e mictórios;

- torneiras com sistema de retorno do acionador da válvula, por mola ou com sensor de proximidade;

- campanhas de conscientização dos empregados para que se comprometam com as ações de racionalização e economia de água;

- sinalizações de orientação em banheiros e vestiários.

Esse é o caso do Prédio de Serviços, onde estão áreas administrativas e de apoio como Recursos Humanos, banco, Tecnologia da Informação, Comunicações, Ambulatório Médico, Berçário e Restaurante. O mesmo vale para os prédios de Pesquisa \& Desenvolvimento e o de Treinamento (NAN).

É importante acrescentar que aliado a implantação dos dispositivos que limitam o consumo de água foi implementado um programa de manutenção preventiva que garante o funcionamento desses sistemas.

\section{$\underline{\text { Consumo industrial }}$}

A busca por novas oportunidades de economias através da conservação ou reúso deve levar em conta os processos industriais com maior consumo de água.

Nas atividades internas às fábricas, onde não existiam medidores diretos, foi possível quantificar os volumes envolvidos nas muitas atividades, através de 
informações sobre os níveis de produção e as quantidades de água empregadas em cada "batelada" ou da quantificação dos volumes utilizados em processos de limpeza e sanitização de reatores, tanques e tubulações. Essa quantificação foi realizada calculando-se o volume de tanques e reatores e verificando-se os níveis alcançados pela água quando das atividades de limpeza e sanitização. Também avaliou-se os consumos através da coleta da água utilizada ao final desses processos de limpeza e sanitização, quando são enviadas aos tanques pulmão para efluentes.

Após o entendimento da complexidade dos diversos processos da empresa ficou claro que o estudo deveria concentrar-se em parte destes e não na empresa como um todo.

O maior consumidor de água é o setor de Produção representado pelas fábricas. Desse modo escolheu-se o setor industrial como o objetivo central do estudo.

\subsection{Identificação dos processos industriais de maior consumo de água}

Analisando-se o consumo nos setores industriais, utilizando-se os valores de consumo anual representados na figura 6.25 , encontram-se os resultados para as principais áreas desse setor, apresentados na tabela 6.7:

Tabela 6.7 - Lista dos setores industriais e seus consumos de água

\begin{tabular}{lr}
\multicolumn{1}{c}{ Setor } & $\begin{array}{c}\text { Consumo anual } \\
\left(\mathbf{m}^{\mathbf{3}}\right)\end{array}$ \\
\hline Fábrica 2 & 31.439 \\
\hline Fábrica 3 & 15.173 \\
\hline Fábrica 1 & 7.037 \\
\hline Central de Utilidades (Caldeiras) & 4.484 \\
\hline
\end{tabular}


Verifica-se que os processos com maior consumo são os referentes à fabricação de cosméticos na Fábrica 2. Nesses processos, devido às características das matériasprimas e dos produtos cosméticos finais (cremes, condicionadores, etc.), grande quantidade de resíduos fica agregada às superfícies dos equipamentos de fabricação.

Como a fabricação dos diferentes produtos é realizada em batelada, as operações de lavagem e de sanitização ("set up's") se repetem a cada lote de fabricação, sendo portanto consideradas as maiores consumidoras de água potável e água purificada.

Também na Fabrica 3 o consumo é alto devido aos mesmos motivos indicados para a Fábrica 2.

Na Fábrica 1, onde se produzem perfumes, colônias e desodorantes, produtos esses que têm baixa viscosidade e são de fácil limpeza, o consumo de água é bastante inferior. Também as necessidades de sanitização são menores uma vez que na composição de tais produtos é utilizado álcool etílico em faixas variando de 70 a 90 \%, reduzindo o risco de contaminação microbiológica e, conseqüentemente, a necessidade de operações de limpeza e sanitização freqüentes.

\section{Escolha do objeto de estudo}

Com base nos balanços hídricos foi escolhida portanto a Fábrica 2 como objeto de estudo para se quantificar a economia possível com medidas para conservação de água, através de estudo dos processos de produção.

Para a Fábrica 3 optou-se em estudar a economia possível com a utilização de sistema de limpeza de reatores CIP (“cleaning in place").

\subsubsection{Utilização de água no processo com maior consumo na Fábrica 2}

Praticamente todo o consumo de água na Fábrica 2, excetuando-se o que é incorporado aos produtos fabricados, é devido aos processos de limpeza e sanitização de equipamentos. Isso pode ser verificado na figura 6.25 que mostra que $22.508 \mathrm{~m}^{3}$ do total de $31.439 \mathrm{~m}^{3}$ são consumidos nessas operações, ou seja $71,6 \%$. 


\subsubsection{Avaliação do processo de lavagem e sanitização - "set up" na Fábrica 2}

Os equipamentos de processo na Fábrica 2 são basicamente reatores, tanques de armazenamento e tubulações para transferência (ver figura 6.27 e 6.28).

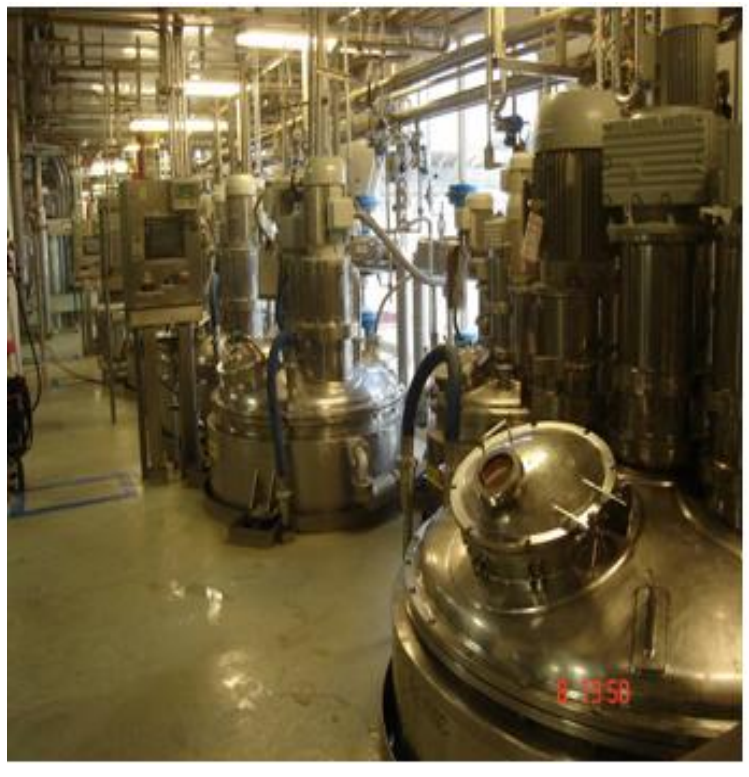

Figura 6.27 - Reatores de fabricação

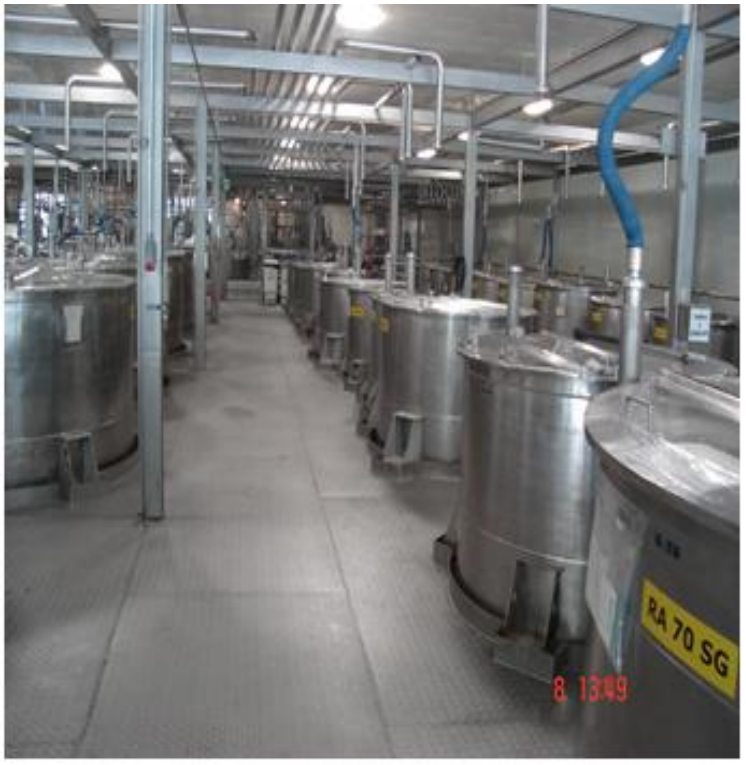

Figura 6.28 - Tanques de armazenamento

\section{Lavagem e sanitização de equipamentos}

Após a fabricação, todos os equipamentos devem ser lavados e sanitizados, para que possam ser utilizados em outros lotes de produção.

Os processos de lavagem e sanitização são os maiores consumidores de água na área industrial. Constituem as operações de limpeza e sanitização de tanques de preparação e fabricação de cosméticos (reatores), bem como a limpeza e sanitização dos tanques de armazenamento destes, tubulações e equipamentos usados na transferência dos produtos. Essas operações são conhecidas como "limpeza e set up's" de equipamentos. 
A característica principal do segmento industrial de cosméticos é justamente a grande variabilidade dos produtos fabricados. Assim muitos dos equipamentos utilizados na fabricação devem ser versáteis e "multi-propósitos", tendo que se ajustar às diferentes características de cada produto.

A limpeza "CIP" é uma das opções que a empresa emprega e está em teste apenas em dois equipamentos automatizados, de pequena capacidade, cujos produtos, neles fabricados, apresentam características semelhantes e lotes de pequeno volume (300 a $700 \mathrm{~kg})$.

Algumas matérias primas e mesmo alguns produtos finais apresentam elevada viscosidade (até $200.000 \mathrm{cP}$ medidos em viscosímetros e até $800.000 \mathrm{cP}$ medidos em penetrômetros) e a característica de secar e formar placas aderentes aos pontos de difícil acesso tais como partes do sistema de agitadores, chicanas, etc., como nas figuras 6.29 e 6.30 .

Uma das formas encontradas para minimizar a quantidade de resíduos viscosos em tubulações é a pré-limpeza destas com disparo de "balas" de com ar comprimido isento de óleos e impurezas (a 4 Bar). Para isso é necessário que as tubulações possuam diâmetros uniformes, com o mínimo de interferências e mudanças de direção, de forma a permitir o deslizamento da "bala" até o ponto de saída onde um recipiente coletor recupera a "bala" e os resíduos. Isso além de retirar materiais agregados às superfícies das tubulações, reduz a carga de sujidades que deverá ser retirada na operação de limpeza convencional. Essa operação de pré-limpeza com ar comprimido é sugerida no estudo de Alvarez et al. (2004).

Muitas vezes, para os tanques grandes, é necessário que o operador entre em seu interior e faça a limpeza manualmente (retirada de placas agregadas), o que demanda maiores cuidados com a segurança do próprio operador para evitar acidentes e maior tempo dedicado a essa atividade. 


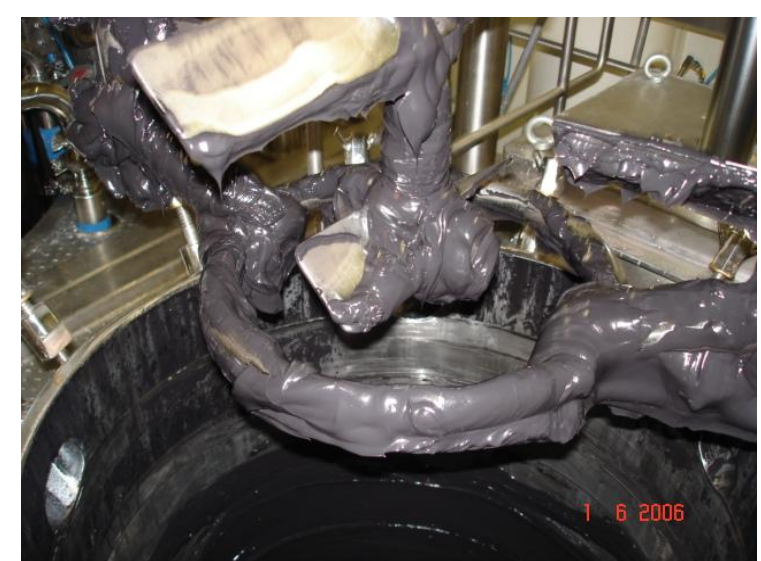

Figura 6.29 - Agitador impregnado com produto

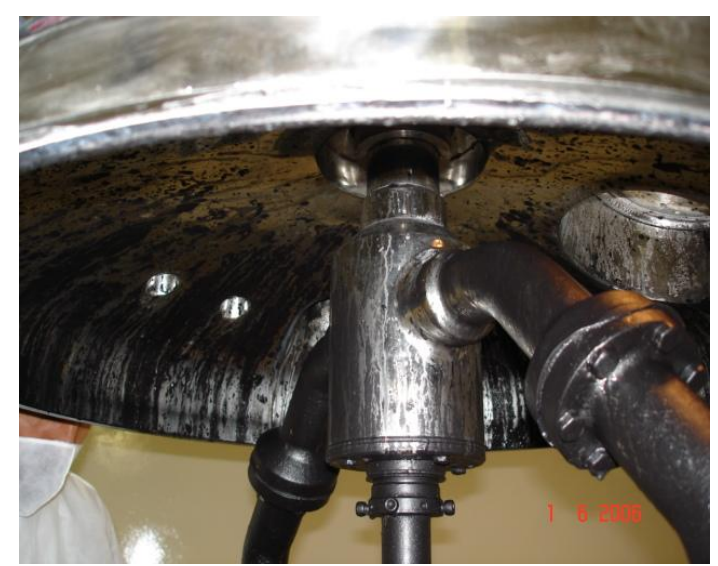

Figura 6.30 - Tampa impregnada com produto

Descrição das operações de lavagem e sanitização de reatores e tanques

1) lavagem com água potável a $40^{\circ} \mathrm{C}$ com jato de pressão (máquina Kärcher);

2) carregamento de $50 \%$ da capacidade do reator com água potável, seguido de aquecimento a $65^{\circ} \mathrm{C}$, com agitação por $2 \mathrm{~h}$;

3) sanitização com aspersão de solução de ácido acético/ácido peracético/peróxido de hidrogênio, com jato de pressão à temperatura ambiente (máq. Kärcher), por $30 \mathrm{~min}$;

4) enxágüe com água desmineralizada ou da OR, sob pressão (máq. Kärcher) e a temperatura ambiente;

5) fechamento do tanque.

Consumos nas atividades na lavagem e sanitização de reatores - exemplo Reator de $7.000 \mathrm{~L}$ (por operação)

1) lavagem com água potável (AP) enxágüe a $40^{\circ} \mathrm{C}$ com jato de pressão (máq. Kärcher) - consumo de 300 a $500 \mathrm{~L}====>\mathrm{C} 1=400 \mathrm{~L}$

2) carregamento de $50 \%$ da capacidade com água potável, seguido de aquecimento a $65^{\circ} \mathrm{C}$, com agitação por $2 \mathrm{~h}-$ consumo de $3.500 \mathrm{~L}====>\mathrm{C} 2=3.500 \mathrm{~L}$ 
3) sanitização com solução de ácido acético/ácido peracético/peróxido de hidrogênio, com jato de pressão a temperatura ambiente (máq. Kärcher), por 30 min. - consumo de $200 \mathrm{~L}====>$ C3 $=200 \mathrm{~L}$

4) enxágüe com água desmineralizada ou da $O R$, sob pressão (máq. Kärcher) e a temperatura ambiente - consumo de 20 a $80 \mathrm{~L}====>\mathbf{C 4}=\mathbf{5 0} \mathrm{L}$

5) fechamento do tanque

Total de água consumida $=$ cerca de 4.150 L por operação

Obs.: a variação existente para os consumos é devido aos diferentes produtos fabricados que exigem maior ou menor quantidade de água, conforme a dificuldade de limpeza que apresentam. Assim adotou-se o valor médio dentro da faixa de consumo.

Utilizando-se o mesmo procedimento de cálculo para os outros reatores existentes nessa fábrica, chega-se aos valores totais apresentados na tabela 6.8:

Tabela 6.8 - Consumos de água para limpeza e sanitização de reatores

\begin{tabular}{|c|c|c|c|c|}
\hline $\begin{array}{c}\text { Reator } \\
\text { (capacidade } \mathrm{em} \mathrm{m}^{3} \text { ) }\end{array}$ & Quantidade & Operação & $\begin{array}{l}\text { Consumo na } \\
\text { operação (L) }\end{array}$ & $\begin{array}{l}\text { Consumo } \\
\text { total (L) }\end{array}$ \\
\hline \multirow{4}{*}{$7 \mathrm{~m}^{3}$} & \multirow{4}{*}{4} & lavagem c/ AP & 400 & 1.600 \\
\hline & & carregamento & 3.500 & 14.000 \\
\hline & & sanitização & 200 & 800 \\
\hline & & enxágüe & 50 & 200 \\
\hline \multirow{4}{*}{$5 \mathrm{~m}^{3}$} & \multirow{4}{*}{3} & lavagem c/ AP & 286 & 858 \\
\hline & & carregamento & 2.500 & 7.500 \\
\hline & & sanitização & 143 & 429 \\
\hline & & enxágüe & 36 & 108 \\
\hline \multirow{4}{*}{$3 \mathrm{~m}^{3}$} & \multirow{4}{*}{3} & lavagem c/ AP & 171 & 513 \\
\hline & & carregamento & 1.500 & 4.500 \\
\hline & & sanitização & 86 & 258 \\
\hline & & enxágüe & 21 & 63 \\
\hline
\end{tabular}


Tabela 6.8 - Consumos de água para limpeza e sanitização de reatores (continuação)

\begin{tabular}{|c|c|c|c|c|}
\hline $\begin{array}{c}\text { Reator } \\
\text { (capacidade em } \mathrm{m}^{3} \text { ) }\end{array}$ & Quantidade & Operação & $\begin{array}{l}\text { Consumo na } \\
\text { operação (L) }\end{array}$ & $\begin{array}{c}\text { Consumo } \\
\text { total (L) }\end{array}$ \\
\hline & & lavagem c/ AP & 114 & 114 \\
\hline \multirow[t]{4}{*}{$2 \mathrm{~m}^{3}$} & 1 & carregamento & 1.000 & 1.000 \\
\hline & & sanitização & 57 & 57 \\
\hline & & enxágüe & 14 & 14 \\
\hline & & lavagem c/ AP & 57 & 171 \\
\hline \multirow[t]{4}{*}{$1 \mathrm{~m}^{3}$} & 3 & carregamento & 500 & 1.500 \\
\hline & & sanitização & 29 & 87 \\
\hline & & enxágüe & 7 & 21 \\
\hline & & lavagem c/ AP & 29 & 58 \\
\hline \multirow[t]{4}{*}{$0,5 \mathrm{~m}^{3}$} & 2 & carregamento & 250 & 500 \\
\hline & & sanitização & 14 & 28 \\
\hline & & enxágüe & 4 & 8 \\
\hline & \multicolumn{2}{|c|}{ TOTAL } & & 34.387 \\
\hline
\end{tabular}

Considerando-se que existem 14 reatores na Fábrica 2, tem-se um consumo médio de $2.456 \mathrm{~L}$.

Considerando-se também que são realizadas cerca de 700 operações por mês para "set up's" em reatores, chega-se ao volume estimado total consumido no mês, conforme a tabela 6.9.

Tabela 6.9 - Volumes totais consumidos na limpeza e sanitização dos reatores

\begin{tabular}{ccc}
\hline $\begin{array}{c}\text { Volume médio consumido } \\
\text { por operação }\left(\mathrm{m}^{3}\right)\end{array}$ & $\begin{array}{c}\mathbf{N}^{\circ} \text { médio de } \\
\text { operações por } \\
\text { mês }\end{array}$ & $\begin{array}{c}\text { Volume total consumido no mês } \\
\left(\mathrm{m}^{3}\right)\end{array}$ \\
\hline 2,456 & 700 & $\mathbf{1 . 7 1 9}$ \\
\hline
\end{tabular}

Volume total consumido por mês $=1.719 \mathrm{~m}^{3} /$ mês para "set up" de reatores 
Consumos nas atividades na lavagem e sanitização de tanques de armazenamento - exemplo tanque de $7.000 \mathrm{~L}$

O volume consumido é menor pois são tanques mais simples, sem agitadores ou componentes que dificultem a limpeza e não necessitando preencher seu volume até a metade. As outras etapas são semelhantes.

1) lavagem com água potável (AP) e enxágüe a $40^{\circ} \mathrm{C}$ com jato de pressão (máq. Kärcher) - consumo de 300 a $500 \mathrm{~L}====>$ C1 $=400 \mathrm{~L}$

2) sanitização com solução de ácido acético lácido peracético /peróxido de hidrogênio, com jato de pressão a temperatura ambiente (máq. Kärcher), por 30 min. - consumo de $200 \mathrm{~L}====>$ C3 $=200 \mathrm{~L}$

3) enxágüe com água desmineralizada ou da $O R$, sob pressão (máq. Kärcher) e a temperatura ambiente - consumo de 20 a $80 \mathrm{~L}====>$ C4 $=50 \mathrm{~L}$

4) fechamento do tanque

Total de água consumida $=$ cerca de $650 \mathrm{~L}$ por operação

Obs.: a variação existente para os consumos é devido aos diferentes produtos fabricados que exigem maior ou menor quantidade de água, conforme a dificuldade de limpeza que apresentam. Assim adotou-se o valor médio dentro da faixa de consumo.

Utilizando-se o mesmo procedimento de cálculo para os outros tanques de armazenamento existentes nessa fábrica, chega-se aos valores totais apresentados na tabela 6.10:

Tabela 6.10 - Consumos de água para limpeza e sanitização de tanques de armazenamento

\begin{tabular}{cccrrr}
\hline $\begin{array}{c}\text { Tq. de } \\
\text { armazenamento } \\
\text { (capacidade em } \mathbf{~ m}^{3} \text { ) }\end{array}$ & Quantidade & Operação & \multicolumn{1}{c}{$\begin{array}{c}\text { Consumo na } \\
\text { operação } \\
\text { (L) }\end{array}$} & $\begin{array}{c}\text { Consumo } \\
\text { total } \\
\text { (L) }\end{array}$ \\
\hline 7 m $^{3}$ & 9 & lavagem c/ AP & 400 & 3.600 \\
\cline { 3 - 6 } & sanitização & 200 & 1.800 \\
\hline & enxágüe & 50 & 450 \\
\hline
\end{tabular}


Tabela 6.10 - Consumos de água para limpeza e sanitização de tanques de armazenamento (continuação)

\begin{tabular}{|c|c|c|c|c|}
\hline $\begin{array}{c}\text { Tq. de } \\
\text { armazenamento } \\
\text { (capacidade em } \mathrm{m}^{3} \text { ) }\end{array}$ & Quantidade & Operação & $\begin{array}{l}\text { Consumo na } \\
\text { operação } \\
\text { (L) }\end{array}$ & $\begin{array}{c}\text { Consumo } \\
\text { total } \\
\text { (L) }\end{array}$ \\
\hline \multirow{3}{*}{$5 \mathrm{~m}^{3}$} & \multirow{3}{*}{4} & lavagem c/ AP & 286 & 1.144 \\
\hline & & sanitização & 143 & 572 \\
\hline & & enxágüe & 36 & 144 \\
\hline \multirow{3}{*}{$3 \mathrm{~m}^{3}$} & \multirow{3}{*}{16} & lavagem c/ AP & 171 & 2.736 \\
\hline & & sanitização & 86 & 1.376 \\
\hline & & enxágüe & 21 & 336 \\
\hline \multirow{3}{*}{$2 \mathrm{~m}^{3}$} & \multirow{3}{*}{4} & lavagem c/ AP & 114 & 456 \\
\hline & & sanitização & 57 & 228 \\
\hline & & enxágüe & 14 & 56 \\
\hline \multirow{3}{*}{$1 \mathrm{~m}^{3}$} & \multirow{3}{*}{3} & lavagem c/ AP & 57 & 171 \\
\hline & & sanitização & 29 & 87 \\
\hline & & enxágüe & 7 & 21 \\
\hline \multicolumn{3}{|c|}{ TOTAL } & & 13.177 \\
\hline
\end{tabular}

Considerando que existem 36 tanques de armazenamento na Fábrica 2, tem-se um consumo médio de $366 \mathrm{~L}$.

Considerando também que são realizadas cerca de 130 operações por mês para "set up's" em tanques de armazenamento, chega-se ao volume estimado total consumido no mês, conforme a tabela 6.11 .

Tabela 6.11 - Volumes totais consumidos na limpeza e sanitização de tanques de armazenamento

\begin{tabular}{ccc}
\hline $\begin{array}{c}\text { Volume médio consumido } \\
\text { por operação (L) }\end{array}$ & $\begin{array}{c}\mathbf{N}^{\circ} \text { médio de } \\
\text { operações por } \\
\text { mês }\end{array}$ & Volume total consumido no mês \\
366 & 130 & $\mathbf{4 7}$ \\
\hline
\end{tabular}

Volume total consumido por mês $=47,6 \mathrm{~m} / \mathrm{mês}$ para "set up" de tanques de armazenamento 
Consumos nas atividades na lavagem e sanitização de tubulações

Para as tubulações das 7 linhas de envase existentes, são necessários $200 \mathrm{~L}$ de água por operação, com cerca de 160 operações por mês. Então:

O volume total consumido por mês é de $32 \mathrm{~m}^{3}$ para set up das linhas

Com os dados acima é possível determinar o consumo total de água para as operações de limpeza e sanitização na Fábrica 2, sintetizados na tabela 6.12.

Tabela 6.12 - Consumo total de água para as operações de limpeza e sanitização na Fábrica 2

\begin{tabular}{cc}
\hline $\begin{array}{c}\text { Operação de set up } \\
\text { em }\end{array}$ & $\begin{array}{c}\text { Consumo mensal } \\
\left(\mathbf{m}^{\mathbf{3}} \mathbf{)}\right.\end{array}$ \\
\hline Reatores & 1.719 \\
\hline $\begin{array}{c}\text { Tanques de } \\
\text { armazenamento }\end{array}$ & 47,6 \\
\hline Tubulações & 32 \\
\hline TOTAL & $\mathbf{1 . 7 9 8 , 6}$ \\
\hline
\end{tabular}

Valor total do consumo de $1.798,6 \mathrm{~m}^{3} / \mathrm{mês}$ nas operações de lavagem e sanitização na Fábrica 2.

Isso leva a um consumo anual de $21.583,2 \mathrm{~m}^{3}$, o que corresponde a cerca de $69 \%$ do consumo total da Fábrica 2.

\subsection{Considerações sobre outras possibilidades de conservação de água}

Considerando para a indústria de cosméticos as recomendações presentes no trabalho Água na indústria - uso racional e reúso (MIERZWA; HESPANHOL, 2005), 
mais importante do que encontrar uso para efluentes tratados, é descobrir oportunidades para economia no consumo de água, seja ela potável ou purificada, através de mudanças no processo produtivo, modificações em equipamentos que reduzam a necessidade de água, eliminação de desperdícios, controle de perdas através de programas de manutenção de equipamentos, e também treinamento e comprometimento de operadores.

Baseado nas informações coletadas, descrição dos procedimentos operacionais e também observação da forma como as atividades são realizadas pelos operadores, listou-se fatores que levam ao consumo desnecessário que podem ser oportunidades de economias importantes.

\subsubsection{Lotes de produção}

Verificou-se que os lotes produzidos muitas vezes são intercalados por produtos diferentes o que obriga a limpeza e sanitização a cada mudança de produto.

Necessário então uma melhor coordenação entre as áreas de Produção, de Pesquisa e Desenvolvimento e de Planejamento de Controle Logístico, de forma a se ter a produção de lotes seqüenciados, o que diminuiria a necessidade de "set up's" seguidos.

Apesar de ser uma medida importante, a experiência da operação de lotes contínuos mostrou que se poderiam repetir as bateladas de um mesmo produto por até 3 vezes. Acima disso, por exemplo, corre-se o risco de ocorrer o desprendimento de placas de algumas matérias primas agregadas a pontos mortos do reator e que também podem ser foco de contaminação microbiológica, comprometendo a qualidade do produto final.

Foram realizados testes simulados com um determinado produto hidratante, caso o mesmo fosse produzido em seqüência de até 3 lotes, considerando que são produzidos até 192 lotes por mês utilizando três reatores específicos A, B e C. Os resultados estão apresentados na tabela 6.13: 
Tabela 6.13 - Consumos de água e detergente para limpezas seqüenciais nos reatores $A, B$ e $C$, na Fábrica 2

\begin{tabular}{|c|c|c|c|}
\hline & $\begin{array}{l}\text { Para } 1 \text { lote } \\
\text { simples }\end{array}$ & $\begin{array}{l}\text { Para } 2 \text { lotes } \\
\text { seqüenciais }\end{array}$ & $\begin{array}{l}\text { Para } 3 \text { lotes } \\
\text { seqüenciais }\end{array}$ \\
\hline $\mathrm{N}^{\circ}$ de limpezas & 192 & 96 & 64 \\
\hline Consumo de água (L) & 384.000 & 192.000 & 128.000 \\
\hline $\begin{array}{l}\text { Consumo de detergente } \\
\qquad(\mathrm{L})\end{array}$ & 2.880 & 1.440 & 960 \\
\hline Economia de água $(L)$ & & 192.000 & 256.000 \\
\hline Economia de água (\%) & & $50 \%$ & $67 \%$ \\
\hline $\begin{array}{l}\text { Economia de detergente } \\
\qquad(\mathrm{L})\end{array}$ & & 1.440 & 1.920 \\
\hline
\end{tabular}

Com lotes contínuos de até 3 vezes pode-se ter uma economia média de $1,3 \mathrm{~m}^{3}$ a cada lote, ou seja economia de $67 \%$. Essa conclusão está em acordo com os resultados do estudo de ALVAREZ et al (2004), que obteve reduções de $60 \%$ a 90 $\%$ no consumo de água utilizada em processos de limpeza de reatores e tanques em indústria de detergente e amaciantes.

\subsubsection{Existência de reatores de pequena capacidade}

Os reatores pequenos às vezes são empregados para produção de produtos que, se fabricados em equipamentos maiores, poderiam ter um número menor de lotes e, conseqüentemente, um número menor de operações de "set up's". Existe já uma preocupação nesse sentido mas, devido à grande diversidade de produtos cujas demandas de vendas somam quantidades totais de pequenos volumes, a fabricação dos mesmos em reatores de maior capacidade se torna inviável. 


\subsubsection{Comportamento e cumprimento de procedimentos pelos operadores}

Foi verificado que se um reator ou tanque ficar aguardando mais de duas horas o processo de limpeza, a quantidade de água empregada será maior devido à secagem e maior agregação de placas ou filmes de matérias primas às superfícies. Foi verificado que operadores, quando próximo do fim de seu turno de trabalho, às vezes acabam deixando para os colegas do próximo turno essa operação que é considerada trabalhosa. Isso leva a um desperdício evidente.

Também se verificou que às vezes, quando um operador executa operações simultâneas, ele acaba deixando de lado o cuidado com o desperdício. Assim foram observadas mangueiras de água potável despejando água para dentro de reator, além do volume necessário ao processo de limpeza, enquanto o operador cuidava de outra atividade.

\subsubsection{Sistema de recirculação durante a lavagem inicial}

Considerando-se a impossibilidade de se armazenar as águas de lavagem para posterior uso no início do processo em outra operação, devido à facilidade de proliferação microbiológica, verificou-se a possibilidade de se recircular a própria água no início de cada operação com máquina de pressão. Isso seria realizado enquanto se quer retirar materiais depositados no início da operação, enviando-se essa água normalmente para a ETE, porém com uma concentração maior e em menor volume.

A reutilização da água de lavagem está em acordo com o sugerido por Zotter (2004) como uma das ações integradas para se diminuir a quantidade de efluente a ser tratado. Porém essa ação deve ser estudada com cuidado em função de que a máquina empregada para o jateamento (Kärcher) eleva a temperatura até $40{ }^{\circ} \mathrm{C} \mathrm{e}$ com isso pode-se ter problemas com depósitos em tubulações e mangueiras do sistema ou mesmo a possibilidade de focos de contaminação microbiológica. 
Caso possível, para o reator de $7.000 \mathrm{~L}$, se poderia economizar cerca de 2/3 do volume empregado nessa atividade inicial que é de $400 \mathrm{~L}$, ou seja, economia de 266 L a cada "set up" para esse reator.

\subsubsection{Utilização de detergente específico que auxilie a dissolução das placas agregadas}

O motivo de se colocar água até a metade dos reatores é a necessidade da limpeza de agitadores e homogeneizadores internos que possuem partes de difícil acesso aos jatos de pressão. Com o uso de um detergente especial inicialmente seria feito um enxágüe com o mesmo que agiria sobre as placas e depósitos facilitando a sua limpeza com jatos de pressão. Essa medida está em acordo com as recomendações de Alvarez et al. (2004) quanto à necessidade de busca de novos procedimentos de limpeza que levem ao menor consumo de água.

A figura 6.31 mostra fotos do sistema de pulverização de detergente especial, incluindo dispositivo pulverizador em forma de bengala, e do conjunto de agitação e mistura de um dos reatores, mostrando a dificuldade de acesso.

No entanto é necessário que se tomem alguns cuidados devido:

1) O risco aos operadores pela maior agressividade de tal produto devido a sua corrosividade;

2) O risco aos equipamentos que também podem sofrer ataque químico e ter componentes com deterioração prematura;

3) As substâncias componentes do produto podem aumentar a carga poluidora dos efluentes a serem tratados. 

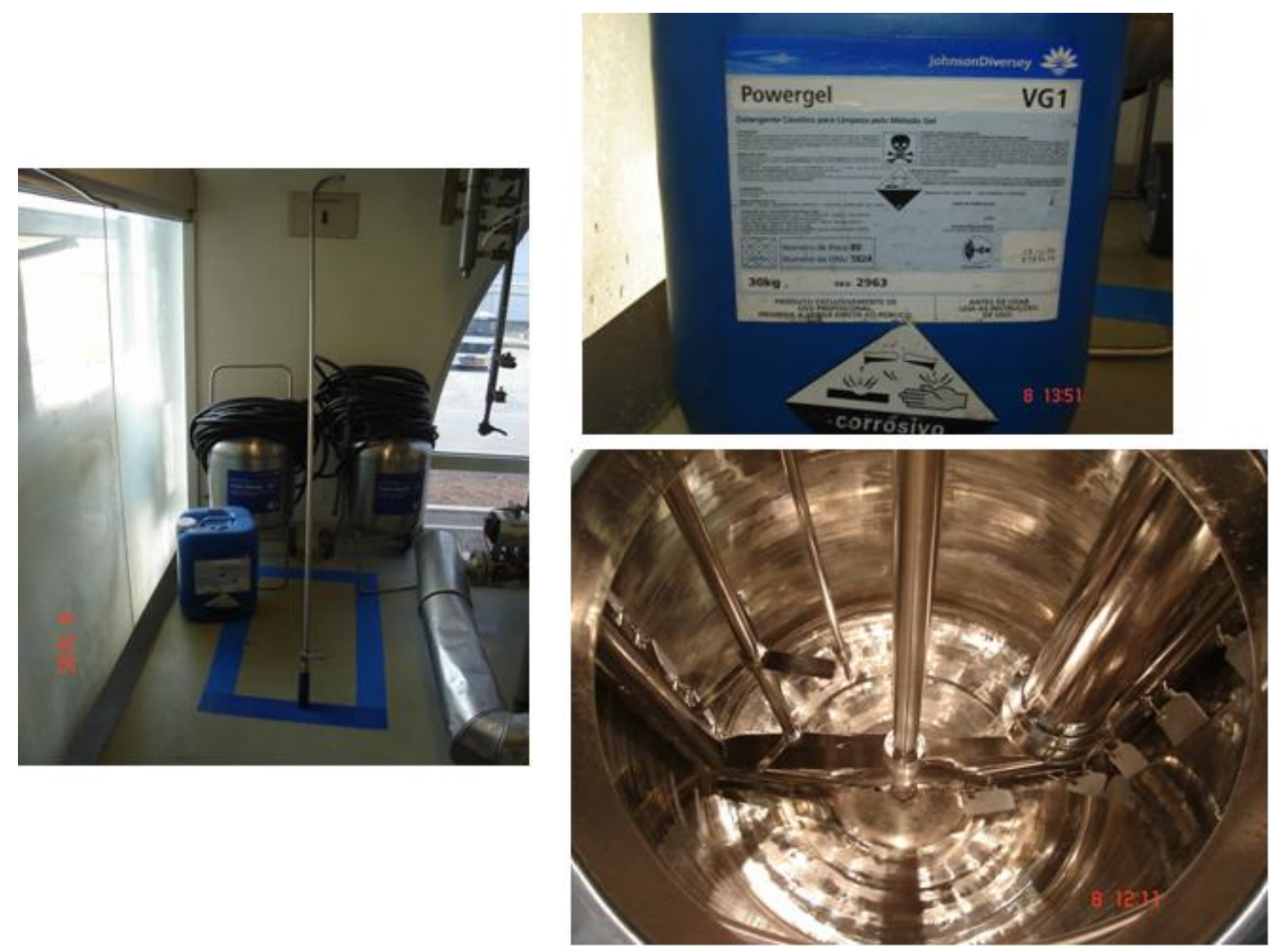

Figura 6.31 - Sistema de pulverização de detergente especial e do conjunto de agitação de um reator.

Caso o estudo e ensaios com o produto sejam positivos pode-se eliminar a necessidade de preenchimento com água até a metade dos reatores para a limpeza. Isto traria grande economia com redução de $4.150 \mathrm{~L}$ para apenas $650 \mathrm{~L}$ totais para cada operação em reator de 7.000 L, redução portanto de $83 \%$ do consumo nesta atividade.

Considerando os valores de consumo com o processo de limpeza habitual, se implantado o sistema descrito com uso de detergente e dispositivo de pulverização especiais para limpeza de todos os reatores, o consumo total indicado na tabela 6.12 poderia cair em até $80 \%$, conforme sintetizado na tabela 6.14 : 
Tabela 6.14 - Consumo total de água para limpeza e sanitização dos reatores e tanques de armazenamento

\begin{tabular}{ccc}
\hline $\begin{array}{c}\text { Operação de set up } \\
\text { em: }\end{array}$ & $\begin{array}{c}\text { Consumo mensal } \\
\left(\mathbf{m}^{\mathbf{3}}\right)\end{array}$ & $\begin{array}{c}\text { Consumo mensal } \\
\text { com redução } \\
\left(\mathbf{m}^{3}\right)\end{array}$ \\
\hline Reatores & 1.719 & 275 \\
\hline $\begin{array}{c}\text { Tanques de } \\
\text { armazenamento }\end{array}$ & 47,6 & 47,6 \\
\hline Tubulações & 32 & 32 \\
\hline TOTAL & $\mathbf{1 . 7 9 8 , 6}$ & $\mathbf{3 5 4 , 6}$ \\
\hline Redução lavagem e sanitização & $\mathbf{8 0} \%$ \\
\hline
\end{tabular}

\subsubsection{Instalação de medidores de vazão setorizados dentro das áreas produtivas}

Embora se tenha implantado os hidrômetros para cada edificação e fábricas, existe a necessidade de se controlar o consumo nas atividades e operações secundárias que ocorrem sem o devido controle. Instalações de equipamentos de medição e controle do consumo é uma das ações indicadas por Matsumura e Mierzwa (2008) quando se refere a busca de melhoria na operação dos sistemas de produção.

Os hidrômetros que atualmente são utilizados são:

- para medição da água extraída do poço profundo: Tecnobrás tipo nsp80, classe metrológica C, vazão nominal de $45 \mathrm{~m}^{3} / \mathrm{h}$;

- para as áreas de consumo em geral: hidrômetros marca LAO de vazões nominais de 5 a $15 \mathrm{~m}^{3} / \mathrm{h}$, classe $B$, conforme a necessidade do setor.

O custo da implantação desses equipamentos podem ser justificados pelo benefício do melhor controle do consumo de água (Figuras 6.32 e 6.33). 

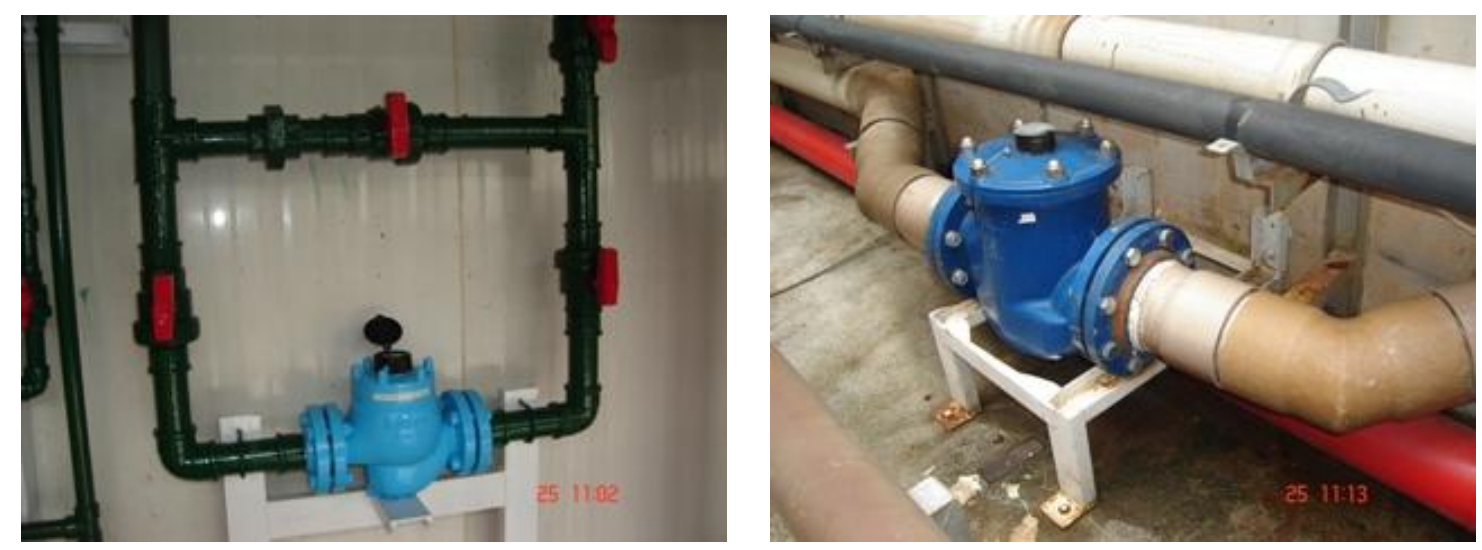

Figura 6.32 - Foto de hidrômetro 1

Figura 6.33 - Foto de hidrômetro 2

\subsubsection{Instalação de sistema de limpeza automatizada "Cleaning in place - CIP"}

Essa proposta é a que possui o maior custo, pois são necessários investimentos importantes em equipamentos e a introdução de instrumentação e controles adequados. Caso se pretenda instalar um sistema CIP em reatores já existentes, grandes modificações devem ser executadas nos mesmos para a implantação dos dispositivos, como instalação de tubulações, alteração de entradas /conexões nos costados ou tampas superiores dos reatores, instalação de válvulas e sistemas de controle automatizados, instalação de tanques auxiliares para produtos de limpeza e agentes sanitizantes, etc.

Uma instalação inteiramente nova está sendo testada na empresa (Fábrica 3), mostrada nas figuras $6.34,6.35,6.36,6.37$ e 6.38 . 


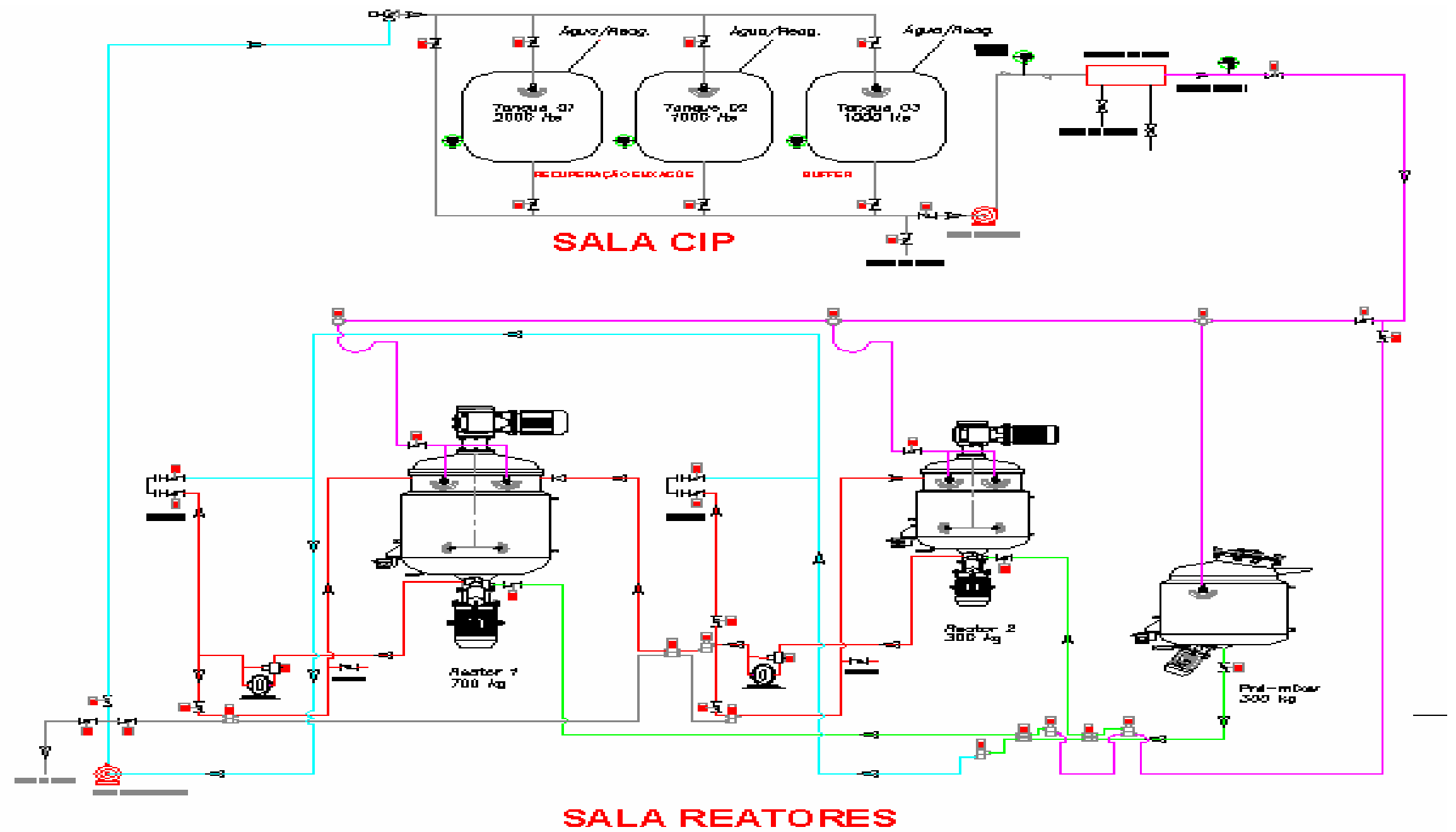

Figura 6.34 - Diagrama do sistema de limpeza CIP 


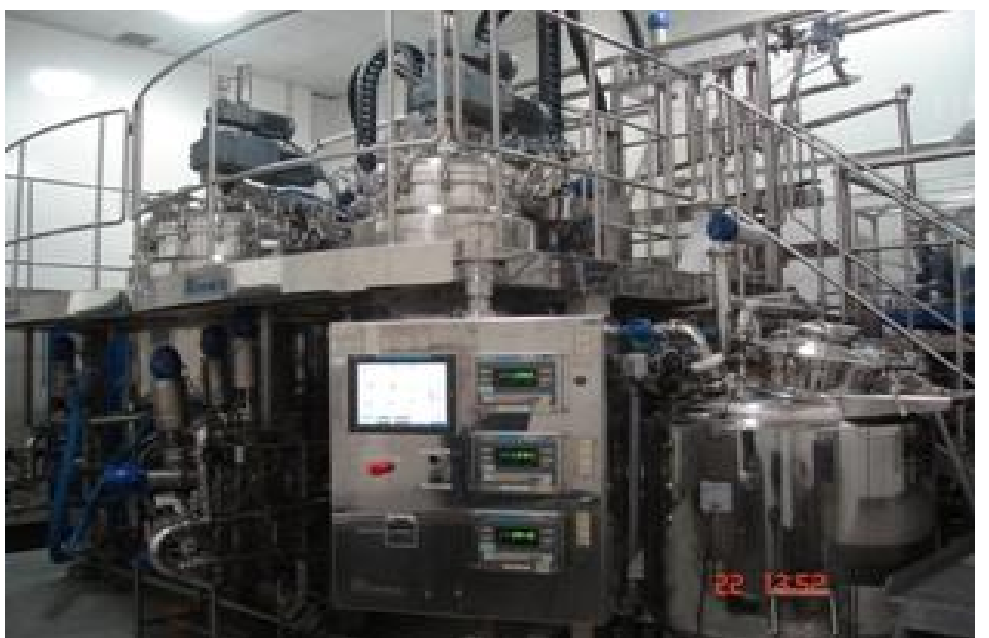

Figura 6.35 - Vista dos reatores Kromix com sistema CIP

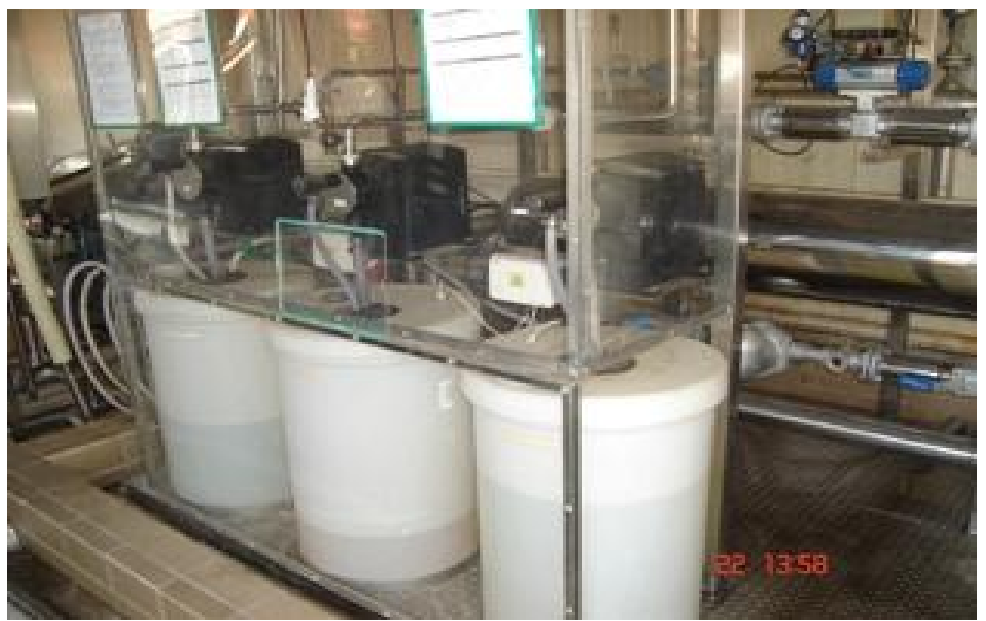

Figura 6.37 - Tanques de reagentes para sistema CIP

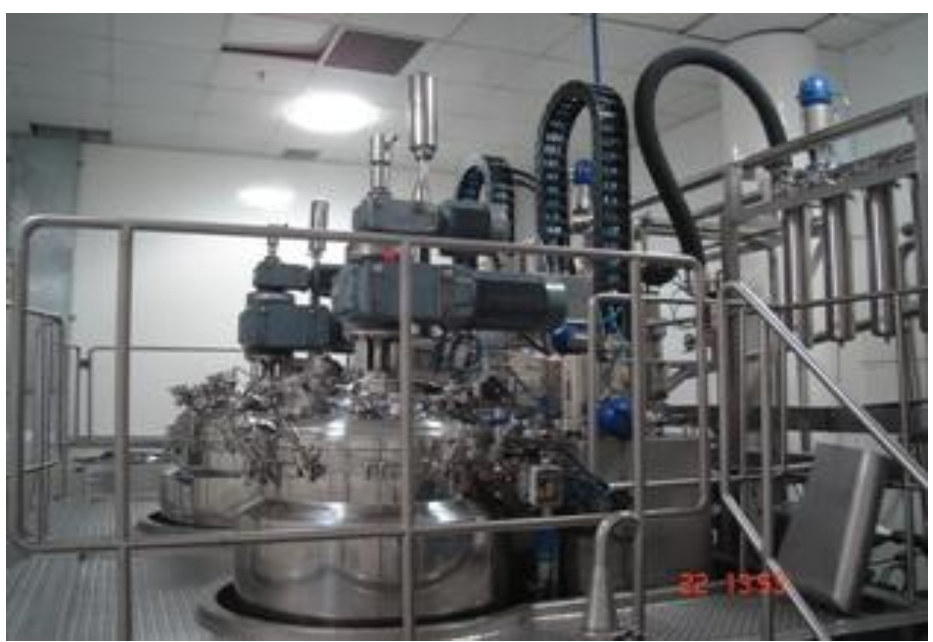

Figura 6.36 - Vista dos reatores Kromix com sistema CIP 2

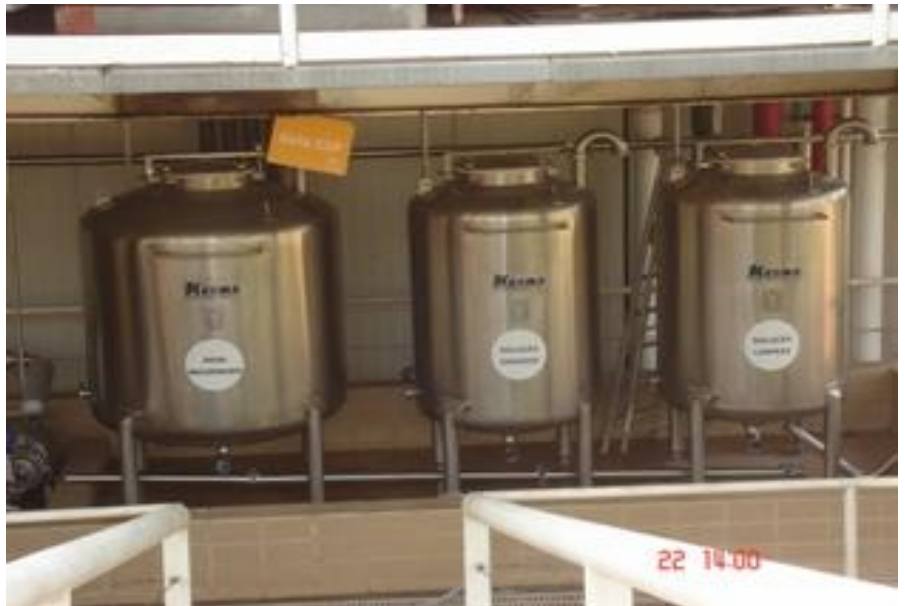

Figura 6.38 - Tanques de recirculação do sistema CIP 
Comparando-se o sistema CIP com a operação de limpeza e sanitização manual, conforme previsão de projeto, deverão ser obtidos os seguintes resultados, colocados nas tabelas 6.15, 6.16 e 6.17 :

Tabela 6.15 - Consumos com limpeza e sanitização com processo manual

\begin{tabular}{lcccc}
\hline \multicolumn{1}{c}{ Consumos } & $\begin{array}{c}\text { pré mixer } \\
\mathbf{3 0 0}\end{array}$ & mixer $\mathbf{3 0 0}$ & mixer $\mathbf{7 0 0}$ & Total \\
\hline Tempo de lavagem (h) & 2,5 & 5 & 8 & 15,5 \\
\hline Água Potável (L) & 800 & 800 & 2.100 & 3.700 \\
\hline Água Purificada (L) & 100 & 150 & 200 & 450 \\
\hline Álcool - sanitização (L) & 80 & 80 & 150 & 310 \\
\hline Óleo mineral (L) & 80 & 80 & 150 & 310 \\
\hline Energia elétrica (kW/h) & 7,5 & 93,8 & 259,6 & 360,9 \\
\hline
\end{tabular}

Tabela 6.16 - Consumos com limpeza e sanitização com processo CIP

\begin{tabular}{lcccc}
\hline \multicolumn{1}{c}{ Consumos } & $\begin{array}{c}\text { pré mixer } \\
\mathbf{3 0 0}\end{array}$ & mixer $\mathbf{3 0 0}$ & mixer 700 & Total \\
\hline Tempo de lavagem (h) & 2,5 & 2,5 & 3,5 & 8,5 \\
\hline Água Potável (L) & 650 & 650 & 1.650 & 2.950 \\
\hline Água Purificada (L) & 200 & 200 & 600 & 1.000 \\
\hline Álcool - sanitização (L) & --- & --- & --- & --- \\
\hline Óleo mineral (L) & --- & --- & --- & --- \\
\hline Energia elétrica (kW/h) & 7,5 & 46,9 & 113,6 & 168,0 \\
\hline
\end{tabular}

Tabela 6.17 - Economias previstas com limpeza CIP

\begin{tabular}{lc}
\hline \multicolumn{1}{c}{ Consumos } & $\begin{array}{c}\text { Economias } \\
(\%)\end{array}$ \\
\hline Tempo de lavagem & $46,6 \%$ \\
\hline Água Potável & $20,3 \%$ \\
\hline Água Purificada & $-22,2 \%$ \\
\hline Água Total & $\mathbf{4 , 8 2 \%}$ \\
\hline Energia elétrica $(\mathrm{kW} / \mathrm{h})$ & 53,4 \\
\hline
\end{tabular}

A economia total prevista no consumo de água é de aproximadamente $\mathbf{5 \%}$ porém tem-se muitas outras vantagens que devem ser levadas em conta:

a) Padronização através da automatização dos processos de limpeza e sanitização de equipamentos; 
b) Maior confiabilidade em relação a eficiência do processo em relação às exigências de cGMP - "current Good Manufactoring Practices";

c) Diminuição dos tempos de operação;

d) Diminuição de mão de obra e dos riscos em relação à segurança dos operadores;

e) Eliminação do consumo de álcool e óleo no processo de limpeza e sanitização;

f) Economia de energia elétrica;

\subsection{Considerações sobre a possibilidade de reúso da água tratada já disponível}

A empresa Natura já possui implantado um programa de reúso de água e emprega parte de seus efluentes tratados em diversas aplicações como na lavagem de ruas, lavagem de paredes e edificações, rega de jardins, em lâminas d'água decorativas, uso na rede de combate a incêndio e nos sanitários. O reúso de cerca de $55 \%$ do efluente tratado produzido na ETE para as aplicações acima reforça o conceito descrito por Mancuso e Santos (2003), e que foi estabelecido pelo Conselho Econômico e Social das Nações Unidas (UNITED NATIONS, 1958), que afirma que "nenhuma água de boa qualidade deve ser utilizada para usos que toleram águas de qualidade inferior".

Com o objetivo de avaliar a possibilidade de aplicação dos $45 \%$ restantes de efluente tratado que atualmente são lançados ao Rio Juquery, o que corresponde a cerca de $110 \mathrm{~m}^{3} /$ dia., verificou-se que esses efluentes tratados, embora atendendo totalmente aos requisitos das normas pertinentes para disposição em corpos hídricos (artigo 34 da Resolução CONAMA n³57/2004 e artigos 12 e 18 do Decreto Estadual $\left.n^{\circ} 8468 / 76\right)$, não podem ser utilizados para fins mais nobres, diretamente nos processos produtivos, pois ainda possui contaminantes (cor, odor e sais como 
cloretos) que são incompatíveis com a qualidade requerida da água que deve ser utilizada nas operações de lavagem e sanitização.

Mesmo que tais efluentes tratados passassem por um tratamento complementar, como por exemplo utilizando-se osmose reversa, que elevasse suas características aos padrões de qualidade exigidos nos processos de fabricação de cosméticos, a falta de legislação específica regulando tal aplicação, impede a autorização de seu uso pelos orgãos de vigilância sanitária.

Foram avaliadas as possibilidades de uso em outras aplicações, especialmente em processos auxiliares como em torres de resfriamento nas fábricas, sistemas de ar condicionado e selos hidráulicos de bombas de vácuo. Entretanto essas aplicações são, no momento, inviáveis pelos seguintes motivos:

1. As torres de refrigeração que são utilizadas nas fábricas para refrigeração de pequenos compressores, são apenas 5 e de pequena capacidade de armazenamento (340 L) e circulação de água (Figuras 6.39 e 6.40), sendo a reposição da água perdida por evaporação no processo de resfriamento realizada por bóia na bacia de recolhimento. Os dados de consumo indicam uma reposição de cerca de 300 L/dia.

Com um consumo tão pequeno, do ponto de vista econômico tal aplicação não encontra justificativa para que sejam adotados sistemas de troca iônica ou mesmo osmose reversa que condicionem a água ao nível de qualidade necessário.

2. O sistema de ar condicionado de toda a empresa utiliza água gelada (circuito fechado) produzida em central com "chillers" cujos condensadores são refrigerados a ar, portanto não necessitando de água em torres de refrigeração (Figuras 6.41 e 6.42).

3. As bombas de vácuo podem utilizar essa água efluente tratada porém, considerando o alto teor de cloretos, poderia levar à corrosão de componentes das bombas e a danos. Essas bombas utilizam relativamente pouca água de reposição (de 25 a 35 L/h 
para o reator de $7.000 \mathrm{~L}$ ). Considerando todas as bombas de vácuo esse consumo não chega a $5 \mathrm{~m}^{3} /$ dia, também não justificando o investimento necessário em tubulações de distribuição de água, além do risco de danos por corrosão, caso essa água não passe por um tratamento prévio.

Assim enquanto não se obtiver um efluente tratado com melhores características não se pode recomendar tal aplicação. Um processo para melhorar essas características seria o uso de colunas de troca iônica ou mesmo osmose reversa, que eliminaria sais evitando corrosão e depósitos indesejáveis, porém a um custo elevado que não encontra justificativa atualmente.

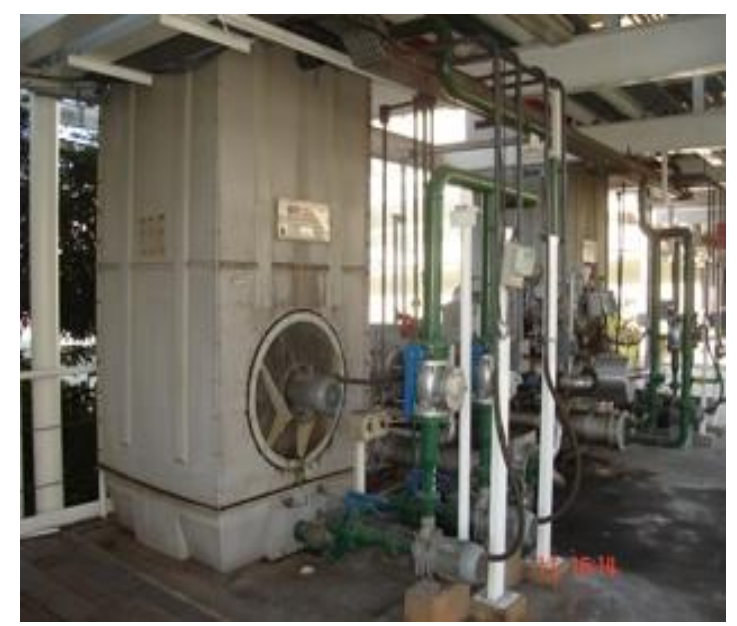

Figura 6.39 - Torre de refrigeração 1

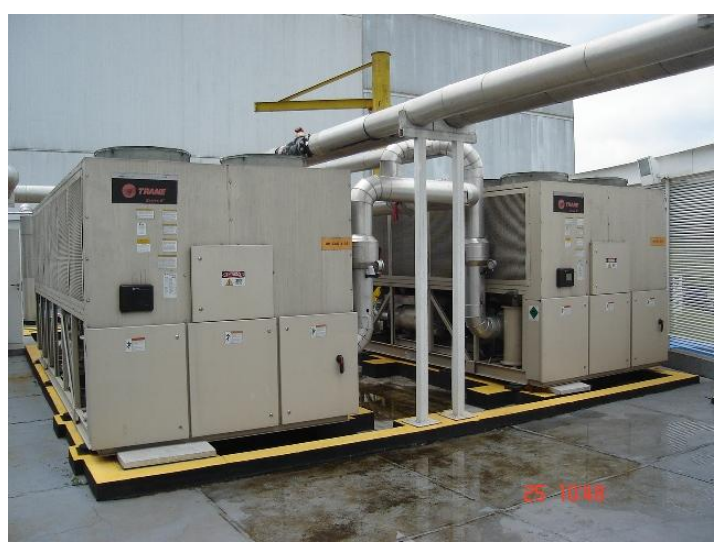

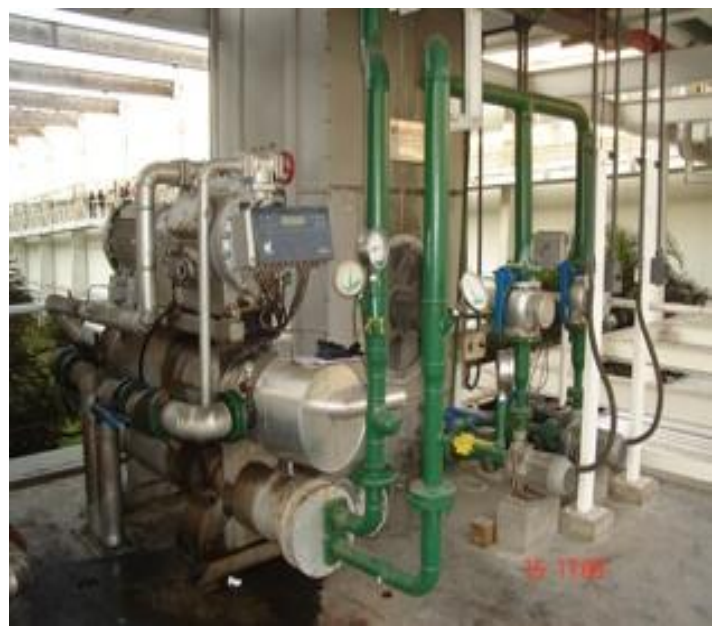

Figura 6.40 - Torre de refrigeração 2

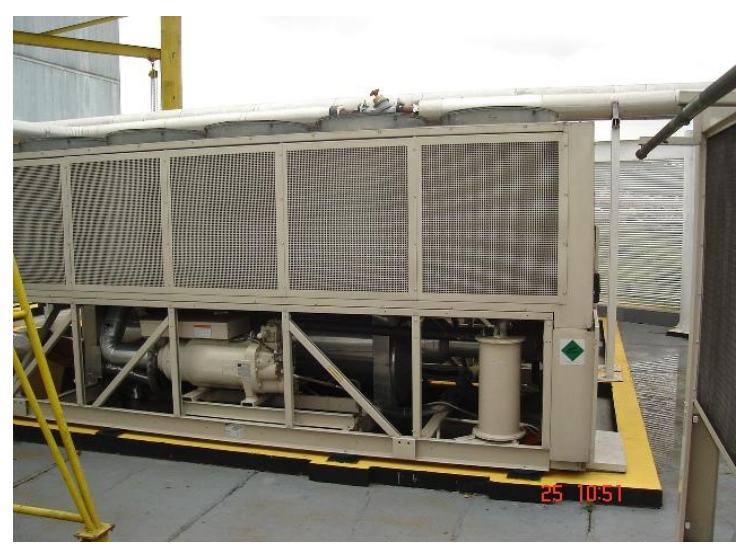

Figura 6.41 - Chillers ar condicionado 1 Figura 6.42 - Chillers ar condicionado 2 


\section{CONCLUSÕES}

Em função da necessidade de água de boa qualidade (potável ou superior), não é possível o reúso direto de água proveniente da ETE nas operações de limpeza e sanitização de equipamentos do processo de produção. Isso somente será possivel caso esse efluente tratado passe por um tratamento complementar, adequando suas características a aplicações mais nobres. De qualquer modo, ainda é necessária a regulamentação de leis que permitam, com a devida segurança e levando-se em conta os conceitos de Vigilância Sanitária e Saúde Pública, que águas provenientes de efluentes tratados possam ser utilizadas para essas finalidades.

As atividades com maior consumo de água são as relativas à limpeza e sanitização de reatores de fabricação, tanques de armazenamento e tubulações, que correspondem a cerca de $69 \%$ do consumo na Fábrica 2. Essas operações são também as maiores geradoras de efluentes industriais.

O estudo realizado na Fábrica 2 mostrou que é possível economias de até $80 \%$ nessas atividades de limpeza e sanitização.

Também o estudo de remonte de lotes na Fábrica 2 mostrou a possibilidade de economias no consumo de água de até 63 \% com a eliminação de até 2 lavagens intermediárias entre lotes de fabricação nos reatores.

Esses estudos, se aplicados às Fábricas 1 e 3, certamente evidenciarão economias importantes no consumo de água, com o uso dos mesmos conceitos utilizados para a Fábrica 2.

Isto é possível, utilizando:

1. procedimentos padronizados de operação;

2. programas de treinamento e conscientização de operadores; e

3. introdução de novos procedimentos tais como o remonte de lotes de fabricação, reduzindo o número de operações de limpeza e sanitização de equipamentos. 
$\mathrm{Na}$ Fábrica 3, embora ainda em fase de testes, espera-se diminuir o consumo de água através da utilização de processo CIP - "cleaning in place", prevendo-se uma economia de 4,8\%, além dos outros benefícios típicos desse sistema que são: a garantia da padronização da operação de limpeza de reatores, diminuição do tempo de operação, menor consumo de energia e menor desgaste e risco aos operadores. 


\section{REFERÊNCIAS}

ALVAREZ, D. et al. Minimization-optimization of water use in the process of cleaning reactors and containers in a chemical industry. Journal of Cleaner Production, $n$. 12, p. 781-787, 2004.

ASANO, T. et al. Wastewater reclamation and reuse. Lancaster: Technomic Publishing, 1998. $1528 \mathrm{p}$.

BRAGA, B. et al. Introdução à engenharia ambiental, 2. ed. São Paulo: Ed. Pearson-Prentice Hall, 2005. 318 p.

BRASIL. ANA - Agência Nacional de Águas. Disponibilidade e demandas de recursos hídricos no Brasil, Brasília: 2005, 134 p.

. ANA - Agência Nacional de Águas. Conjuntura dos recursos hídricos no Brasil, Brasília: 2009, 204 p.

ANVISA - Agência Nacional Vigilância Sanitária. Portaria 348 de 18 de agosto de 1997. Institui o Manual de Boas Práticas de Fabricação e o Roteiro de Inspeção para indústrias de Produtos de Higiene Pessoal, Cosméticos e Perfumes. Diário Oficial da República Federativa do Brasil, Poder Executivo, Brasília, DF, 19 ago 1997.

. CONAMA - Conselho Nacional do Meio Ambiente. Resolução n. 357 de 17 de março de 2005. Dispõe sobre a classificação dos corpos de água e diretrizes ambientais para o seu enquadramento, bem como estabelece as condições e padrões de lançamento de efluentes, e dá outras providências. Diário Oficial da República Federativa do Brasil, Poder Executivo, Brasília, DF, 18 mar. 2005. Seção 1, p. 58-63.

CPDS - Comissão de Política de Desenvolvimento Sustentável. Agenda 21 brasileira: ações prioritárias. 2. ed. Brasília: Ministério do Meio Ambiente, 2004. 158 p.

. ISA - Instituto Sócio Ambiental. Consumo e perda de água na cidade de São Paulo. São Paulo: 2007. 
. Ministério da Saúde. Portaria 518 de 24 de março de 2004. Estabelece os procedimentos e responsabilidades relativos ao controle e vigilância da qualidade da água para o consumo humano e seu padrão de potabilidade .... Diário Oficial da República Federativa do Brasil, Poder Executivo, Brasília, DF, 26 mar. 2004. Seção 1, p. 266-270.

CUNHA, O. A. A. Água desmineralizada para indústria cosmética. Cosmetics \& Toiletries, v. 3, p. 22-28, 1991.

DAEE - Departamento de Águas e Energia Elétrica, Plano estadual de recursos hídricos: 2004/2007 resumo, São Paulo, 2006, 92 p.

DVARIONIENE, J.; STASISKIENE, Z. Integrated water resources management model for process industry in Lithuania. Journal of Cleaner Production, n. 15, p. 950-957, 2007.

ESTADOS UNIDOS. EPA - Environmental Protection Agency. Guidelines for water reuse. Washington: 2004. 478 p. (EPA/625/R-04/108).

. U. S. Pharmacopeia. The United States Pharmacopeial Convention, 30 ed., mai 2007, Rockville: 2007. 4134 p.

FONTANA JR., A. Água para uso na fabricação de cosméticos. Atualidade Cosmética, v.8, n. 49, p. 94-98, 2001.

HARDIN, G. The tragedy of the commons. Science, v. 162, p.1243-1248,1968.

HESPANHOL, I. Esgotos como recurso hídrico -Parte I: Dimensões políticas, institucionais, legais, econômico-financeiras e socioculturais, Engenharia, Instituto de Engenharia de São Paulo, n. 523, ano 55, São Paulo, 1997.

HOINKIS, J.; PANTEN, V. Wasterwater recycling in laundries - from pilot to large scale plant. Chemical Engineering and Processing, n. 47, p. 1159-1164, 2008.

HUERTAS, E. et al. Key objectives for water reuses concepts. Desalination, n. 218, p. 120-131, 2008.

KONING, J. et al. Characterisation and assessment of water treatment technologies for reuse. Desalination, n. 218, p. 92-104, 2008. 
MANCUSO, P. C. S.; SANTOS, H. F. Reúso de água. São Paulo: Ed. Manole, 2003. $580 \mathrm{p}$.

MATSUMURA, E. M.; MIERZWA, J. C. Water conservation and reuse in poultry processing plant - a case study. Resources Conservation \& Recycling n. 52, p. 835-842, 2008.

MIERZWA, J. C. Perspectivas Tecnológicas para Tratamento de Água e Efluentes. Revista da Fundação de Apoio à Tecnologia, n. 3, p. 34-37, 2005.

MIERZWA, J. C. O uso racional e o reúso como ferramentas para o gerenciamento de águas e efluentes na indústria - estudo de caso da Kodak Brasileira. 2002. 399 p. Tese (Doutorado) - Escola Politécnica, Universidade de São Paulo, São Paulo, 2002.

MIERZWA, J. C.; HESPANHOL, I. Água na indústria - uso racional e reúso. São Paulo: Oficina de Textos, 2005. 144 p.

METCALF \& EDDY. Wastewater engineering: treatment and reuse. 4. ed., Boston: McGraw-Hill, 2003, 1819 p.

NATURA. Relatório anual 2007, São Paulo, 2008, 126 p.

PHILIPPI JR, A. et al. Saneamento, saúde e ambiente: fundamentos para um desenvolvimento sustentável. São Paulo: Ed. Manole, 2005, 842 p.

REBOUÇAS, A. C. et al. Águas doces no Brasil: capital ecológico, uso e conservação. 3. ed., São Paulo: Escrituras Editora, 2006, 748 p.

SÃO PAULO. (ESTADO). Decreto n. 8.468 de 8 de setembro de 1976. Aprova o Regulamento 997 de 31 de maio de 1976, que dispõe sobre a Prevenção e o Controle da Poluição do Meio Ambiente. Diário Oficial do Estado de São Paulo, São Paulo, 9 set 1976. SABESP - Companhia de Saneamento Básico do Estado de São Paulo, Relatório de sustentabilidade 2007, 2008. 
SARKAR, B. et al. Wastewater treatment in dairy industries - possibility of reuse. Desalination, n. 195, p. 141-152, 2006.

SCHNEIDER, R. P.; TSUTIYA, M. T. Membranas filtrantes para o tratamento de água, esgoto e água de reúso. Associação Brasileira de Engenharia Sanitária, São Paulo, 2001, 234 p.

SCHUELLER, R.; ROMANOWSKI, P. Iniciação à química cosmética. São Paulo: Tecnopress, 2001, $68 \mathrm{p}$.

TOZE, S. Water reuse and health risks - real vs. perceived. Desalination n. 186, p. 41-51, 2006.

TUNDISI, J. G. Novas perspectivas para a gestão de recursos hídricos. Revista USP, n. 70, p. 24-35, 2006.

UNITED NATIONS. Water for industrial use, Economic and social council, Report E/3058STECA/50, United Nations, New York, 1958.

VON SPERLING, M. Introdução à qualidade das águas e ao tratamento de esgotos: princípios do tratamento biológico de águas residuárias. 3. ed., Belo Horizonte: Ed. UFMG, 2005, 452 p.

WILKINSON, J. B.; MOORE, R. J. Cosmetologia de Harry. Madrid: Ediciones Diaz de Santos, 1990, $1039 \mathrm{p}$.

WCED. Our common future. Oxford University Press, World Commission on Environmental and Development, Oxford, 1987.

WHO. Guidelines for drinking-water quality. 3. ed., v. 1, World Health Organization, Genebra, 2008, 668 p.

WHO. Guidelines for the safe use for wastewater, excreta and graywater. v. 1, 3. ed., World Health Organization, Genebra, 2006, 144 p.

YOU, S. et al. A case study on the wastewater reclamation and reuse in the semicondutor industry. Resources, conservation and recycling, n. 32, p. 73-81, 2001. 
ZOTTER, K. "End-of-pipe" versus "process-integrated" water conservation solutions: a comparison of planning, implementation and operating phases. Journal of Cleaner Production, n. 12, p. 685-695, 2004. 